INTERNATIONAL MONETARY FUND

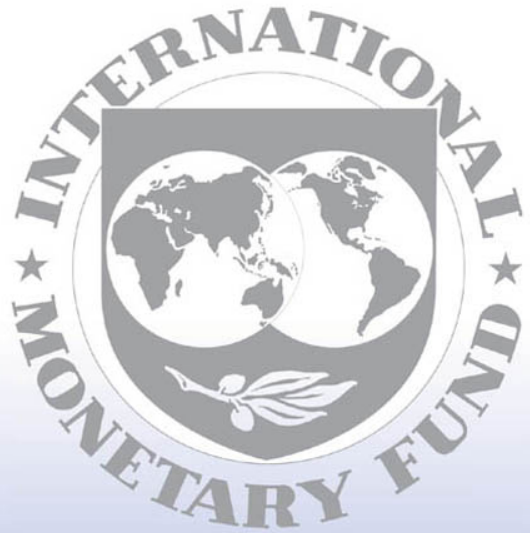

Staff

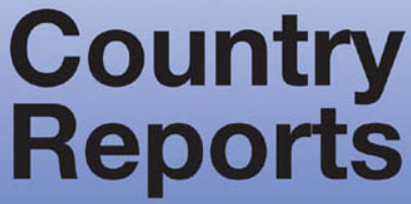




\section{Islamic Republic of Afghanistan: 2007 Article IV Consultation and Third Review Under the Three-Year Arrangement Under the Poverty Reduction and Growth Facility, and Request for Waiver of Performance Criterion-Staff Report; Staff Statement; Public Information Notice and Press Release on the Executive Board Discussion; and Statement by the Executive Director for Islamic Republic of Afghanistan}

Under Article IV of the IMF's Articles of Agreement, the IMF holds bilateral discussions with members, usually every year. In the context of a combined discussion of the 2007 Article IV consultation with Islamic Republic of Afghanistan and third review under the three-year arrangement under the Poverty Reduction and Growth Facility, and request for a waiver of a performance criterion, the following documents have been released and are included in this package:

- $\quad$ The staff report for the 2007 Article IV consultation, Third Review Under the Three-Year Arrangement Under the Poverty Reduction and Growth Facility, and Request for Waiver of Performance Criterion, prepared by a staff team of the IMF, following discussions that ended on November 15, 2007, with the officials of Islamic Republic of Afghanistan on economic developments and policies. Based on information available at the time of these discussions, the staff report was completed on January 28,2008 . The views expressed in the staff report are those of the staff team and do not necessarily reflect the views of the Executive Board of the IMF.

- A staff statement of February 7, 2008 updating information on recent developments.

- $\quad$ A Public Information Notice (PIN) and Press release summarizing the views of the Executive Board as expressed during its February 13, 2008 discussion of the staff report on issues related to the Article IV consultation and the IMF arrangement, respectively.

- A statement by the Executive Director for Islamic Republic of Afghanistan.

The document listed below have been or will be separately released.

Letter of Intent sent to the IMF by the authorities of Islamic Republic of Afghanistan*

Memorandum of Economic and Financial Policies* by the authorities of Islamic Republic of Afghanistan*

Poverty Reduction Strategy Paper-Progress Report

Selected Issues Paper

Statistical Appendix

Technical Memorandum of Understanding*

*Also included in Staff Report

The policy of publication of staff reports and other documents allows for the deletion of market-sensitive information.

To assist the IMF in evaluating the publication policy, reader comments are invited and may be sent by e-mail to publicationpolicy@imf.org.

Copies of this report are available to the public from International Monetary Fund • Publication Services $70019^{\text {th }}$ Street, N.W. $\bullet$ Washington, D.C. 20431

Telephone: (202) 623-7430 • Telefax: (202) 623-7201

E-mail: publications@imf.org •Internet: http://www.imf.org

Price: $\$ 18.00$ a copy

International Monetary Fund

Washington, D.C. 
This page intentionally left blank 
INTERNATIONAL MONETARY FUND

ISLAMIC REPUBLIC OF AFGHANISTAN

\title{
Staff Report for the 2007 Article IV Consultation, Third Review Under the Three-Year Arrangement Under the Poverty Reduction and Growth Facility, and Request for a Waiver of Performance Criterion
}

\author{
Prepared by the Middle East and Central Asia Department \\ in consultation with other departments
}

Approved by Juan Carlos Di Tata and Anthony R. Boote

January 28, 2008

\begin{abstract}
- $\quad$ Discussions were held in Kabul from October 30-November 15, 2007. The mission met with Senior Minister Arsala; Minister of Finance Ahady; former Governor of Da Afghanistan Bank (DAB) Delawari ${ }^{1}$ Minister of Commerce and Industry Farhang; other government officials; and representatives of Parliament, the diplomatic and donor communities, and the private sector.

- $\quad$ The staff team comprised Mr. Elhage (head), Ms. Farahbaksh, Mr. Wieczorek (all MCD), Mr. Tyson (FAD), Mr. Saxegaard (PDR), Mr. Hayward (MCM expert), and Mr. Charap, Fund resident representative in Kabul.
\end{abstract}

- $\quad$ At the conclusion of the last Article IV consultation on March 6, 2006, Executive Directors noted that Afghanistan continued to face formidable medium-term challenges, compounded by lingering insecurity. Directors stressed the need to consolidate macroeconomic stability while pursuing vigorously the reform agenda in support of sustained growth and poverty alleviation. Since then, the authorities have succeeded in maintaining macroeconomic discipline, but progress on the structural agenda has been uneven and slow. Moreover, rapid growth in commercial banking has given rise to new challenges and risks.

- $\quad$ Afghanistan's three-year PRGF arrangement amounting to SDR 81.0 million (50 percent of quota) was approved by the Executive Board in June 2006. The arrangement supports the authorities' economic program through March 2009. On July 9, 2007, the Board completed the second review of the program and agreed that Afghanistan had reached the decision point under the enhanced HIPC Initiative. Completion of the third review would allow the fourth disbursement (SDR 11.3 million).

- $\quad$ Afghanistan maintains a managed float regime, with no preannounced path for the exchange rate. Afghanistan continues to avail itself of the transitional arrangements under Article XIV, but based on available information, no exchange restrictions and/or multiple currency practices are currently in place.

\footnotetext{
${ }^{1}$ On November 17, 2007, Mr. Abdul Qadeer Fitrat was confirmed by Parliament as the new Governor of DAB.
} 
I. Economic Developments: From Postwar Recovery to Macro-Stability ............................. $\underline{6}$

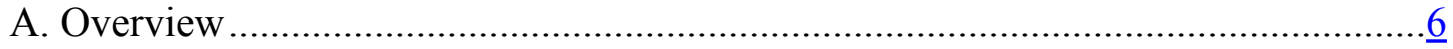

B. Macroeconomic Policies and Debt Issues ........................................................

C. Financial Sector Developments and Risks .................................................. $\frac{13}{13}$

D. Structural Reforms, ANDS (PRSP), and AML/CFT .......................................

II. Medium-Term Outlook: Creating Conditions for Sustainable Growth ..........................17

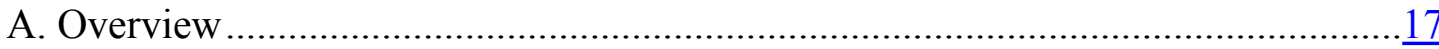

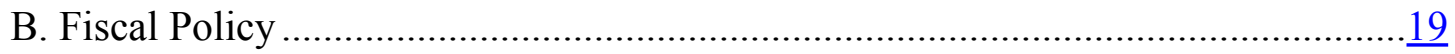

C. Monetary Policy ......................................................................................... $\frac{20}{20}$

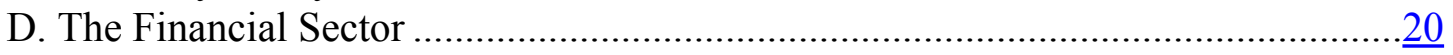

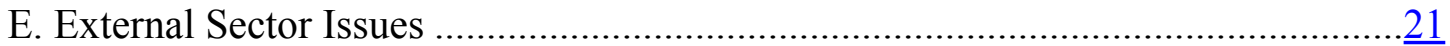

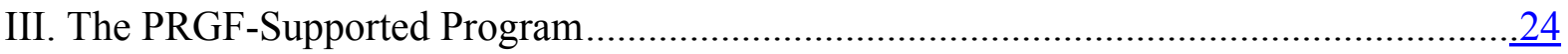

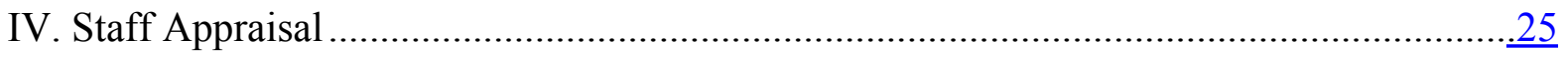

Text Boxes

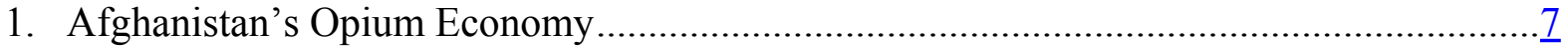

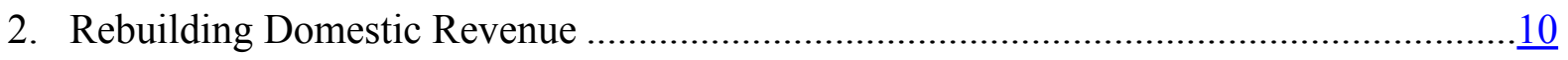

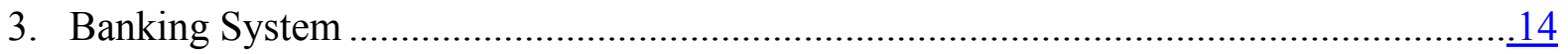

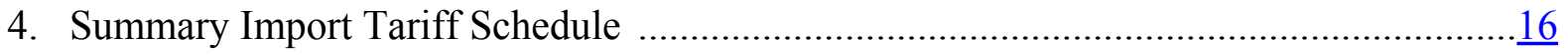

5. Macroeconomic Effects of Donor Assistance......................................................... 18

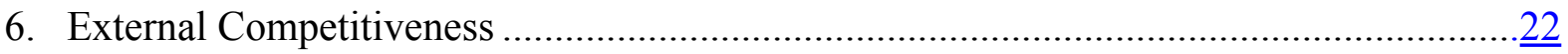

Figures

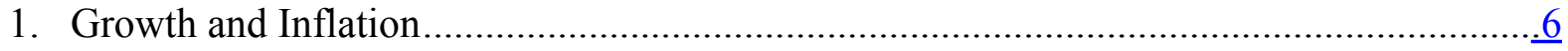

2. Fiscal Balance, 2003/04-2007/08 ….................................................................

3. A Challenging Expenditure Structure Dependent on Donor Funding, 2007/08 ................ $\underline{9}$

4. Monetary Policy Indicators, 2002/03-2007/08 .............................................................11

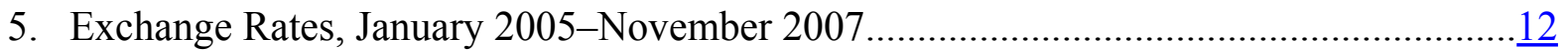

6. Share of Exports of Goods and Services, 2002/03-2006/07 ........................................23

7. Exchange Rates and Ratio of Nontradable to Tradable Prices,

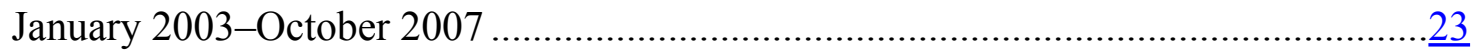

8a. Currency in Circulation, 2005/06-2007/08 …..........................................................

8b. Capital Note Actions, September 2004-October 2007 .................................................28

9a. DAB's Foreign Exchange Reserves, March 2005-October 2007 ..................................29

9b. Price and Exchange Rate Indices, March 2004-November 2007 .................................29 
Tables

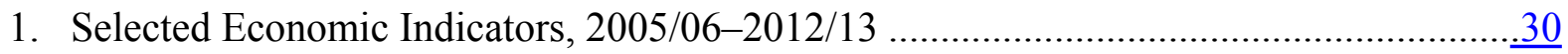

2a. Core Budget, 2005/06-2012/13 (In millions of Afghanis) .............................................

2b. Core Budget, 2005/06-2012/13 (In percent of GDP) ..................................................

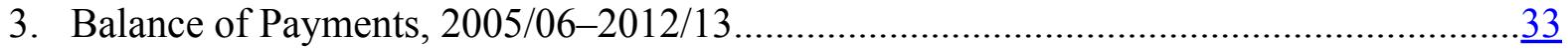

4. Monetary Program (Da Afghanistan Bank), 2005/06-2008/09........................................34

5. External Financing Requirement and Sources, 2005/06-2012/13 ...............................

6. Projected Payments to the Fund as November 30, 2007 .............................................36

7. Proposed Schedule of Reviews and Disbursements .................................................

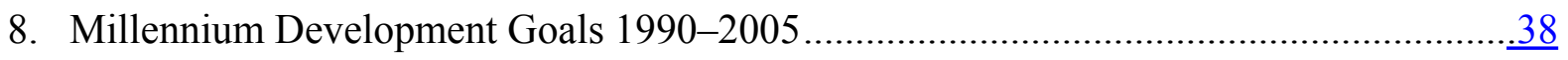

\section{Attachments}

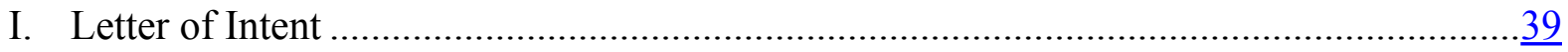

II. Memorandum of Economic and Financial Policies ................................................... 41

III. Technical Memorandum of Understanding ...................................................... 60 


\section{LIST OF ACRONYMS}

$\begin{array}{ll}\text { AML } & \text { Anti-Money Laundering } \\ \text { ANDS } & \text { Afghanistan National Development Strategy } \\ \text { CFT } & \text { Combating Financing of Terrorism } \\ \text { CiC } & \text { Currency in Circulation } \\ \text { CN } & \text { Capital Note } \\ \text { CPI } & \text { Consumer Price Index } \\ \text { BRT } & \text { Business Receipts Tax } \\ \text { DAB } & \text { Da Afghanistan Bank } \\ \text { DABM } & \text { Da Afghanistan Breshna Moassesa } \\ \text { DSA } & \text { Debt Sustainability Analysis } \\ \text { FDI } & \text { Foreign Direct Investment } \\ \text { FLGE } & \text { Fuel and Liquid Gas Enterprise } \\ \text { GDP } & \text { Gross Domestic Product } \\ \text { GST } & \text { General Sales Tax } \\ \text { HIPC } & \text { Heavily Indebted Poor Countries } \\ \text { I-ANDS } & \text { Interim Afghanistan National Development Strategy } \\ \text { MCD } & \text { Middle East and Central Asia Department } \\ \text { MDRI } & \text { Multilateral Debt Restructuring Initiative } \\ \text { MEFP } & \text { Memorandum of Economic and Financial Policies } \\ \text { MOF } & \text { Ministry of Finance } \\ \text { MTFF } & \text { Medium-Term Fiscal Framework } \\ \text { NCBF } & \text { Net Central Bank Financing } \\ \text { NIR } & \text { Net International Reserves } \\ \text { OFID } & \text { OPEC Fund for International Development } \\ \text { PFM } & \text { Public Finance Management } \\ \text { PRGF } & \text { Poverty Reduction and Growth Facility } \\ \text { PRSP } & \text { Poverty Reduction Strategy Paper } \\ \text { SOEs } & \text { State-Owned Enterprises } \\ \text { TMU } & \text { Technical Memorandum of Understanding } \\ & \end{array}$




\section{EXECUTIVE SUMMARY}

\section{Economic Developments}

- $\quad$ Economic performance since the fall of the Taliban regime has been strong, and substantial progress has been made toward achieving macroeconomic stability. During 2002/03-2006/07, real GDP growth averaged 15 percent a year and inflation declined markedly. For 2007/08, growth is expected to exceed 13 percent and inflation to return to double digits, mainly as a result of sharp increases in prices of imported fuel and foodstuffs. The nominal exchange rate has remained stable.

- $\quad$ Economic growth over the medium term will depend critically on confronting governance issues, overcoming infrastructure bottlenecks (particularly in the electricity sector), and implementing structural reforms in support of private sector activities. The security situation continues to impact economic activity and the widespread drug economy is undermining the authorities' efforts to broaden economic development.

\section{Policy Issues}

During the consultation discussions, the authorities were in broad agreement with the staff on the following key issues:

- Greater government ownership of the policy framework and an acceleration of structural reform is needed. Better coordination between government ministries and donors would be instrumental in developing a coherent strategy for reform. At the same time, the government should reaffirm its support for the development of a market economy. An acceleration of the reforms under the PRGF-supported program would provide a strong positive signal.

- $\quad$ Revenue mobilization requires further efforts aimed at capacity building and introduction of a broad-based consumption tax, while maintaining a transparent and equitable trade regime.

- $\quad$ The role of capital notes should be expanded to better manage liquidity and improve the effectiveness of monetary policy.

- $\quad$ Bank supervision and the regulatory framework for the financial sector need to be strengthened.

- $\quad$ There are no immediate risks to external stability and the exchange rate level appears broadly in line with fundamentals.

\section{Program for the remainder of 2007/08 and for 2008/09}

- $\quad$ The PRGF-supported arrangement remains on track. Nevertheless, the implementation of structural conditionality was mixed. The authorities have implemented the following prior actions: (i) completion of a special audit of DAB's reserve assets; (ii) appointment of a reputable audit firm to perform an audit of DAB's financial statements for the financial year 2007/08 - both reflecting safeguards assessment concerns; and (iii) elimination of the discretionary application of a 1 percent import duty on selected industrial inputs.

- $\quad$ The program has been strengthened to address the risks emerging from: (i) government involvement in the domestic petroleum market; (ii) potential fiscal drains stemming from the government's relations with public enterprises; and (iii) a weak supervisory and regulatory framework for the banking system, particularly in light of its recent rapid growth. 


\section{ECONOMic Developments: From Postwar Recovery to MaCro-Stability}

\section{A. Overview}

1. Economic developments since the fall of the Taliban regime, at end-2001, have resulted in high real GDP growth and progress toward macroeconomic stability (Table 1). Real GDP growth during 2002/03-06/07 averaged around 15 percent a year. It dropped in 2006/07 owing to drought, but is expected to exceed 13 percent in 2007/08, reflecting a post-drought rebound in agricultural output (Figure 1a). Inflation declined to single-digit levels in 2006/07, but it returned to double-digits in 2007/08 because of sharp increases in the prices of imported fuel and foodstuffs owing to worldwide commodity price pressures and the depreciation of the U.S. dollar (Figure 1b).

Figure 1. Islamic Republic of Afghanistan: Growth and Inflation (In units as indicated)
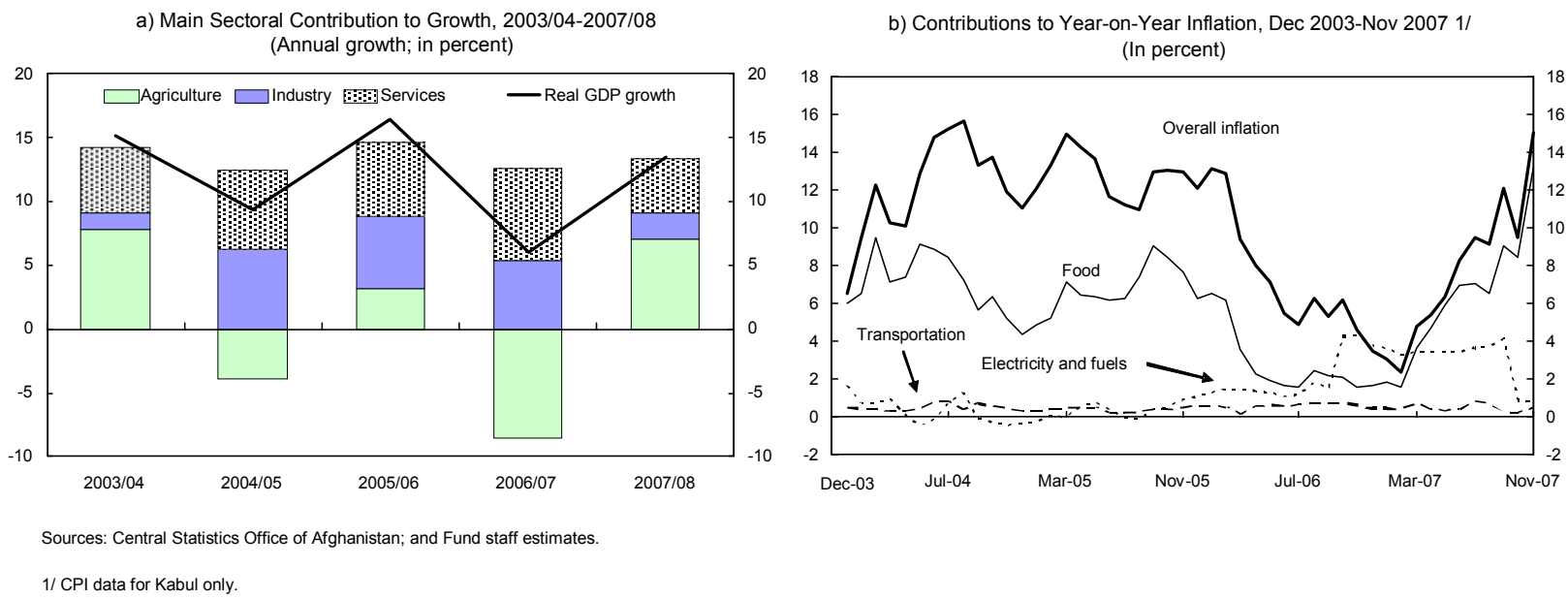

2. Postwar reconstruction, funded by donors, and the return of many skilled and entrepreneurial individuals have stimulated economic activity. Additional impetus came from several large foreign direct investment projects. Nevertheless, the cost of doing business remains high and economic activity is subdued in several areas of critical importance for growth and external sustainability. In particular, no new exports outside the traditional base (carpets, minerals, and horticulture products) have been developed, owing to low capacity, the high cost of capital, and lack of electricity. 


\section{The volatile security situation and the persistence of the drug economy are} weakening attempts at broadening economic development. These two phenomena are intertwined as the resurgence of the Taliban and other anti-government elements is deemed to be fuelled by opium exports. The drug economy (Box 1), while being a source of livelihood for many households, continues to be a major obstacle for Afghanistan to regain its comparative advantage in traditional exports.

\section{Box 1. Afghanistan's Opium Economy}

Opium remains, by far, the largest cash crop in Afghanistan. Opium production has increased steadily from 185 metric tons in 2001 to 8,200 metric tons in 2007. As a result, Afghanistan has become the world's largest opium producer, with its share of the total world supply increasing from 52 percent in 1995 to 93 percent in 2007. The increase in production has resulted in a decline in the farm-gate price of fresh opium at harvest time. Although opium prices declined in 2004-07, they were still three times higher than in 1994-2000. In 2007, about 81 percent of the opium production was located in the south and south-west regions of Afghanistan, where anti-government elements are most active.

The impact of opium cultivation on the economy has been substantial. About 12 percent of the population (or 3.3 million people) were involved in opium poppy cultivation during the 2007 season, with the farm-gate value of the opium harvest amounting to \$1 billion (11 percent of projected licit GDP). The United Nations Office on Drugs and Crime estimates that the total value of the opium harvest (accruing to farmers, laboratory owners, and traffickers) was about $\$ 4$ billion in 2007, compared with $\$ 2.7$ billion in 2005 .
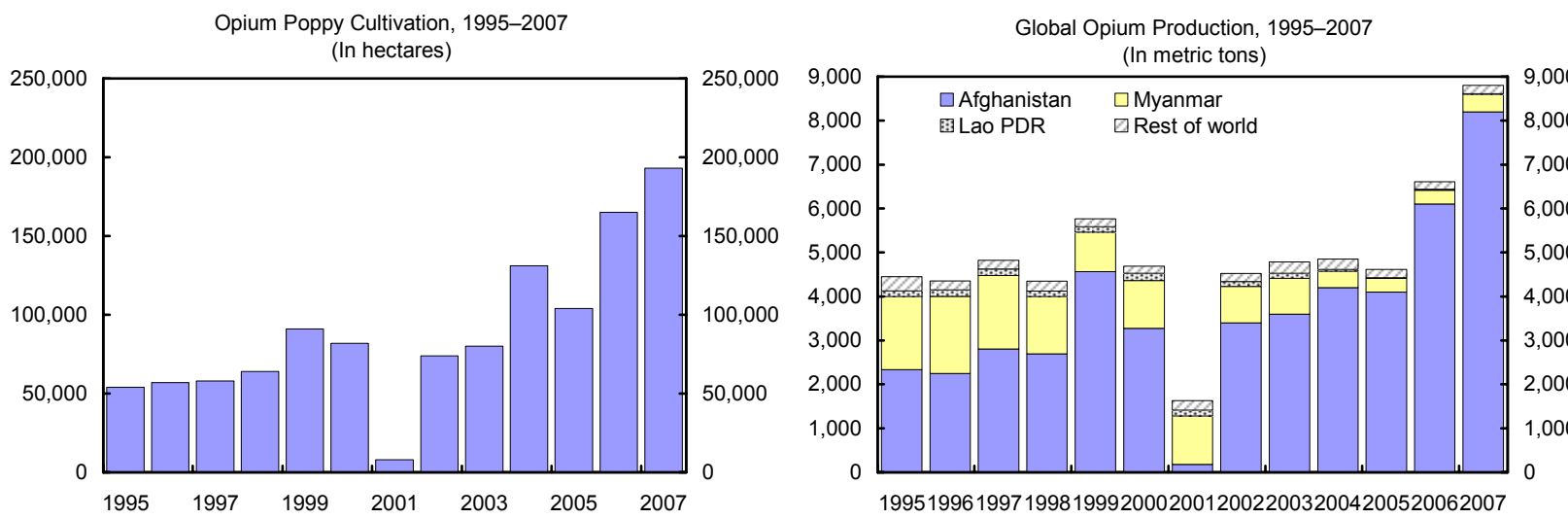

Fresh Opium Farm-gate Prices at Harvest Time, 1995-2007 (In U.S. dollar per kilogram)
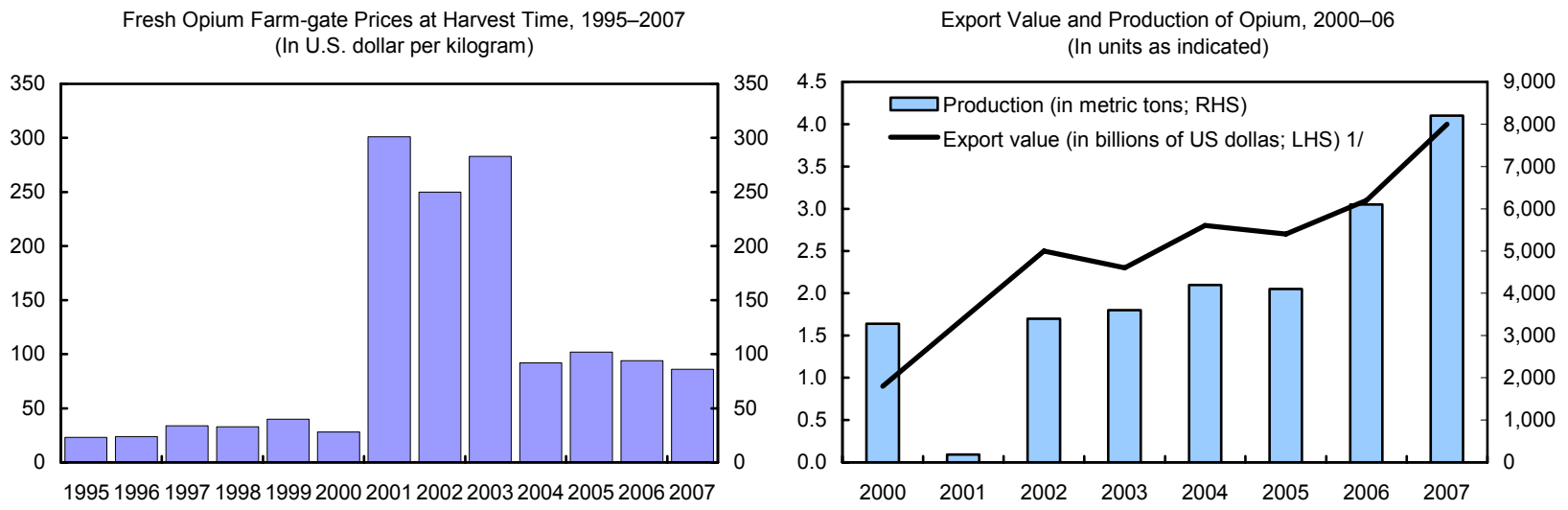

Source: United Nations Office on Drugs and Crime.

1/ Export value for 2001 is not available. 
4. The recommendations of the previous Article IV consultation focused on the need to broaden the revenue base, prepare more realistic development budgets, strengthen the banking system, and establish an enabling environment for private sector activities. The authorities made good progress in key policy areas. They stepped up revenue efforts through tax reforms and capacity building, and strengthened the MediumTerm Fiscal Framework (MTFF), and the implementation of the development budget. They also continued to develop the monetary policy framework and improve banking supervision. With regard to the broader reform agenda, however, policies have been subject to conflicting influences. Proposals favoring interventionist and protectionist measures are currently dominating the domestic economic debate, while the laws critical for private sector development continue to linger in the administrative pipeline and the privatization of stateowned enterprises (SOEs) proceeds at a disappointing pace. At the same time, there have been allegations of corruption and growing frustration with the slow progress on structural reforms.

\section{B. Macroeconomic Policies and Debt Issues}

\section{Despite continued reliance on donor financing for public spending, revenue} efforts have played a central role in improving the underlying fiscal position. Domestic revenues increased markedly from an extremely low base of 4.7 percent of GDP in 2003/04 to 8.2 percent in 2006/07 (Tables 2a and 2b, and Box 2). This increase, combined with a prudent policy toward operating expenditure under the core budget, has led to a gradual reduction in the core operating budget deficit (excluding grants) since 2004/05 (Figure 2). ${ }^{2}$ During the same period, core budget development expenditures grew significantly, still mostly with donor support. However, the bulk of public expenditures, notably outlays on security and development, continue to be undertaken in the context of the external budget (i.e., outside the core budget), which is executed and financed directly by donors (Figure 3 ).

\footnotetext{
${ }^{2}$ The core budget covers operating and development expenditures of the central government.
} 
Figure 2. Islamic Republic of Afghanistan: Fiscal Balance, 2003/04-2007/08 (In percent of GDP)

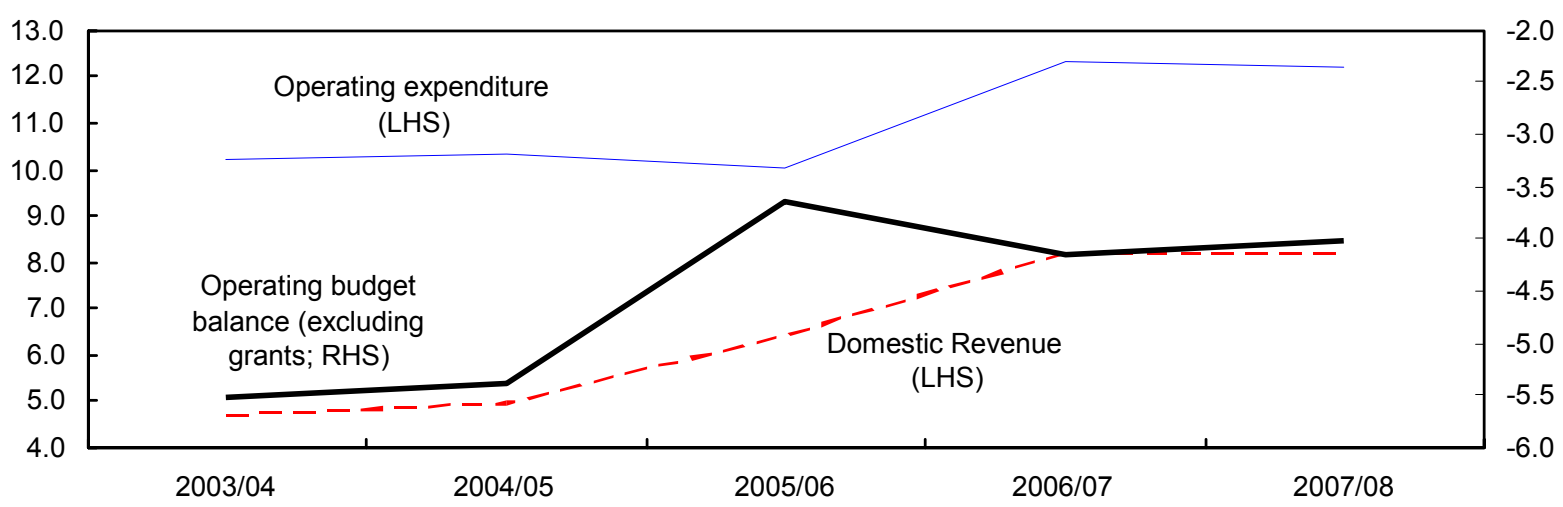

Sources: Ministry of Finance (MoF); Da Afghanistan Bank (DAB); and Fund staff estimates and projections.

Figure 3. Islamic Republic of Afghanistan: A Challenging Expenditure Structure Dependent on Donor Funding, 2007/08

(In percent of GDP)

Type of Expenditure

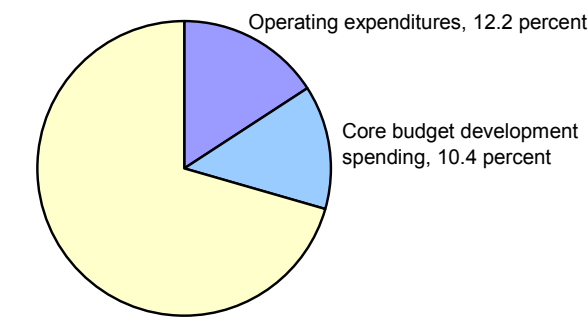

External budget, 54.5 percent
Sources of Funding

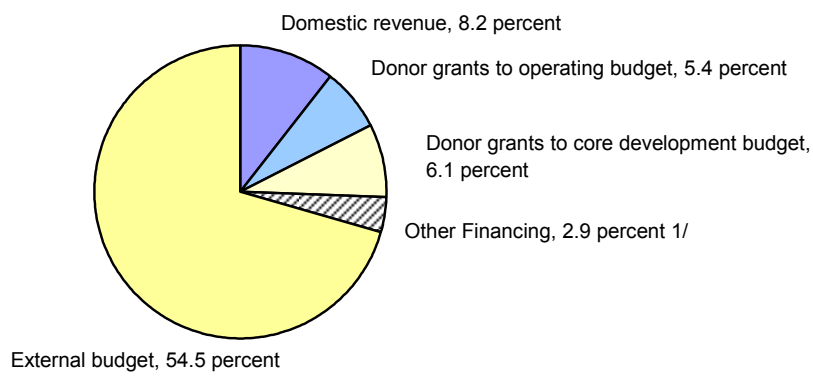

Sources: Ministry of Finance; Da Afghanistan Bank; donors; and Fund staff estimates.

$1 /$ Consists of external loans (50 percent) and use of government deposits (50 percent). 


\section{Box 2. Rebuilding Domestic Revenue}

Key implemented revenue measures include:

- rationalizing the customs schedule;

- simplifying the corporate and personal income tax;

- repealing nuisance taxes; and

- withholding tax on imports, which is creditable against final income tax liabilities.

Steps taken on tax and customs administration include:

- establishing a large taxpayer office (LTO) in the revenue department;

- $\quad$ piloting a medium taxpayer office (MTO) in Kabul; and

- enacting a customs code.

Domestic Revenue

(In millions of Afghanis)

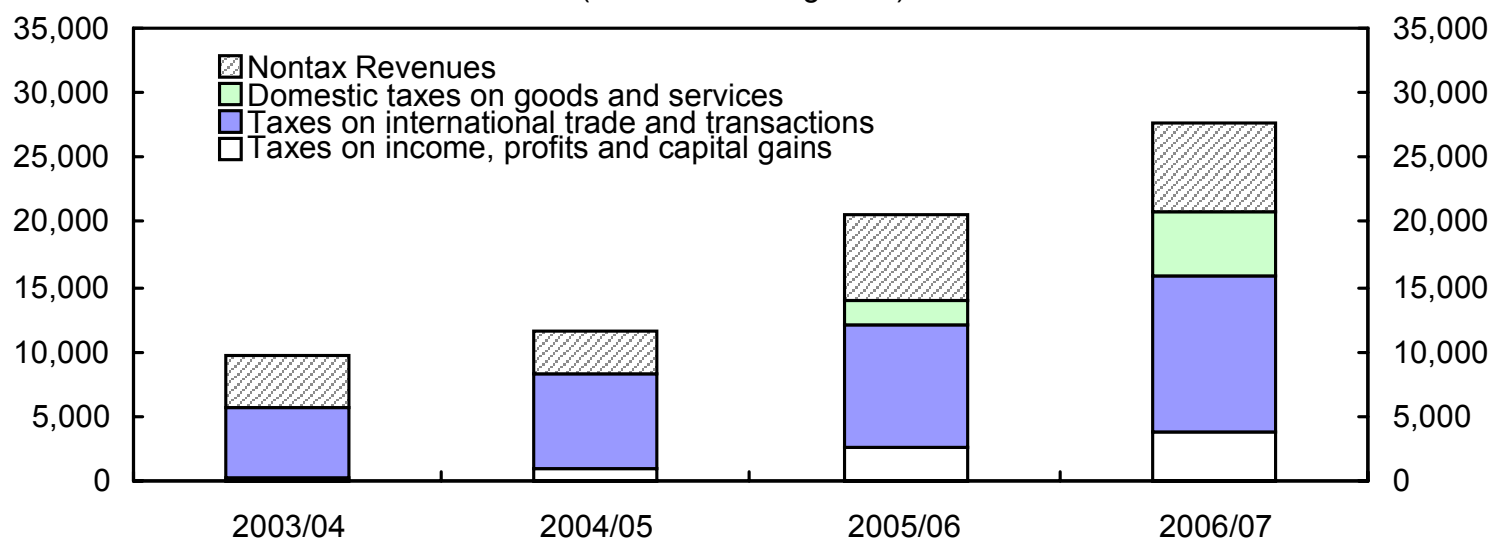

Sources: Ministry of Finance; and Fund staff estimates.

6. The fiscal sector has undergone important reforms over the last few years, but the public finances remain fragile. Reforms have concentrated on: (i) creating a legal framework; (ii) establishing fiscal authority; and (iii) strengthening revenue administration and public financial management (PFM). In 2007/08, the government initiated program budget pilots with a view to consolidating the budget preparation process and facilitating the alignment of expenditures with its priorities under the Afghanistan National Development Strategy (ANDS). Also, the MOF has begun to articulate Afghanistan's medium-term fiscal policy objectives and challenges by using the MTFF. Nevertheless, continued postwar reconstruction needs and escalating security demands are putting pressures on the public finances and perpetuating donor dependence.

\section{Monetary policy management has proved challenging, owing to the high degree} of dollarization and large inflows of foreign exchange. $D A B$ has continued to rely on currency in circulation $(\mathrm{CiC})$ targets and foreign exchange auctions to conduct monetary policy. Following the introduction of a new currency in October 2002, it was assumed that stabilizing the nominal exchange rate would bring about price stability, strengthen the 
demand for Afghanis, and thus reduce dollarization. Inflation, however, turned out to be more persistent than originally expected, due mainly to large inflows of foreign aid and opium export receipts. With ample foreign exchange at its disposal, DAB tightened the $\mathrm{CiC}$ targets and stepped up foreign exchange interventions. In the event, inflation declined (albeit temporarily) to single-digit levels in 2006/07, but "afghanization" has stalled since 2004/05

Figure 4. Islamic Republic of Afghanistan: Monetary Policy Indicators, 2002/03-2007/08
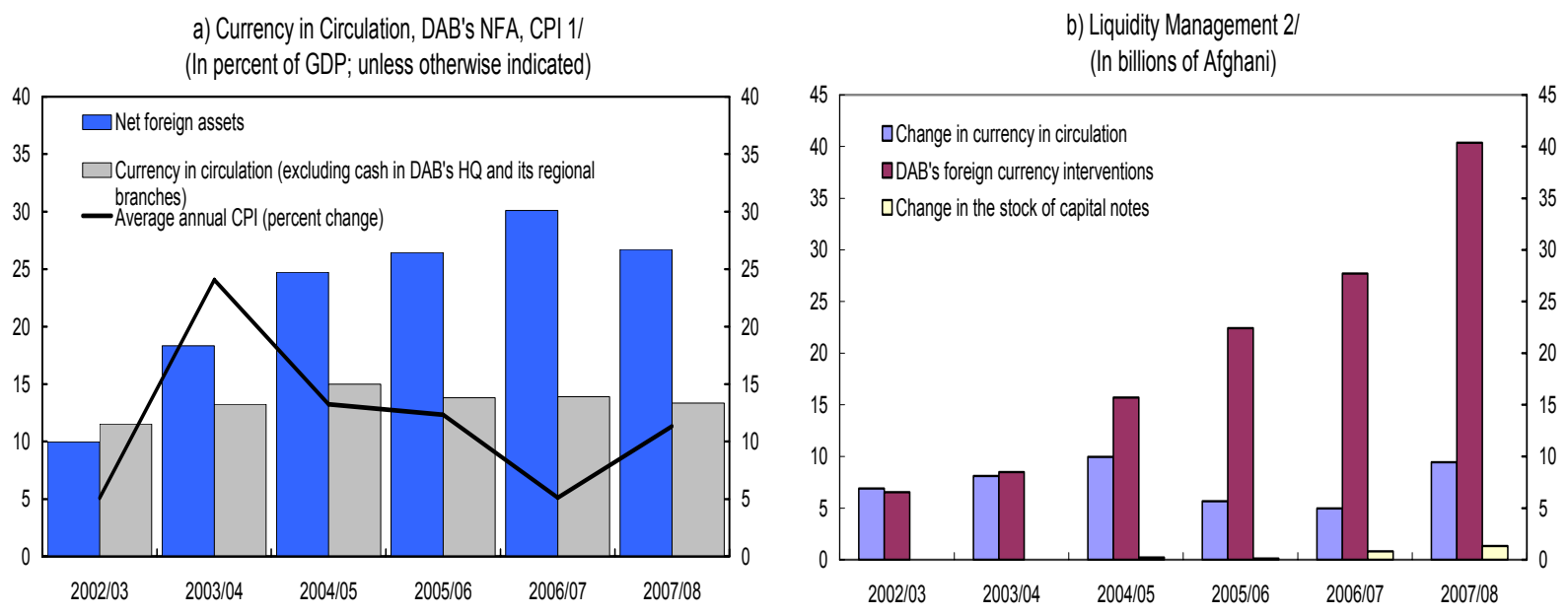

Sources: Da Afghanistan Bank (DAB); Central Statistics Office of Afghanistan; and Fund staff estimates and projections.

1/ For 2007/08, program ceiling for currency in circulation and program projection for NFA and CPI.

2/ For 2007/08: program ceiling for currency in circulation, for other variables: projection based on data through October 2007.

(Figures 4a and 4b). Dollarization, which was originally driven by the increased demand for foreign currencies as a hedge against exchange rate risk, continues to be supported by the abundance of foreign exchange, which strengthened currency substitution, with foreign currencies and Afghanis used interchangeably for domestic transactions. ${ }^{3}$

\section{The rapid development of the banking sector has created an enabling} environment for new monetary policy instruments. In mid-2004/05, DAB launched auctions of capital notes (CNs) with a view to developing them as the primary instrument for monetary policy. Thus far, however, the role of CNs has been limited with the stock outstanding at end-November 2007 not exceeding Af 2 billion (US\$40 million). Interest rates on CNs are negative in real terms, and DAB remains reluctant to expand the volume of the $\mathrm{CN}$ auctions and assume the associated interest cost.

\footnotetext{
${ }^{3}$ For a detailed discussion of this issue see the accompanying selected issues paper "Exchange Rate and the Conduct of Monetary Policy in Afghanistan."
} 
9. Afghanistan's exchange regime continues to fit the definition of a managed float. While the monetary policy conduct resulted in the stability of the Afghani vis-à-vis the U.S. dollar, the authorities have made no commitment to maintaining any particular level of the exchange rate. $\mathrm{DAB}$ has conducted the foreign exchange auctions in a manner consistent with the $\mathrm{CiC}$ targets and sought to smooth short-term fluctuations in the nominal rate only when this has been consistent with the $\mathrm{CiC}$ ceilings under the program. The foreign exchange market is highly decentralized and the spread between the market rate and the auction rate is negligible (Figure 5).

Figure 5. Islamic Republic of Afghanistan: Exchange Rates, Jan 2005-Nov 2007 1/ Auction Cutoff \& Hawala Dealers (DAB); in Afghani per U.S. dollar

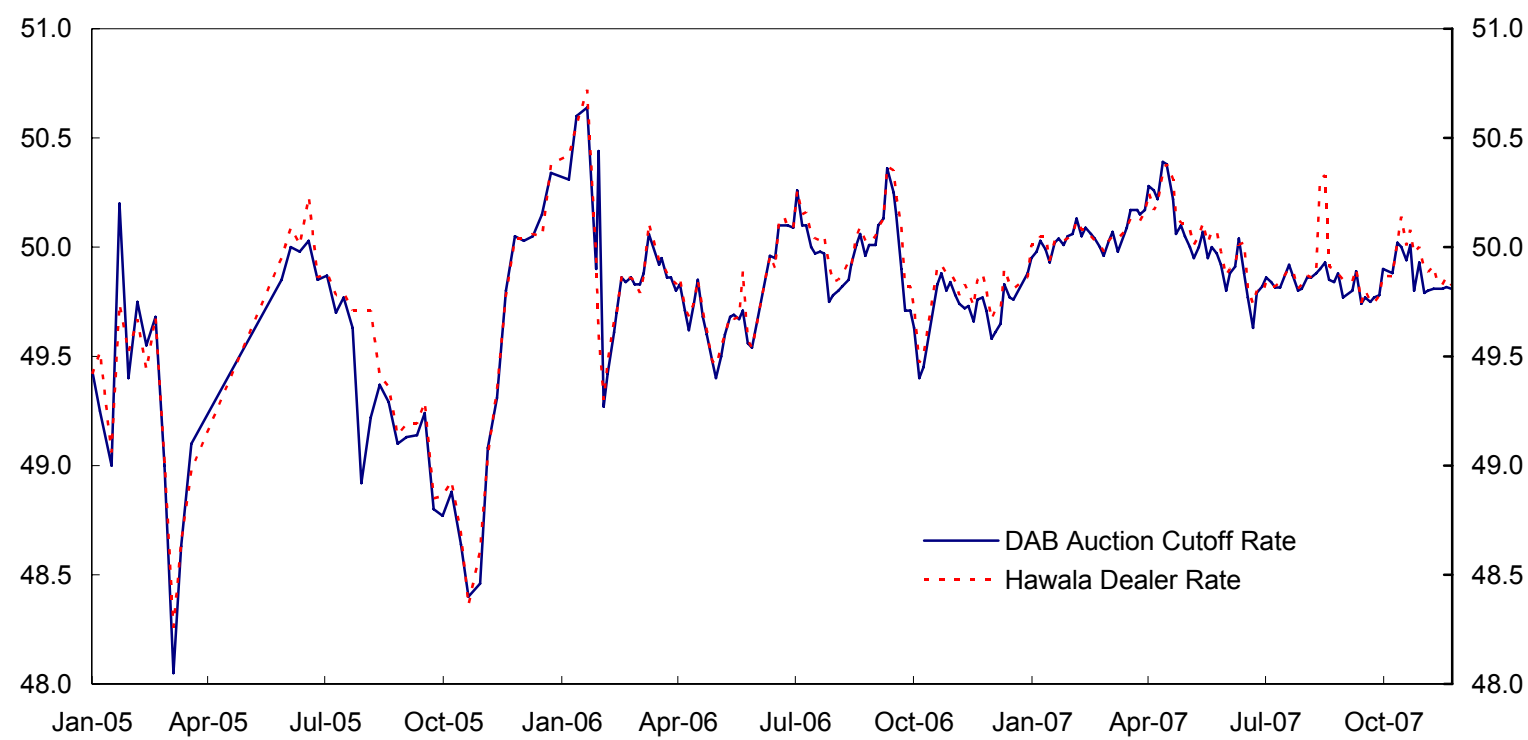

Sources: Afghan authorities; and Fund staff calculations.

1/ Last observation is December 1, 2007.

10. Afghanistan's external position continues to depend on large aid inflows (Table 3). Official transfers increased to 66 percent of GDP in 2006/07 from 53 percent in $2003 / 04$, reflecting mainly higher security spending by donors, with a predominant import content. Large official transfers, foreign direct investment, and debt relief helped improve the import coverage of gross international reserves (excluding imports financed by donors) from 2.8 months of imports in 2002/03 to 9.3 months in 2006/07.

11. Afghanistan's debt sustainability has improved significantly as a result of debt relief from its bilateral creditors and interim debt relief under the HIPC initiative. In July 2006, Paris Club creditors agreed to cancel more than US\$10 billion of debt, thereby reducing Afghanistan's external debt by nearly 90 percent, and capitalized all debt service 
payments falling due until March 31, 2009. ${ }^{4}$ At the HIPC decision point, in July 2007, they committed to cancelling all remaining claims once Afghanistan reaches its completion point under the HIPC initiative. Additional interim debt relief under the HIPC initiative is being provided by the World Bank. The authorities are actively pursuing debt relief agreements with the OPEC Fund for International Development (OFID) and non-Paris Club bilateral and commercial creditors (MEFP $\$ 15$ ), and continue to make progress towards meeting the HIPC completion point triggers (MEFP $\mid 47)$.

\section{Afghanistan still has a high risk of debt distress, notwithstanding significant}

traditional debt relief from bilateral creditors. The Debt Sustainability Analysis (DSA) conducted in the context of the HIPC decision point in July 2007 highlights that Afghanistan's external position is particularly vulnerable to a deterioration in the concessionality of new borrowing and to slower export growth. Nevertheless, full delivery of debt relief under the HIPC initiative and assistance under the Multilateral Debt Relief Initiative (MDRI) would be sufficient to reduce Afghanistan's debt burden indicators to sustainable levels.

\section{Financial Sector Developments and Risks ${ }^{5}$}

\section{Banking sector activities have expanded considerably over the last few years} (Box 3). According to information provided by DAB, as of September 2007, the banking system was well-capitalized (32 percent, compared with the minimum capital adequacy requirement of 12 percent), and the ratio of classified and watch assets to total assets was about 4.6 percent. There are, however, considerable differences among individual banks. In particular, two large private banks that recently experienced significant growth in their loan portfolios have occasionally fallen below the minimum capital adequacy requirement. Also, the low ratio of classified assets to total assets reflects, to some extent, the widespread practice of rolling over loans. In addition, a recent report by DAB on its first full-scale onsite examination of banks indicates that five banks with more than 60 percent of total banking system assets were given a CAMEL rating of 4 , on a $1-5$ scale. $^{6}$ The report reveals serious deficiencies, including a lack of fit and proper management, violations of regulations on connected lending, and significant currency mismatch in some bank.

\footnotetext{
${ }^{4}$ The bilateral agreement with Russia was signed in August 2007.

${ }^{5}$ For a detailed discussion of this topic refer to the accompanying selected issues paper on "Banking Sector developments in Afghanistan."

${ }^{6}$ CAMEL stands for Capital, Asset Quality, Management, Earnings, and Liquidity. The system uses a five points scale for grading each category. An overall composite rating is also assigned based on the same scale, with 1 being the highest rating and 5 the lowest.
} 


\section{Box 3. Banking System}

Afghanistan's banking system has been growing rapidly since the fall of the Taliban regime in 2001. As of end2007, there were 16 licensed banks (compared with 6 banks in 2001), including three state-owned banks and five branches of foreign banks. After a long period of slow growth, the total assets of the banking system more than tripled over the last couple of years, from \$388 million (7 percent of GDP) in March 2005 to \$1.3 billion (about 15 percent of GDP) in September 2007. This increase has been mainly due to the expansion of private banking, whose share of total assets increased from 21 percent to 60 percent. In fact, the assets of two domestic private banks constitute about 50 percent of total banking sector assets. On the liability side, banking sector deposits have grown almost fivefold since March 2005, constituting about 78 percent of the total balance sheet (deposits plus capital) of the banking system as of end-September 2007.

The bulk of activities of the banking sector remains in foreign currencies. As of September 2007, about 77 percent of the total deposits and loans were denominated in U.S. dollars; a proportion slightly higher than in March 2005. Also, all interbank deposits were in non-Afghani currencies, with about 80 percent being denominated in U.S. dollars. About 35 percent of the deposit base of state-owned banks and 55 percent of their loans at endSeptember 2007 were denominated in U.S. dollars, implying a considerable currency mismatch for these banks.
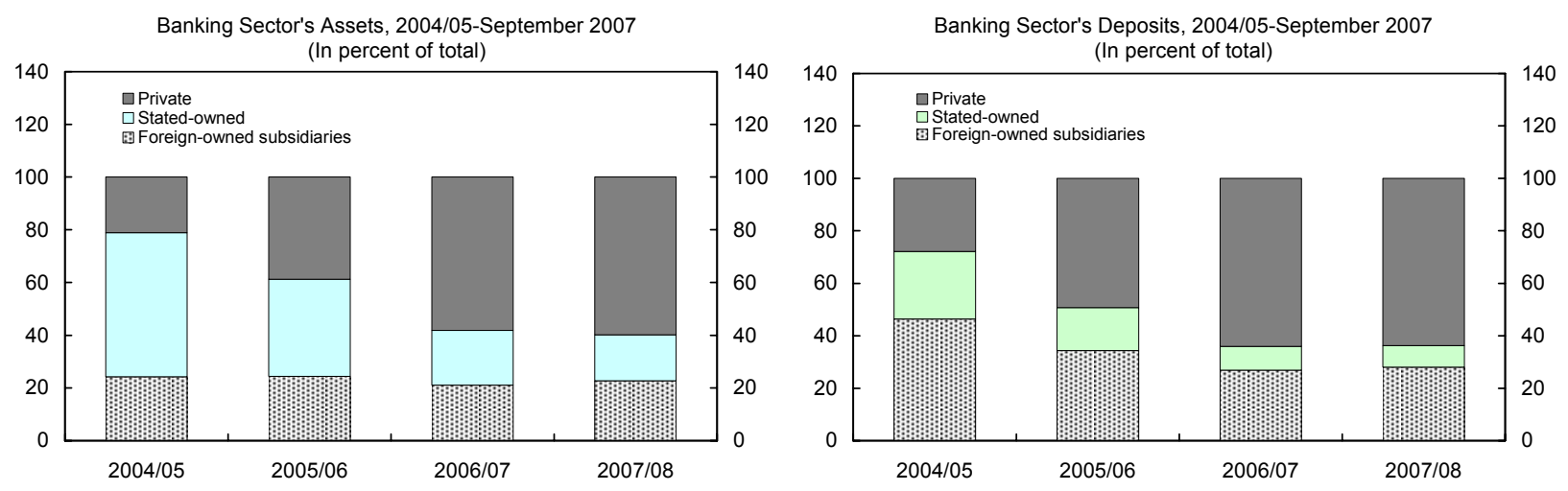

Source: Da Afghanistan Bank (DAB); and Fund staff estimates.

14. The rapid growth in commercial bank activity has prompted DAB to strengthen bank supervision. DAB has recently completed a self-assessment against the Basle Core Principles for Effective Bank Supervision. The assessment yielded a roadmap for addressing weaknesses in DAB's supervisory framework, including noncompliance with the Basle Principles on the management of credit, and on operational and market risks.

\section{Some progress has been made regarding the restructuring of state-owned banks.}

Following the completion of its external audit, Bank Millie has taken a number of steps to restructure and improve its financial status. Moreover, the Cabinet approved the restructuring plan for Bank Pashtany in August 2007, but the audit of its financial statements has not yet been completed. The client accounts of the Export Promotion Bank have been transferred 
to Bank Pashtany, but the merger of the two banks is yet to be finalized. To preserve the value of state-owned banks, the MOF continues to prohibit lending from these banks to enterprises that do not have audited balance sheets and cabinet approved restructuring plans.

\section{Structural Reforms, ANDS (PRSP), and AML/CFT}

16. Structural reforms and the preparation of the legal framework for the business environment have advanced slowly, and the government still plays a major role in key sectors. Little progress has been made in preparing for the restructuring/privatization of government enterprises that are not covered by the law on SOEs and the government has not yet submitted to parliament laws on partnership and corporations, secure transactions, and negotiable instruments. In the petroleum sector, the government continues to be involved in importation, storing, and wholesale trade of petroleum products. While reportedly refraining from employing price controls, the government influences retail petroleum prices through market interventions and the imposition of fees on private importers. ${ }^{7}$

\section{A tariff reform implemented in $\mathbf{2 0 0 6}$ sought to balance trade policy} liberalization and revenue considerations, but discretionary protectionist measures have subsequently crept in (Box 4). The 2006 reform intended to address instances of negative protection, but higher tariff bands on certain products were also introduced to safeguard fiscal revenue in light of political resistance to the introduction of excise taxes. ${ }^{8}$ Subsequently, in the first half of 2007, several ad hoc protectionist measures were introduced because of concerns about unfair competition from neighboring countries and the high cost of doing business in Afghanistan. One of these changes, the discretionary application of the 1 percent tariff rate, was removed in January 2008.

\footnotetext{
${ }^{7}$ Staff obtained conflicting information on the extent of government involvement in the petroleum sector. While there is no evidence of subsidies, the operations of the government-owned petroleum enterprise and their fiscal aspects remain nontransparent (MEFP $\$ 43$ ).

${ }^{8}$ After these changes, the simple average tariff increased from 4 percent to 5.7 percent.
} 
Box 4. Summary Import Tariff Schedule 1/

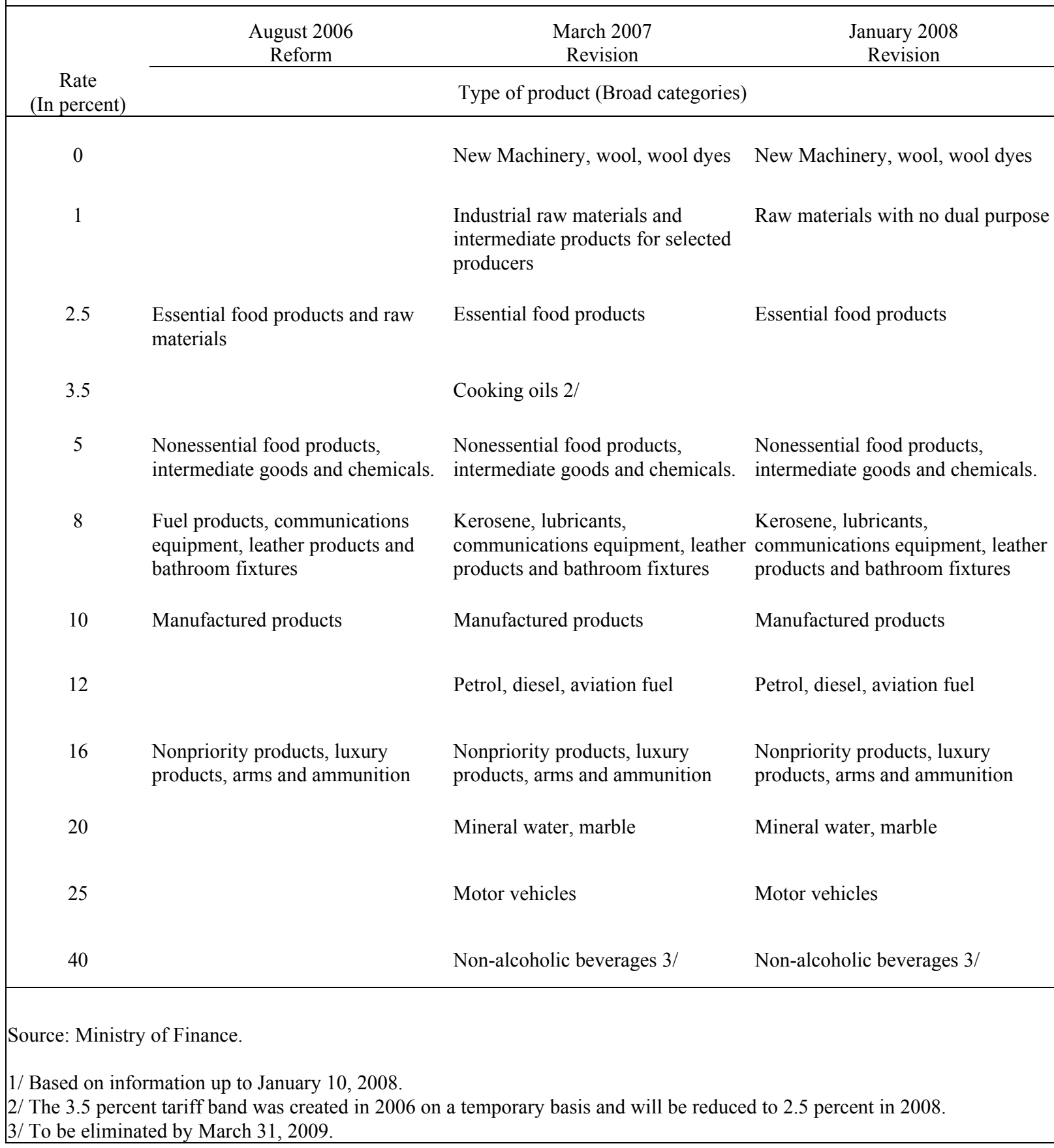


18. The authorities are implementing the interim ANDS (I-ANDS) and have made substantial progress in preparing the full ANDS (Afghanistan's PRSP). ${ }^{9}$ The ANDS preparation status report appropriately highlights the efforts made by the authorities to broaden the consultation on the ANDS and clearly articulates the steps toward its completion. The authorities intend to submit the full ANDS document to the Boards of the Fund and the World Bank by March 2008, as envisaged at the HIPC decision point in July 2007. This timetable may prove challenging, however, given the need for political decisions on key issues, including intersectoral prioritization. To avoid delays in completing the ANDS, the authorities have decided to limit the costing exercise to three sectors (health, education, and roads) whose expenditure envelopes will be aligned with the MTFF and the 2008/09 budget. The full costing of all sector strategies will be reflected in the first annual report on ANDS implementation.

\section{The authorities continue to develop controls against money laundering and} financing of terrorism (AML/CFT). Currently, all 16 banks in Afghanistan submit monthly reports on large cash and suspicious transactions to a specialized unit which was established in early $2006 .{ }^{10}$ The full-scale on-site examination of banks has revealed that most banks fell short of their obligations regarding the implementation of AML/CFT laws and regulations. These included staff's lack of access to internal regulations, insufficient training, and lack of communication of AML/CFT policies to branches. The authorities have directed banks to strengthen controls against money laundering and correct the observed deficiencies. Also, Hawala dealers (money changers) are now expected to report their operations using forms that have been developed for AML/CFT purposes.

\section{Medium-Term Outlook: Creating Conditions for Sustainable Growth}

\section{A. Overview}

20. The consultation discussions with the authorities focused on Afghanistan's medium-term policies and prospects in light of the expected decline in foreign assistance. The medium-term scenario assumes that the key obstacles to growth (including lack of electricity in Kabul and the precarious security environment) will be removed gradually. Main sources of growth would include: (i) licit agriculture benefiting from rural development programs and the implementation of the donor-supported strategy to eliminate poppy cultivation in favor of alternative crops; (ii) mining, supported by foreign direct investment; and (iii) concomitant broad-based growth in trade and services. Real GDP

\footnotetext{
${ }^{9}$ The authorities submitted to staff a status report on the progress made in implementing the I-ANDS and preparing the ANDS.

${ }^{10}$ The first AML/CFT evaluation of Afghanistan by the Asia Pacific Group on Money Laundering is scheduled for the third quarter of 2008.
} 
growth is projected to moderate from 9 percent in 2008/09 to 7 percent in 2012/13, reflecting a gradual decline in the investment-to-GDP ratio to about 30 percent in $2011 / 12 .{ }^{11}$ Donorfunded public investment is expected to remain critical for economic growth (Box 5), but its relative importance will diminish over time as private investment and foreign direct investment play increasing roles.

\section{Box 5. Macroeconomic Effects of Donor Assistance}

Nonsecurity grants for the external budget are expected to drop, as a percentage of GDP, from an estimated 30 percent this fiscal year to 9 percent in 2012/13, as immediate reconstruction needs recede and the government takes increasing responsibility for expenditures. At the same time, grants to the core budget would decline from 13.6 percent of GDP to 10.6 percent of GDP over the same period.

The significant level of security expenditures in the external budget reflects the cost of training, equipping, and supporting the increase in the national army and the police. This support is expected to decline as force levels stabilize and security improves.

Automatic sterilization due to the large import 'content of donor expenditures will help mitigate the potential "Dutch disease" effect of donor inflows on competitiveness. Also, it is expected that aid-financed investments in infrastructure and security will enhance productivity and competitiveness, thus offsetting potential pressure on the exchange rate from the sustained foreign aid to the core budget.

Medium-Term Implications of Donor Assistance

\begin{tabular}{|c|c|c|c|c|c|c|c|}
\hline & $2006 / 07$ & $2007 / 08$ & $2008 / 09$ & 2009/10 & $2010 / 11$ & $2011 / 12$ & $2012 / 13$ \\
\hline & \multicolumn{7}{|c|}{ (In percent of GDP) } \\
\hline Donor Support to Core Budget & 12.0 & 13.6 & 13.5 & 13.4 & 12.9 & 11.5 & 10.6 \\
\hline Grants (Operating budget) & 5.5 & 5.4 & 4.7 & 3.8 & 2.5 & 1.7 & 1.1 \\
\hline Grants (Development budget) & 4.7 & 6.1 & 7.2 & 8.3 & 8.8 & 8.5 & 8.2 \\
\hline Loans & 1.7 & 1.5 & 1.2 & 1.3 & 1.6 & 1.3 & 1.3 \\
\hline MDRI and HIPC assistance (flow) & 0.1 & 0.6 & 0.5 & 0.0 & 0.0 & 0.0 & 0.0 \\
\hline Overall fiscal balance excluding grants $1 /$ & -13.3 & -14.4 & -14.5 & -15.1 & -13.7 & -12.3 & -11.1 \\
\hline Overall fiscal balance including grants $1 /$ & -3.1 & -2.9 & -2.6 & -3.0 & -2.5 & -2.1 & -1.8 \\
\hline Donor Grants (External budget) & 55.4 & 54.5 & 51.7 & 38.1 & 30.8 & 23.6 & 18.1 \\
\hline Of which: security & 22.9 & 25.6 & 26.8 & 20.8 & 16.6 & 12.5 & 9.3 \\
\hline \multirow[t]{2}{*}{ External current account balance excluding grants } & -77.1 & -72.6 & -69.0 & -56.2 & -49.6 & -42.1 & -36.4 \\
\hline & \multicolumn{7}{|c|}{ (Annual percentage change; unless otherwise indicated) } \\
\hline Real GDP growth & 6.1 & 13.5 & 9.0 & 9.0 & 8.0 & 7.7 & 7.0 \\
\hline $\mathrm{CPI}$ (end period) & 4.8 & 12.0 & 9.0 & 6.0 & 6.0 & 5.0 & 5.0 \\
\hline Real exchange rate (appreciation + ) & -1.6 & $\ldots$ & $\ldots$ & $\ldots$ & $\ldots$ & $\ldots$ & $\ldots$ \\
\hline Exports & 1.2 & 7.8 & 20.3 & 17.4 & 16.4 & 16.7 & 16.6 \\
\hline Imports & 12.5 & 18.1 & 15.3 & -2.3 & 2.1 & -1.7 & -0.6 \\
\hline Gross international reserves (in millions U.S. dollars) & 2,064 & 2,335 & 2,525 & 2,450 & 2,305 & 2,170 & 2,025 \\
\hline
\end{tabular}

Sources: Data provided by the Afghan authorities; and Fund staff estimates and projections.

$1 /$ Includes MDRI and HIPC assistance.

\footnotetext{
${ }^{11}$ New information on the scope of planned donor-funded investment led to an upward revision of GDP growth in the medium-term outlook, compared with those presented in the HIPC decision document.
} 


\section{B. Fiscal Policy}

21. The authorities indicated that fiscal policy would seek to balance a "needsbased" approach to expenditure with a focus on fiscal sustainability. ${ }^{12}$ The operating budget deficit, excluding grants, is projected to decline from 4.0 percent of GDP in 2007/08 to 3.6 percent in $2008 / 09$. This improvement is dependent on containing expenditure and strengthening revenue, and is consistent with the government's stated objective of covering operating expenses from domestic revenue - a target that is expected to be achieved in $2012 / 13$. Core budget development expenditures are projected to average about $11 \frac{1}{2}$ percent of GDP over the same period, and will be mostly covered by donor grants and highly concessional lending.

\section{The government is committed to structural reforms aimed at creating fiscal} space for ANDS priorities, achieving the fiscal sustainability objective, and reducing risks to the fiscal outlook. The authorities intend to regularize relations between the budget and key public enterprises, reform the pension system, implement the pay and grade reform within the civil service, and strengthen public financial management (MEFP q26). The MTFF already reflects the cost of pay and rank reform in the army and the police, as well as in the civil service. The medium-term expenditure profile also includes some large expenditure items that are either one-off (such as election costs in 2009/10, which are estimated at 0.6 percent of GDP) or projected to fall (such as the energy subsidy, which is expected to decline as a result of structural reforms in the electricity sector).

\section{The authorities agreed on the need to strengthen domestic revenue mobilization} in order to generate resources for ANDS priorities and cope with fiscal uncertainties. Over the next year, the revenue efforts will focus primarily on: (i) intensifying administrative reforms; (ii) building capacity, especially in the provinces; (iii) consolidating the legislative base; and (iv) targeting high-income taxpayers. The authorities are also preparing legislation to transform the current Business Receipts Tax (BRT), a cascading turnover tax, into a broad-based consumption tax (MEFP $\mid 25$ ). They also plan to draft a new tax code to set a clear legislative base for the income tax and the BRT. These efforts are expected to yield a modest immediate increase in revenue, but would make a significant contribution toward fiscal sustainability in the coming years. Revenue from trade taxes is expected to increase in response to a higher level of taxable imports and the strengthening of customs and border controls.

24. Addressing security demands will depend on continued donor support over the medium term. The core budget outlook will need to accommodate the impact of recent

\footnotetext{
${ }^{12}$ For a detailed discussion of this topic refer to the accompanying selected issues paper on "Fiscal Sustainability in Afghanistan: A Framework to Cope with Security Pressures and External Aid."
} 
decisions to increase the size of both the army and the police (accompanied by the pay and rank reform in these sectors) on the government's wage bill. Donor support in this area will be critical for many years to come. The MOF, together with the World Bank and donors, has started a review of the budgetary implications of security expenditures.

\section{Monetary Policy}

\section{In the near term, monetary policy will continue to rely on foreign exchange} auctions and $\mathrm{CiC}$ targeting. Given the recent rebound in inflation, DAB has decided to adhere to its original $\mathrm{CiC}$ target for 2007/08 (which is below the program ceiling), in order to contain inflationary pressures. The ceiling for CiC growth in 2008/09 has been tentatively set at about 20 percent (Table 4), in line with projected nominal GDP growth. Developments in financial intermediation and improvements in the liquidity forecasting framework (MEFP $\{35$ ) may warrant shifting the focus toward more comprehensive monetary aggregates in the future.

\section{Deepening the market for CNs would further strengthen the effectiveness of} monetary policy and help reduce currency substitution. A decisive move by DAB to accept higher interest rates on CNs would encourage banks to increase interest differentials between Afghani and foreign-currency denominated deposits, and thus provide incentives for increasing the use of the Afghani. In addition, the development of a secondary market in CNs would allow DAB to increase reliance on these instruments. ${ }^{13}$

\section{The Financial Sector}

\section{The recent rapid growth of the banking sector underscores the need to} strengthen institutional capacity and the legal framework for the financial system. The lack of a core set of basic commercial laws, including laws on mortgages, secured transactions, and commercial arbitration, continue to prevent banks from providing credit to small and medium-sized businesses, thereby leaving it to the informal sector to fill in the gap. Moreover, financial institutions still lack the capacity to manage credit risk, and the enforcement capacity of DAB needs to be strengthened.

28. To address emerging risks in the banking sector, $D A B$ will continue its targeted supervisory actions and strengthen enforcement. The authorities have also agreed to place limits on the expansion of weak banks by restricting their credit growth to 5 percent per quarter and suspending the issuance of licenses for new branches. These measures will be in effect until the relevant banks' CAMEL ratings are reassessed to be less than 4 .

\footnotetext{
${ }^{13}$ The Fund is providing technical assistance to strengthen the legal framework for a secondary market in CNs.
} 
29. The authorities also plan to take measures aimed at improving the regulatory framework for the banking sector. In particular, DAB's Supreme Council will repeal the decisions instituting the requirement to invest 80 percent of bank deposits in the domestic economy and raising the minimum capital requirement for banks from US\$5 million to US\$20 million. DAB will issue circulars to inform banks about these decisions (MEFP 938 ). The minimum capital requirement, applicable immediately for new banks seeking licenses, will be set at US\$10 million, while incumbent banks will be given five years to comply.

\section{E. External Sector Issues}

30. Several factors indicate that there are no immediate risks to external stability and that the exchange rate is not misaligned. The robust growth of official exports and their increasing share of world exports (Figure 6) suggest that the real exchange rate is not a constraint on external competitiveness. There appears to be scope, however, for improving competitiveness by reducing institutional bottlenecks and lowering the cost of doing business (Box 6). While the lack of data precludes a formal analysis of the appropriateness of the exchange rate level, the stability of the CPI-based REER and (to a lesser extent) the ratio of nontradable to tradable prices suggests that the real exchange rate is broadly in line with fundamentals (Figure 7). The current account balance (before grants) is expected to strengthen gradually over the medium term in step with an improving trade balance and full delivery of debt relief under the HIPC Initiative.

\section{Safeguarding medium-term external sustainability requires further} improvements in the competitiveness of the economy and a renewed commitment to a liberal trade regime. The authorities are of the view that the projected decline in donor inflows will be partly offset by sizeable foreign direct investments. Other countries' experience suggest, however, that while large-scale foreign investment has a positive effect on the economy, its impact on the balance of payments and fiscal revenue tends to be less pronounced. There will be a need, therefore, for a broad-based increase in exports. This would require maintaining a liberal trade regime and addressing the major impediments to export growth, notably the shortage of electricity and other infrastructure bottlenecks. 


\section{Box 6. External Competitiveness}

Afghanistan's official exports have increased from 3.7 percent of GDP in 2002/03 to 7.8 percent in 2006/07, growing at an average annual rate of 37 percent. As a share of world exports, the country's official exports rose from 0.02 to 0.05 percent during the same period. Growth in carpet exports has been particularly impressive, with an average annual rate of almost 280 percent in value terms and 120 percent in volume terms between 2002/03 and 2006/07.

Afghanistan's robust export performance in recent years appears to be related to increased capacity utilization. After the appreciation of the REER in May 2004 (due largely to pressure on the housing market from the influx of donors), the REER has remained broadly stable, suggesting that "Dutch Disease" effects from donor assistance and opium exports have been contained.

Structural bottlenecks suggest that there is significant scope for improving competitiveness. ${ }^{1}$ According to the World Bank, Afghanistan currently ranks 159 out of 178 economies in terms of overall ease of doing business. Difficulties faced by Afghan companies include the high cost of credit, high input costs, and the cost of trading across borders (exporting a container costs more than twice the average in the rest of the region and requires more than twice as many days). Input costs include the high cost of electricity in Kabul and unreliable supply with the result that most businesses rely on their own electricity at a very high cost.

The high cost of doing business is compounded by a difficult institutional environment. Based on the governance indicators from the World Bank for 2006, Afghanistan's institutional environment has weakened in the areas of political stability, government effectiveness, and the rule of law.

1/ A detailed analysis of the institutional and structural bottlenecks in Afghanistan was conducted in the selected issues paper on "Indicators of Afghanistan's external competitiveness" that was prepared in the context of the 2005 Article IV consultation. 
Figure 6. Islamic Republic of Afghanistan: Share of Exports of Goods and Services 2002/03-2006/07

(In units as indicated)

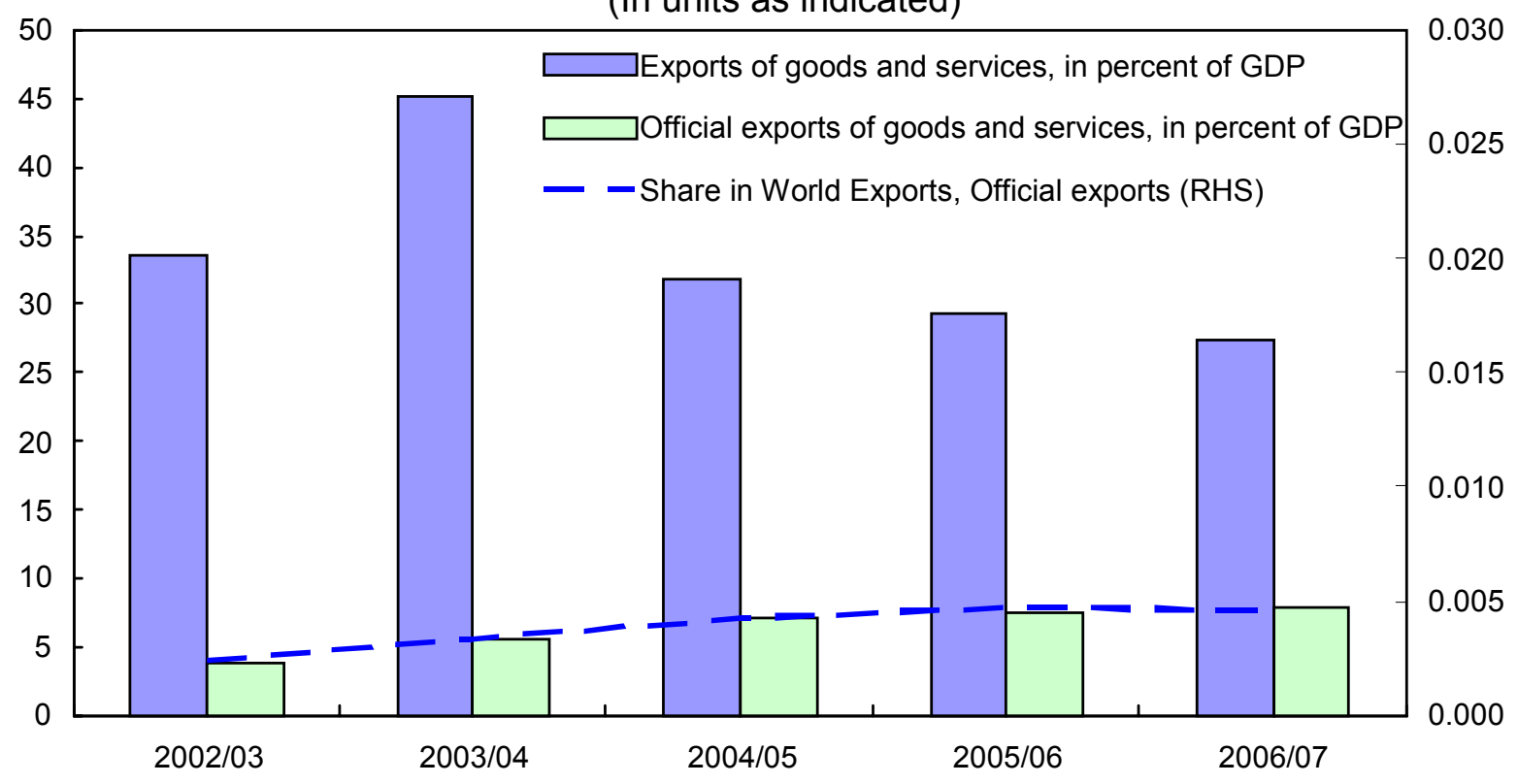

Sources: Data provided by the Afghan authorities; World Economic Outlook; and Fund staff estimates.

Figure 7. Islamic Republic of Afghanistan: Exchange Rates and Ratio of Nontradable to Tradable Prices, Jan 2003-Oct 2007 $(2003 / 04=100) 1 /$

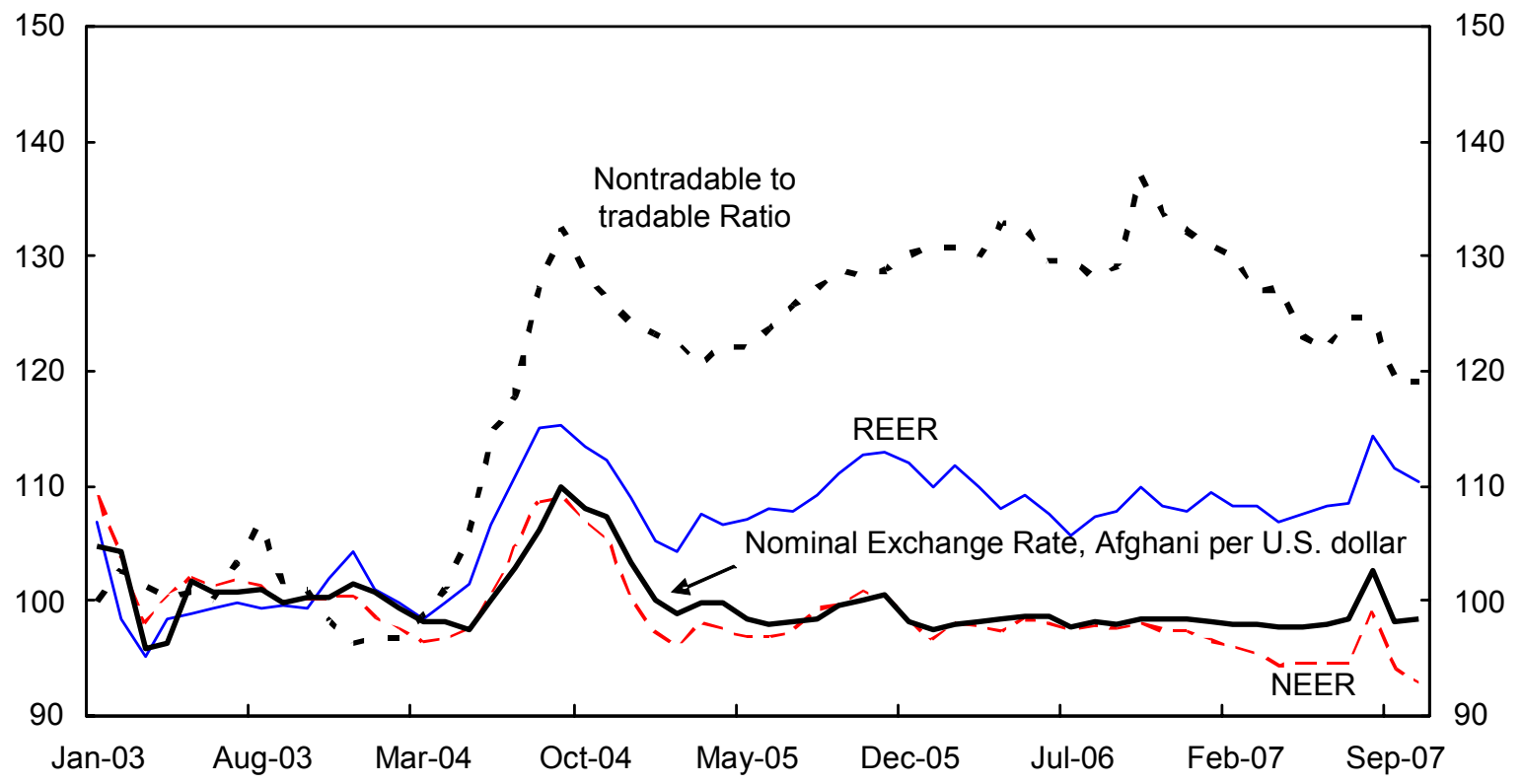

Sources: Da Afghanistan Bank (DAB); and Fund staff estimates and projections. 


\section{The PRGF-Supported Program}

32. All the end-September $\mathbf{2 0 0 7}$ quantitative performance criteria under the PRGFsupported program were observed (MEFP Table 1). Despite a weak revenue performance in the first quarter of $2007 / 08$, the authorities were able to meet the mid-year domestic revenue target with a comfortable margin. They remain confident that the end-year target will also be observed, but stand ready to take appropriate actions, in consultation with Fund staff, should any revenue shortfalls occur in the second half of 2007/08.

\section{The implementation of the structural conditionality for the third program} review was mixed, leading to revisions in the structural agenda (MEFP Table 2). The structural performance criterion on submitting to parliament the core budget's audited financial statement for $2006 / 07$ by September 21, 2007, was missed by one day, with the submission taking place on September 22, 2007. The structural benchmark calling for the adoption by the Cabinet of a comprehensive restructuring plan for the public entities and government agencies engaged in commercial activities but not covered by the SOEs law was also missed. The timeline for the preparation of this plan has been revised with a view to obtaining Cabinet approval by March 31, 2008. DAB has also incurred delays regarding two structural benchmarks for end-November 2007, one calling for the issuance of regulations on credit-granting standards and the credit-monitoring process and, the other setting limits on sector loan concentration. It is expected that both regulations will be issued in early February 2008. The structural benchmark on submitting for Cabinet approval a restructuring plan for Bank Pashtany has been only partially implemented as the plan was not based on the bank's audited financial statement. The other three structural benchmarks were met without qualifications.

\section{Two prior actions that were proposed in the context of the safeguards} assessment have been incorporated in the program: (i) completion of a special audit of DAB's reserve assets; and (ii) appointment of a reputable audit firm to perform an audit of DAB's financial statements for financial year 2007/08. A third prior action consisted of the elimination of the discretionary application of a 1 percent tariff rate on imports of selected industrial inputs. All three actions have been implemented. The authorities also agreed to implement a full set of updated safeguards recommendations (MEFP $\$ 36$ ).

35. The quantitative program for the remainder of $2007 / 08$ has been revised to take into account the midyear budget review, in line with the understandings reached at the time of the second PRGF review (MEFP q22). The revisions affecting fiscal targets (indicative targets for December 2007 and performance criteria for March 2008) reflect mainly the inclusion in the budget of additional security expenditures previously left outside its scope, pending confirmation of donor financing. Since the authorities observed the September revenue target, the midyear review also allows for a limited amount (equivalent of 0.3 percent of GDP) in additional nonsecurity expenditure, consistent with earlier understandings. The targets for net international reserves have been revised upward to 
realign the monetary program for the remainder of 2007/08 with developments through September 2007, notably, significantly larger-than-expected inflows of off-budget foreign assistance. The PRGF arrangement is fully financed through end-2008/09.

36. The authorities recognized the need to refocus the program and address risks emerging in several areas. In addition to revenue efforts, public expenditure management and central bank reforms, the program now also aims to deal with: (i) issues pertaining to the government's role in the economy, including its involvement in the domestic petroleum market and the trade policy stance; and (ii) the management of potential fiscal drains mainly stemming from the government's relations with public enterprises (e.g., DABM-the electricity provider, and Ariana - the national airline). ${ }^{14}$

\section{Staff Appraisal}

37. Afghanistan has made substantial progress toward macroeconomic stability, but structural reforms need to be accelerated. Fiscal revenues have increased steadily and monetary policy has been strengthened, but progress in other structural areas, including much needed measures to create the infrastructure and legislation necessary for private sector development, has been slow. A vigorous implementation of the reform agenda under the PRGF-supported program is crucial for maintaining macroeconomic stability and improving Afghanistan's growth and poverty alleviation prospects.

38. Looking ahead, revenue efforts will play a central role in moving Afghanistan gradually toward fiscal sustainability. Fiscal policy will continue to focus on tax reforms and other revenue enhancing measures, which will require support at the top levels of government. Key steps will include parliamentary approval for moving the BRT toward a much-needed broad-based consumption tax and restarting the preparations for introducing an excise tax.

39. The uncertainty affecting the fiscal outlook also warrants a prudent expenditure policy. Discipline will be required to observe expenditure ceilings and prioritize the use of scarce resources, and to make the adjustments necessary for achieving fiscal sustainability. Given the high dependence on external aid, it would be prudent for the authorities to maintain a buffer of deposits at DAB and prepare for developing a domestic debt market over the medium term.

40. The recent strengthening of the MTFF is a positive development that has contributed to improving the strategic aspects of fiscal policy, but further efforts are necessary in this area. The high dependence on external support highlights the need to deal

\footnotetext{
${ }^{14}$ A list of structural benchmarks is included in Table 2 of the MEFP and their detailed description is in the Technical Memorandum of Understanding (TMU).
} 
with fiscal sustainability and aid volatility within a robust and systematic planning framework. The availability of data on donor activity outside the core budget would significantly strengthen fiscal analysis underlying the MTFF.

41. Monetary policy has been instrumental in reducing inflation and safeguarding external stability but it needs to be strengthened. The rebound of inflation in 2007/08, albeit largely due to exogenous causes, calls for increased reliance on CNs and the development of a secondary market for these instruments. This would also help reduce the degree of dollarization.

42. The financial sector needs to be thoroughly supervised and properly regulated. Staff welcome the actions undertaken by DAB to strengthen banking supervision, limit the expansion of weak banks, and refine the regulatory provisions pertaining to banks' domestic investment and the minimum capital requirements. Also, DAB's recent self-assessment against the Basle Core Principles provides a useful tool for addressing weaknesses in banking supervision. Looking ahead, it is important that DAB continues its targeted supervisory actions and strengthen enforcement. Also, there is a need to bring the restructuring of the state-owned banks to a successful conclusion based on sound market principles, and to adopt promptly several pieces of legislation that are critical for private sector growth and financial sector stability, including the laws on mortgages, secured transactions, and commercial arbitration.

43. The government should resist pressures for expanding its role in the economy and focus on fostering competition and improving economic governance. In this context, staff welcome the authorities' commitment to reducing gradually the FLGE's involvement in the petroleum sector, limiting its role to providing services to the private sector, and making its operations fully transparent. The government's relations with SOEs need to be clarified with a view to improving transparency and stemming potential fiscal drains.

44. The current exchange rate regime is serving Afghanistan well and the exchange rate level appears broadly in line with fundamentals. Nevertheless, safeguarding mediumterm external stability requires further improvements in the competitiveness of the economy and a renewed commitment to a liberal trade regime.

\section{Every effort should be made to maintain a trade regime that minimizes} distortions and does not discriminate across traders. In this regard, the agreed upon unwinding of tariff increases on soft drinks and the elimination of the discretionary 1 percent tariff rate on raw materials provide an important signal of renewed commitment by the authorities to an open trade regime. In the period ahead, it would be important to avoid introducing further ad hoc changes to the tariff schedule and other protectionist measures.

46. The ANDS should aim at improving the alignment of public spending with the government's priorities. It should integrate sectoral strategies with the government's 
growth and poverty reduction objectives, and ensure maximum effectiveness of public investment while taking into account the absorptive capacity of the economy.

47. The authorities need to increase their efforts to improve Afghanistan's statistical database. In this process, priority should be given to strengthening the Central Statistics Office and improving coordination among data providers and the compilation of national income data. While data provision is adequate for overall surveillance purposes, donor assistance is needed to overcome shortcomings in some areas, such as the balance of payments and the national accounts.

48. Staff support the waiver of nonobservance for the structural performance criterion on the submission to parliament of the core budget's audited financial statement for 2006/07 by September 21, 2007 and, based on the performance to date, recommends the completion of the third review under the PRGF supported arrangement. The nonobservance of the structural performance criterion was due to a minor delay, and the authorities complied with the Public Finance and Expenditure Management Law. Moreover, Afghanistan is expected to encounter no difficulties in meeting its obligations to the Fund.

49. It is proposed that the next Article IV consultation with Afghanistan take place in accordance with the decision on consultation cycles of July 15, 2002. 
Figure 8. Islamic Republic of Afghanistan: Monetary Developments

a) Currency in Circulation, 2005/06-2007/08

(Year-to-date change; in percent)

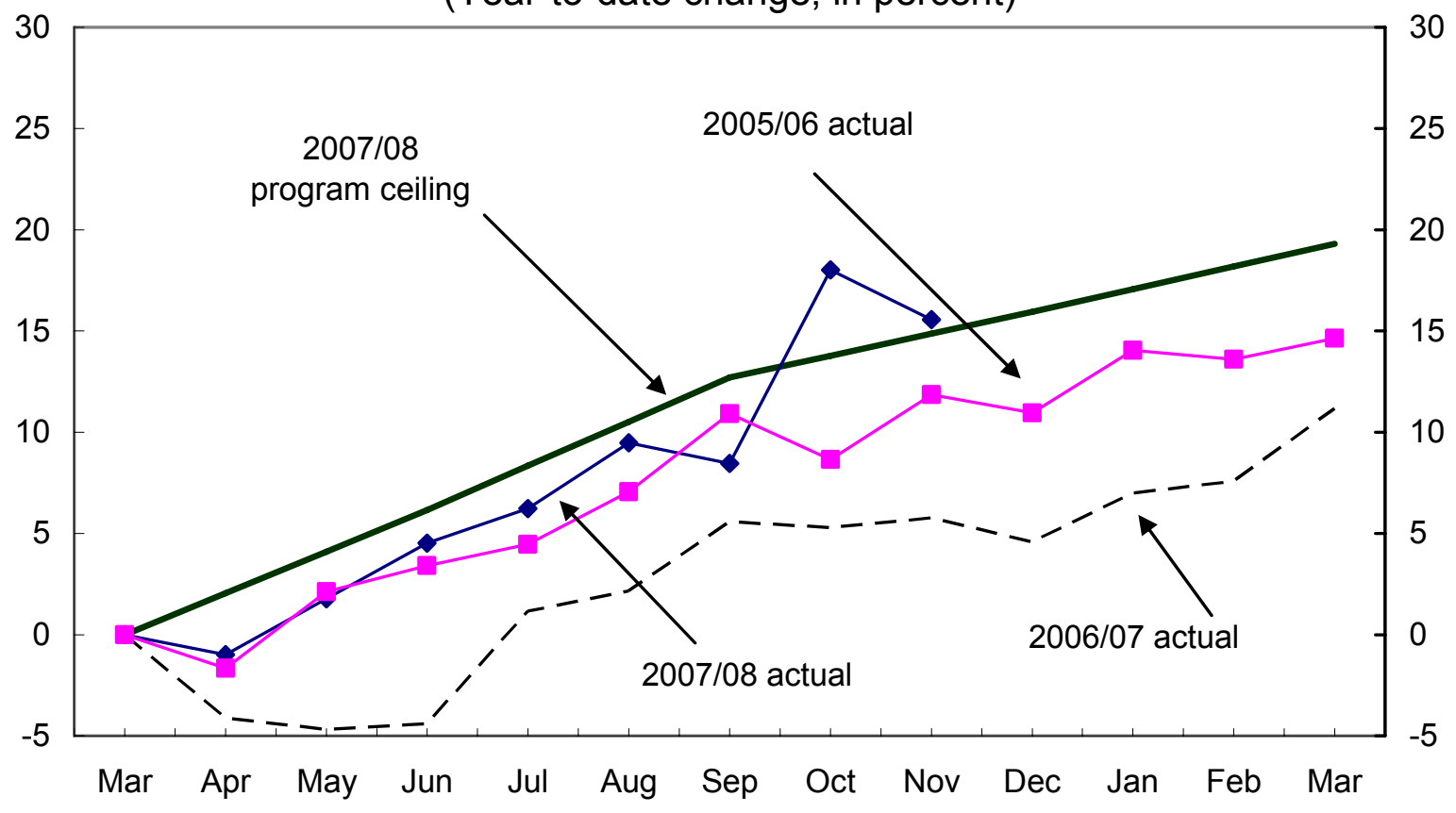

b) Capital Note Auctions, September 2004-October 2007 1/

(Interest rate; in percent)

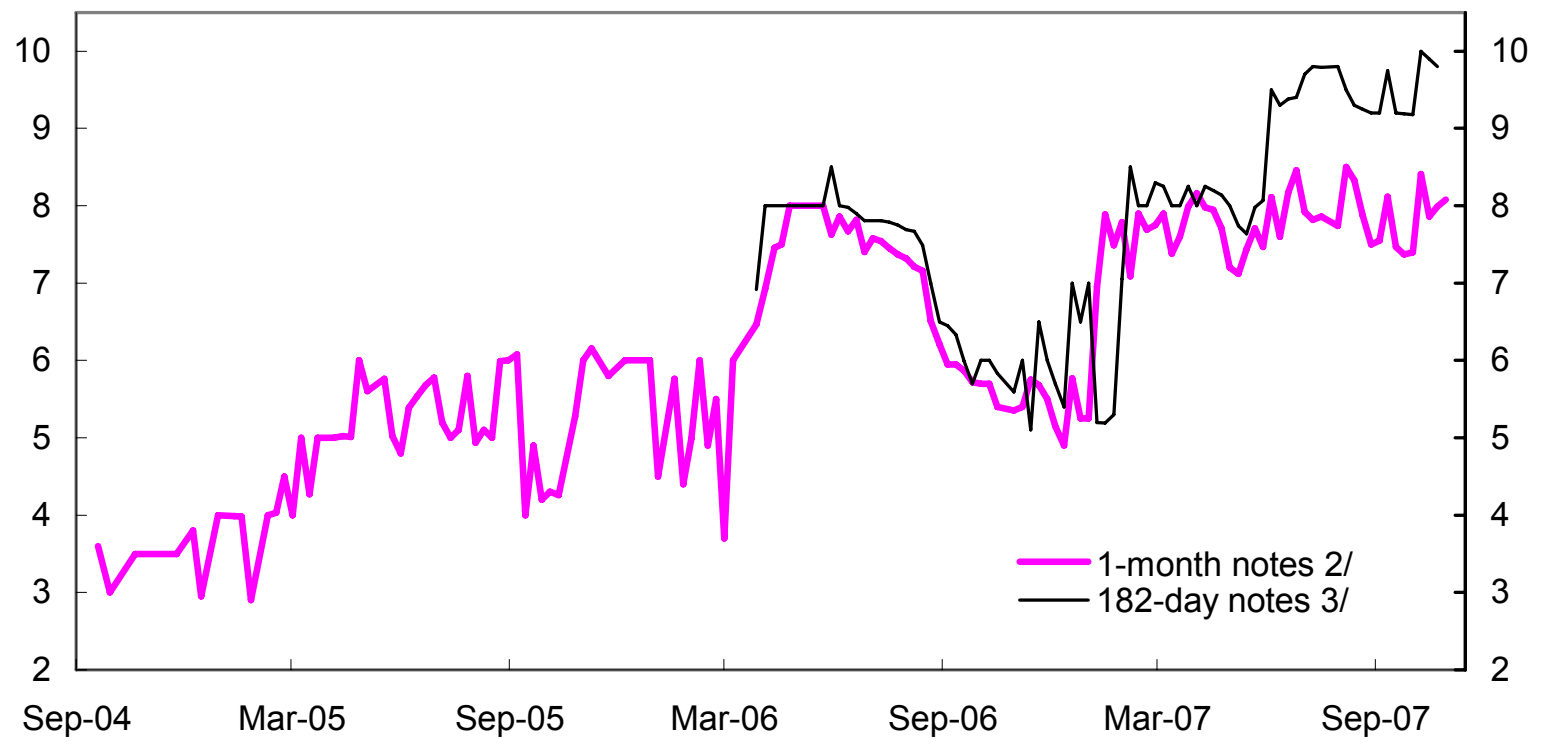

Sources: Da Afghanistan Bank; and Fund staff estimates and projections.

1/ Last observation: October 30, 2007.

2/ 30-day notes from September 2004-March 3, 2006. 28-day notes from March 28, 2006.

3/ 56-day notes until February 27, 2007. 
Figure 9. Islamic Republic of Afghanistan: Foreign Exchange Reserves and Real Exchange Rate

a) DAB's Foreign Exchange Reserves,

March 2005-October 2007 1/

(In millions of U.S. dollars)

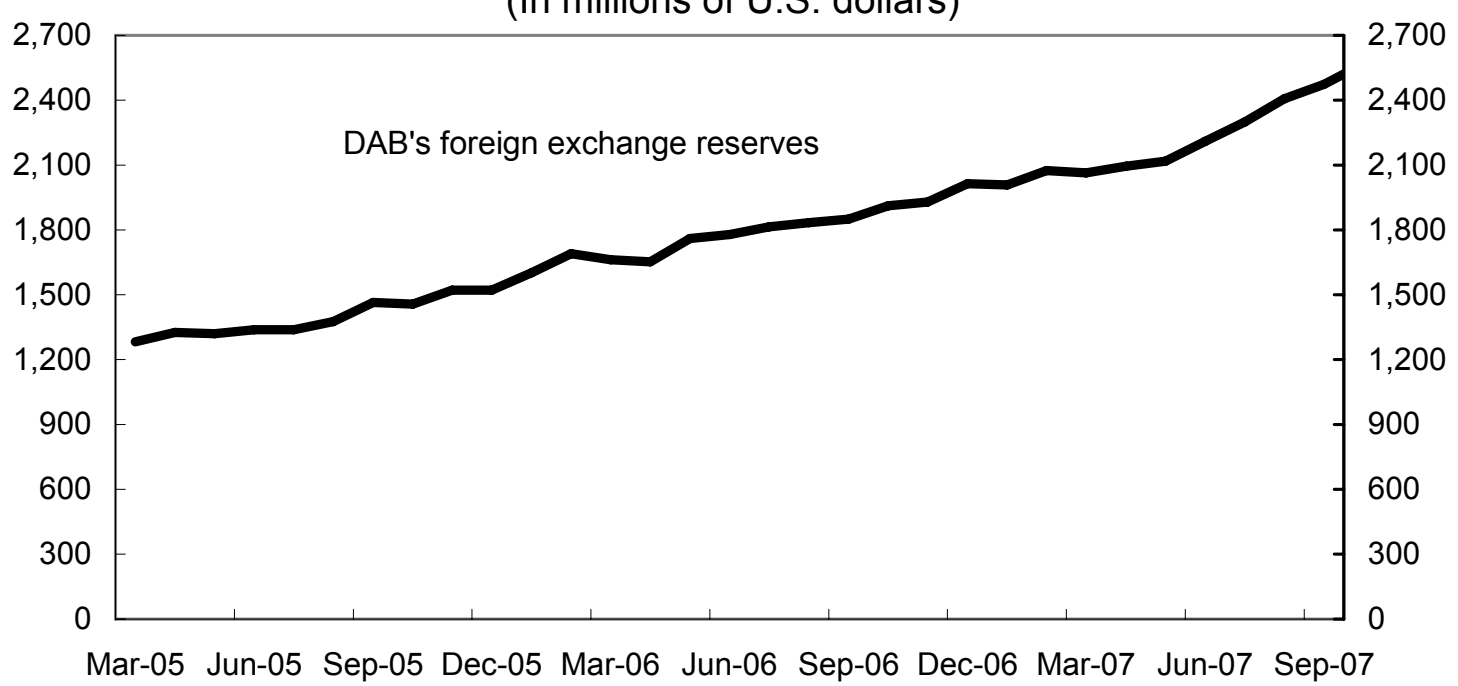

b) Price and Exchange Rate Indices, March 2004-Nov 2007 2/ $(2003 / 2004=100)$

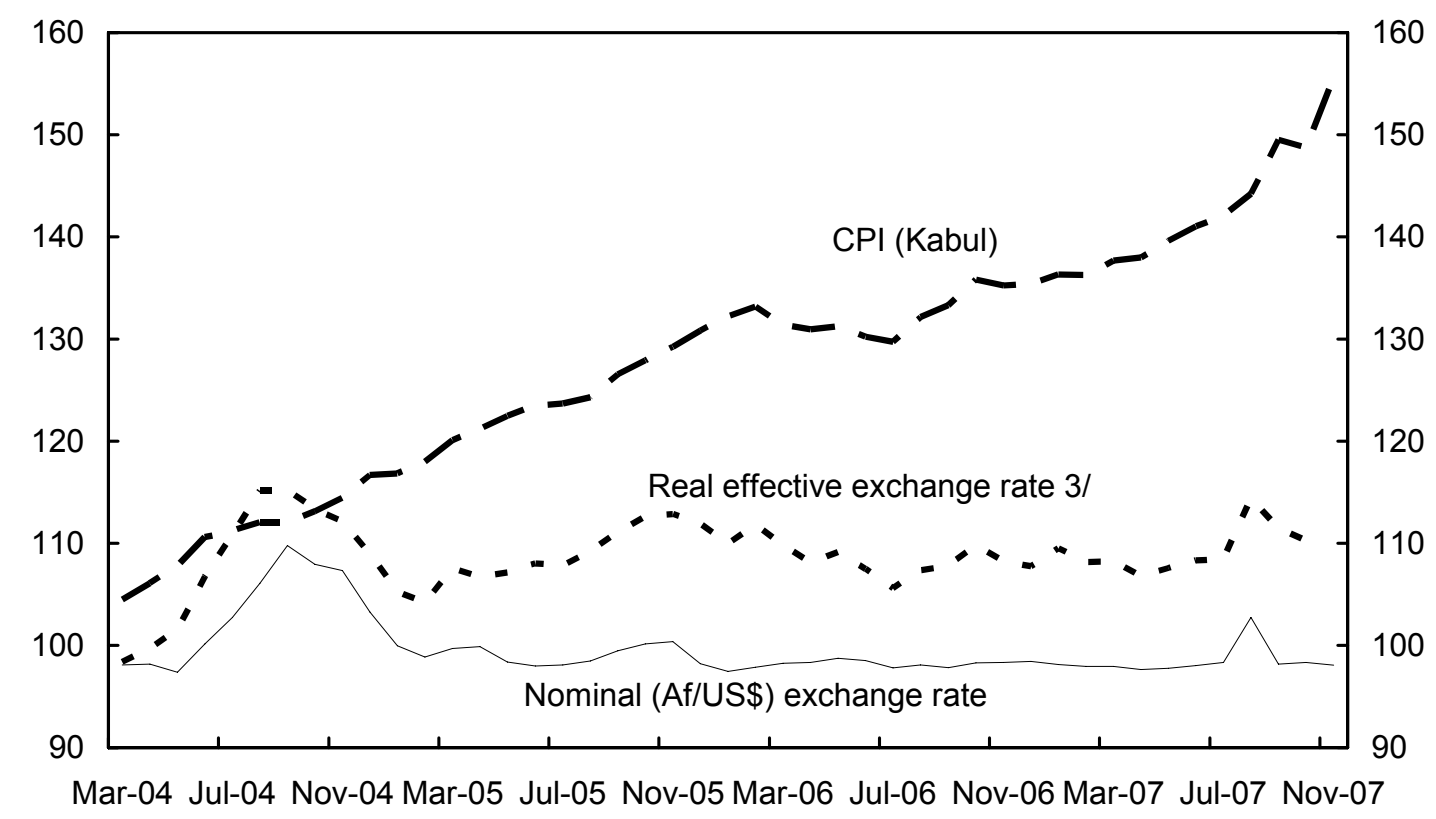

Sources: Central Statistics Office of Afghanistan; Da Afghanistan Bank; and Fund staff estimates.

1/ Last observation: October 2007.

2/ An increase in the exchange rate indices corresponds to an appreciation.

3/ CPI based; last observation: October 2007. 
Table 1. Islamic Republic of Afghanistan: Selected Economic Indicators, 2005/06-2012/13

(Quota: SDR 161.9 million)

(Population: 25.7 million; 2005/06)

(Per capita GDP: US\$250; 2005/06)

(Poverty rate: n.a.)

(Main export: carpets, US\$186 million; 2006/07)

\begin{tabular}{|c|c|c|c|c|c|c|c|c|}
\hline & \multirow{2}{*}{$\frac{\text { Est. }}{2005 / 06}$} & \multirow{2}{*}{$\frac{\text { Est. }}{2006 / 07}$} & \multicolumn{6}{|c|}{ Projections } \\
\hline & & & $2007 / 08$ & $2008 / 09$ & $2009 / 10$ & $2010 / 11$ & $2011 / 12$ & $2012 / 13$ \\
\hline & & (Annua & I percenta & ge change; & unless oth & erwise ind & cated) & \\
\hline \multicolumn{9}{|l|}{ Output and prices $1 /$} \\
\hline Real GDP & 16.4 & 6.1 & 13.5 & 9.0 & 9.0 & 8.0 & 7.7 & 7.0 \\
\hline Nominal GDP (in millions of Afghanis) & 321,939 & 351,771 & 436,646 & 523,466 & 609,782 & 696,182 & 788,325 & 883,729 \\
\hline Nominal GDP (in millions of U.S. dollars) & 6,483 & 7,048 & 8,719 & 10,453 & 12,176 & 13,901 & 15,741 & 17,646 \\
\hline Consumer prices (period average) $2 /$ & 12.3 & 5.1 & 9.8 & 10.2 & 7.2 & 6.0 & 5.4 & 5.0 \\
\hline \multirow[t]{2}{*}{ Consumer prices (end of period) 21} & 9.4 & 4.8 & 12.0 & 9.0 & 6.0 & 6.0 & 5.0 & 5.0 \\
\hline & \multicolumn{8}{|c|}{ (In percent of GDP) } \\
\hline \multicolumn{9}{|l|}{ Investment and saving } \\
\hline Gross domestic investment & 44.6 & 46.0 & 40.3 & 38.6 & 33.6 & 31.8 & 29.8 & 28.8 \\
\hline Of which: nongovernment & 9.6 & 8.9 & 8.9 & 9.0 & 9.5 & 10.6 & 11.7 & 13.0 \\
\hline Gross domestic savings & 41.8 & 39.7 & 38.9 & 38.1 & 32.4 & 28.8 & 25.8 & 23.9 \\
\hline Of which: nongovernment & 45.4 & 43.9 & 43.0 & 41.7 & 35.8 & 30.7 & 26.7 & 23.8 \\
\hline \multicolumn{9}{|l|}{ Public finances } \\
\hline Operating revenue (including grants) $3 /$ & 11.6 & 13.6 & 13.6 & 13.2 & 12.9 & 12.2 & 12.0 & 12.0 \\
\hline Operating expenditure $3 /$ & 10.0 & 12.4 & 12.2 & 12.1 & 12.6 & 11.7 & 11.2 & 10.8 \\
\hline Operating budget balance (excluding grants) $3 /$ & -3.6 & -4.2 & -4.0 & -3.6 & -3.5 & -1.9 & -0.9 & 0.1 \\
\hline Operating budget balance (including grants) $3 /$ & 1.6 & 1.3 & 1.4 & 1.1 & 0.4 & 0.5 & 0.8 & 1.2 \\
\hline Primary operating balance (including grants) $3 /$ & 1.6 & 1.3 & 1.4 & 1.2 & 0.4 & 0.6 & 0.9 & 1.3 \\
\hline Core budget balance (including grants) & 1.0 & -3.1 & -2.9 & -2.6 & -3.0 & -2.5 & -2.1 & -1.8 \\
\hline \multirow[t]{2}{*}{ Total government debt $4 /$} & 184.2 & 170.9 & 21.6 & 20.0 & 10.0 & 10.3 & 10.4 & 10.5 \\
\hline & \multicolumn{8}{|c|}{ (Annual percentage change; unless otherwise indicated) } \\
\hline \multicolumn{9}{|l|}{ Monetary sector } \\
\hline Credit to the private sector & $\ldots$ & $\ldots$ & $\ldots$ & $\ldots$ & $\ldots$ & $\ldots$ & $\ldots$ & $\ldots$ \\
\hline Broad money & & & & & $\ldots$ & $\ldots$ & $\ldots$ & $\ldots$ \\
\hline Currency in circulation (year-to-date change) & 14.6 & 10.0 & 19.3 & 19.9 & $\ldots$ & $\ldots$ & $\ldots$ & $\ldots$ \\
\hline Velocity of broad money & & & & $\ldots$ & $\ldots$ & $\ldots$ & $\ldots$ & $\ldots$ \\
\hline \multirow[t]{2}{*}{ One-month capital note interest rate (end-period, in percent) $5 /$} & 6.5 & 7.6 & 10.5 & $\ldots$ & $\ldots$ & $\ldots$ & $\ldots$ & $\ldots$ \\
\hline & \multirow{2}{*}{\multicolumn{8}{|c|}{ (In percent of GDP; unless otherwise indicated) }} \\
\hline External sector $6 /$ & & & & & & & & \\
\hline Exports of goods (in U.S. dollars, percentage change) $7 /$ & 22.2 & 1.2 & 7.8 & 20.3 & 17.4 & 16.4 & 16.7 & 16.6 \\
\hline Imports of goods (in U.S. dollars, percentage change) 8 / & 25.5 & 12.5 & 18.1 & 15.3 & -2.3 & 2.1 & -1.7 & -0.6 \\
\hline Imports excluding security related expenditure (in U.S. dollars, percentage change) & 10.8 & 16.8 & 12.9 & 12.1 & 0.3 & 5.6 & 1.9 & 3.1 \\
\hline Merchandise trade balance & -66.9 & -70.1 & -67.6 & -64.7 & -53.1 & -46.6 & -39.3 & -33.7 \\
\hline Current account balance, excluding official transfers & -75.3 & -77.1 & -72.6 & -69.0 & -56.2 & -49.6 & -42.1 & -36.4 \\
\hline Current account balance, including official transfers & -2.8 & -6.3 & -1.4 & -0.5 & -1.2 & -3.0 & -4.0 & -4.9 \\
\hline Foreign direct investment & 4.2 & 3.4 & 3.3 & 3.3 & 3.4 & 3.9 & 4.0 & 4.1 \\
\hline Total external debt $4 /$ & 184.2 & 170.9 & 21.6 & 20.0 & 10.0 & 10.3 & 10.4 & 10.6 \\
\hline Gross reserves (in millions of U.S. dollars) & 1,662 & 2,064 & 2,335 & 2,525 & 2,450 & 2,305 & 2,170 & 2,025 \\
\hline In months of next year imports of goods and services $9 /$ & 7.7 & 9.3 & 9.4 & 9.2 & 8.0 & 6.9 & 5.9 & 5.1 \\
\hline Relative to external debt service due & 44.3 & 43.3 & 37.5 & 39.6 & 157.9 & 133.0 & 114.1 & 63.6 \\
\hline \multicolumn{9}{|l|}{ Memorandum items: } \\
\hline External budget grants (in billions of Afghanis) & 56.1 & 55.4 & 54.5 & 51.7 & 38.1 & 30.8 & 23.6 & 18.1 \\
\hline Unemployment rate (in percent) & & & $\ldots$ & $\ldots$ & $\ldots$ & $\ldots$ & $\ldots$ & ... \\
\hline Afghanis per U.S. dollar (period average) & 49.7 & 49.9 & $\ldots$ & $\ldots$ & $\ldots$ & $\ldots$ & $\ldots$ & ... \\
\hline Real effective exchange rate (annual average, percentage change) 10/ & 1.2 & -1.6 & $\ldots$ & $\ldots$ & $\ldots$ & $\ldots$ & $\ldots$ & $\ldots$ \\
\hline
\end{tabular}

Sources: Data provided by the Afghan authorities; and Fund staff estimates and projections.

1/ National accounts numbers were revised to reflect the authorities' data, excluding the drug economy.

2/ For Kabul.

3/ Does not include core budget development spending and externally-financed development expenditures, which amounted to 9.2 percent of GDP and 55.4 percent of GDP, respectively, in 2006/07

4/ After HIPC and MDRI relief as well as debt relief beyond HIPC relief from Paris Club creditors. Debt also includes obligations to the IMF. The debt stock includes the capitalization of interest to Paris Club creditors until completion point under the Enhanced HIPC Initiative. The large increase in the debt in 2005/06 reflects principally

the recognition of Russia's claims (that were subsequently restructured), and the reconciliation of all March 2006 debt stocks for the HIPC Initiative.

$5 /$ The $2007 / 08$ number is for January 1,2008

6/ Figures have been revised as a result of more reliable data on public grants.

7/ Includes official recorded exports plus staff estimates of smuggling; excludes reexports.

8/ Excludes reexports.

9/ In months of imports of goods and services, excluding imports for reexports and duty free imports by donors.

$10 /$ An increase in the exchange rate indices corresponds to an appreciation. 
Table 2a. Islamic Republic of Afghanistan: Core Budget, 2005/06-2012/13 1/ (In millions of Afghanis)

\begin{tabular}{|c|c|c|c|c|c|c|c|c|c|c|c|}
\hline & $\begin{array}{c}\text { Est. } \\
2005 / 06\end{array}$ & $\begin{array}{c}\text { Est. } \\
2006 / 07\end{array}$ & $\begin{array}{c}\text { YTD } \\
2007 / 08\end{array}$ & $\begin{array}{c}\text { MYR } \\
2007 / 08\end{array}$ & $\begin{array}{l}\text { Program } \\
2007 / 08\end{array}$ & $\begin{array}{c}\text { Proj. } \\
\text { 2007/08 }\end{array}$ & $\begin{array}{l}\text { Proj. } \\
\text { 2008/09 }\end{array}$ & $\begin{array}{l}\text { Proj. } \\
\text { 2009/10 }\end{array}$ & $\begin{array}{l}\text { Proj. } \\
\text { 2010/11 }\end{array}$ & $\begin{array}{c}\text { Proj. } \\
2011 / 12\end{array}$ & $\begin{array}{l}\text { Proj. } \\
\text { 2012/13 }\end{array}$ \\
\hline Domestic revenue & 20,660 & 28,789 & 15,501 & 35,773 & 35,721 & 35,721 & 44,539 & 55,606 & 68,044 & 81,142 & 96,273 \\
\hline Tax revenues & 14,035 & 21,893 & 11,602 & 30,735 & 27,629 & 27,629 & 34,753 & 44,077 & 54,680 & 65,773 & 78,740 \\
\hline Taxes on income, profits, and capital gains & 2,621 & 3,850 & 2,231 & 11,363 & 4,933 & 4,933 & 6,402 & 8,082 & 10,024 & 12,294 & 14,933 \\
\hline Taxes on international trade and transactions & 9,446 & 11,980 & 6,350 & 16,106 & 15,074 & 15,074 & 18,575 & 22,773 & 27,415 & 32,496 & 38,499 \\
\hline Domestic taxes on goods and services & 1,771 & 4,946 & 2,693 & & 6,338 & 6,338 & 8,225 & 11,405 & 15,135 & 18,562 & 22,536 \\
\hline Other taxes & 197 & 1,117 & 328 & 3,266 & 1,284 & 1,284 & 1,550 & 1,816 & 2,107 & 2,421 & 2,772 \\
\hline Nontax revenues & 6,624 & 6,896 & 3,899 & 5,038 & 8,092 & 8,092 & 9,786 & 11,529 & 13,363 & 15,369 & 17,533 \\
\hline Donor assistance grants (to operating budget) $2 /$ & 16,732 & 19,214 & 5,903 & 24,050 & 23,316 & 23,617 & 24,593 & 23,232 & 17,060 & 13,594 & 9,716 \\
\hline ARTF (recurrent window) & 12,572 & 14,947 & 3,218 & 13,500 & 14,022 & 14,523 & 13,522 & 12,019 & 10,517 & 9,014 & 6,510 \\
\hline LOTFA & 4,068 & 3,722 & 2,136 & 7,350 & 6,193 & 7,493 & 9,247 & 9,347 & 6,543 & 4,580 & 3,206 \\
\hline Other grants & 92 & 544 & 549 & 3,200 & 3,101 & 1,601 & 1,824 & 1,866 & $\ldots$ & $\ldots$ & $\ldots$ \\
\hline Donor assistance grants (core development budget) & 19,251 & 16,625 & 16,152 & 60,068 & 25,928 & 26,793 & 37,523 & 50,784 & 61,212 & 66,642 & 72,381 \\
\hline Total core budget expenditure & 53,437 & 75,702 & 34,719 & 141,800 & 97,691 & 98,812 & 120,293 & 147,755 & 163,391 & 178,243 & 194,565 \\
\hline Operating expenditure & 32,348 & 43,448 & 19,935 & 54,800 & 53,595 & 53,329 & 63,439 & 76,688 & 81,489 & 88,187 & 95,413 \\
\hline Wages and salaries & 20,430 & 26,454 & 14,093 & 33,874 & 32,428 & 33,728 & 39,641 & 46,444 & 51,584 & 56,385 & 59,785 \\
\hline Purchase of goods and services & 6,679 & 10,200 & 4,011 & 11,997 & 11,808 & 10,308 & 13,341 & 19,223 & 18,443 & 21,490 & 24,316 \\
\hline Transfers, subsidies, and other & 495 & 2,176 & 67 & 5,066 & 4,765 & 4,765 & 4,787 & 4,858 & 4,680 & 2,931 & 3,286 \\
\hline Pensions & 1,540 & 2,461 & 1,254 & 2,465 & 2,773 & 2,773 & 3,557 & 3,813 & 4,042 & 4,261 & 4,474 \\
\hline Capital expenditure & 3,054 & 1,987 & 335 & 996 & 1,437 & 1,437 & 1,723 & 2,007 & 2,291 & 2,594 & 2,908 \\
\hline Interest 3 / & 150 & 169 & 176 & 403 & 384 & 318 & 390 & 344 & 450 & 526 & 645 \\
\hline Core budget development spending 4 / & 21,089 & 32,254 & 14,784 & 87,000 & 44,096 & 45,483 & 56,853 & 71,067 & 81,903 & 90,057 & 99,152 \\
\hline \multicolumn{12}{|l|}{ Interim Afghanistan National Development Strategy programs } \\
\hline Security & 1,122 & 1,408 & 368 & 2,980 & 1,891 & 1,891 & 2,364 & 2,955 & 2,954 & 2,570 & 2,830 \\
\hline Governance, rule of law, and human rights & 551 & 802 & 280 & 3,457 & 1,783 & 1,783 & 2,228 & 2,785 & 2,785 & 2,423 & 2,668 \\
\hline Infrastructure and natural resources & 6,235 & 13,001 & 5,479 & 35,401 & 17,163 & 17,850 & 22,312 & 27,891 & 33,469 & 36,807 & 40,524 \\
\hline Education & 1,035 & 1,786 & 1,258 & 8,877 & 3,801 & 3,953 & 4,941 & 6,177 & 7,412 & 8,895 & 9,793 \\
\hline Health & 991 & 2,061 & 838 & 5,392 & 2,834 & 2,834 & 3,542 & 4,428 & 5,314 & 6,376 & 7,020 \\
\hline Agriculture and rural development & 10,170 & 12,031 & 6,125 & 19,090 & 13,714 & 14,262 & 17,828 & 22,285 & 24,513 & 26,965 & 29,688 \\
\hline Social protection & 30 & 33 & 62 & 1,513 & 107 & 107 & 134 & 167 & 201 & 241 & 265 \\
\hline Economic governance and private sector development & 956 & 1,133 & 375 & 10,290 & 2,803 & 2,803 & 3,503 & 4,379 & 5,255 & 5,781 & 6,365 \\
\hline Operating budget balance (excluding grants) & $-11,688$ & $-14,658$ & $-4,435$ & $-19,027$ & $-17,874$ & $-17,608$ & $-18,900$ & $-21,082$ & $-13,445$ & $-7,045$ & 860 \\
\hline Operating budget balance (including grants) & 5,044 & 4,555 & 1,469 & 5,023 & 5,442 & 6,009 & 5,692 & 2,150 & 3,615 & 6,550 & 10,576 \\
\hline Core budget balance (including grants) & 3,206 & $-11,075$ & 2,837 & $-21,909$ & $-12,726$ & $-12,680$ & $-13,638$ & $-18,133$ & $-17,076$ & $-16,865$ & $-16,195$ \\
\hline Float and adjustment $5 /$ & $-1,989$ & 1,235 & 70 & $\ldots$ & 0 & 0 & 0 & 0 & 0 & 0 & 0 \\
\hline Sale of nonfinancial assets 6 / & 1,986 & 2,317 & 40 & 1,002 & 1,002 & 100 & 1,502 & 1,502 & 501 & 0 & 0 \\
\hline Financing & $-3,203$ & 7,523 & $-2,947$ & 20,907 & 11,724 & 12,580 & 12,135 & 16,630 & 16,575 & 16,865 & 16,195 \\
\hline External loans (net) & 5,318 & 6,132 & 1,981 & $\ldots$ & 7,021 & 6,379 & 6,057 & 7,628 & 11,352 & 10,493 & 11,474 \\
\hline Domestic (net) $7 /$ & $-8,521$ & 1,391 & $-4,929$ & $\ldots$ & 4,703 & 6,201 & 6,078 & 9,002 & 5,223 & 6,372 & 4,721 \\
\hline \multicolumn{12}{|l|}{ Memorandum items: } \\
\hline \multicolumn{12}{|l|}{ Before HIPC } \\
\hline Amortization due (excluding IMF, including stock relief, excluding arrears) & $\ldots$ & 190 & $\ldots$ & $\ldots$ & $\ldots$ & 196 & 201 & 185 & 169 & 177 & 269 \\
\hline Interest due (including IMF, including stock relief, excluding arrear & $\ldots$ & 542 & $\ldots$ & $\ldots$ & $\ldots$ & 2,756 & 2,834 & 432 & 539 & 614 & 766 \\
\hline Flow relief (HIPC, MDRI and beyond) & $\ldots$ & & $\ldots$ & $\ldots$ & $\ldots$ & & & & & & 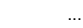 \\
\hline Amortization due (cash, excluding IMF) & $\ldots$ & 0 & $\ldots$ & $\ldots$ & $\ldots$ & 102 & 148 & 151 & 153 & 153 & 225 \\
\hline Interest due (cash) & $\ldots$ & 182 & $\ldots$ & $\ldots$ & $\ldots$ & 2,438 & 2,492 & 88 & 89 & 87 & 121 \\
\hline HIPC and MDRI stock relief & $\cdots$ & 1,474 & $\cdots$ & $\ldots$ & $\cdots$ & 520,009 & 0 & 53,533 & 0 & 0 & 0 \\
\hline Fuel Subsidy to DABM & $\cdots$ & 2,176 & $\ldots$ & $\ldots$ & 3,141 & 3,141 & 2,841 & 2,591 & 2,091 & $\ldots$ & ... \\
\hline Noncash transaction (fuel in kind) & $\ldots$ & & $\ldots$ & $\ldots$ & & 1500 & & & $\ldots$ & $\ldots$ & $\ldots$ \\
\hline External budget (direct donor expenditure) 8/ & 180,583 & 195,035 & 237,942 & $\ldots$ & 113,451 & 237,942 & 270,393 & 232,164 & 214,346 & 186,111 & 159,587 \\
\hline
\end{tabular}

Sources: Ministry of Finance (MOF); Da Afghanistan Bank (DAB); and Fund staff estimates and projections.

1/ Core budget includes central government domestic revenues, grants, operating and development expenditure, and financing

2/ Funding for operating budget from the multi-donor trust funds: The Afghanistan Reconstruction Trust Fund (recurrent window) and the Law and Order Trust Fund (LOTFA).

3/ Interest due (cash only) reflects rescheduling under enhanced HIPC Initiative.

4/ Government's current program classification based on a simple aggregation of administrative units.

5/ Variation between the fiscal position recorded at MOF and DAB. This discrepancy is partially due to the difference ("float") between checks issued and checks cashed.

6/ In 2005/06 and 2006/07 includes $\$ 40$ million receipt from sale of telecommunications spectrum bandwidth and late overflight payment. From $2007 / 08$ includes sale of land and blds and

privatization receipts.

7/ Net change in government deposits with DAB (excluding provincial branch balances). A positive sign corresponds to a decline in balances.

8/ Estimates from MOF and donors.

CInternational Monetary Fund. Not for Redistribution 
Table 2b. Islamic Republic of Afghanistan: Core Budget, 2005/06-2012/13 1/ (In percent of GDP)

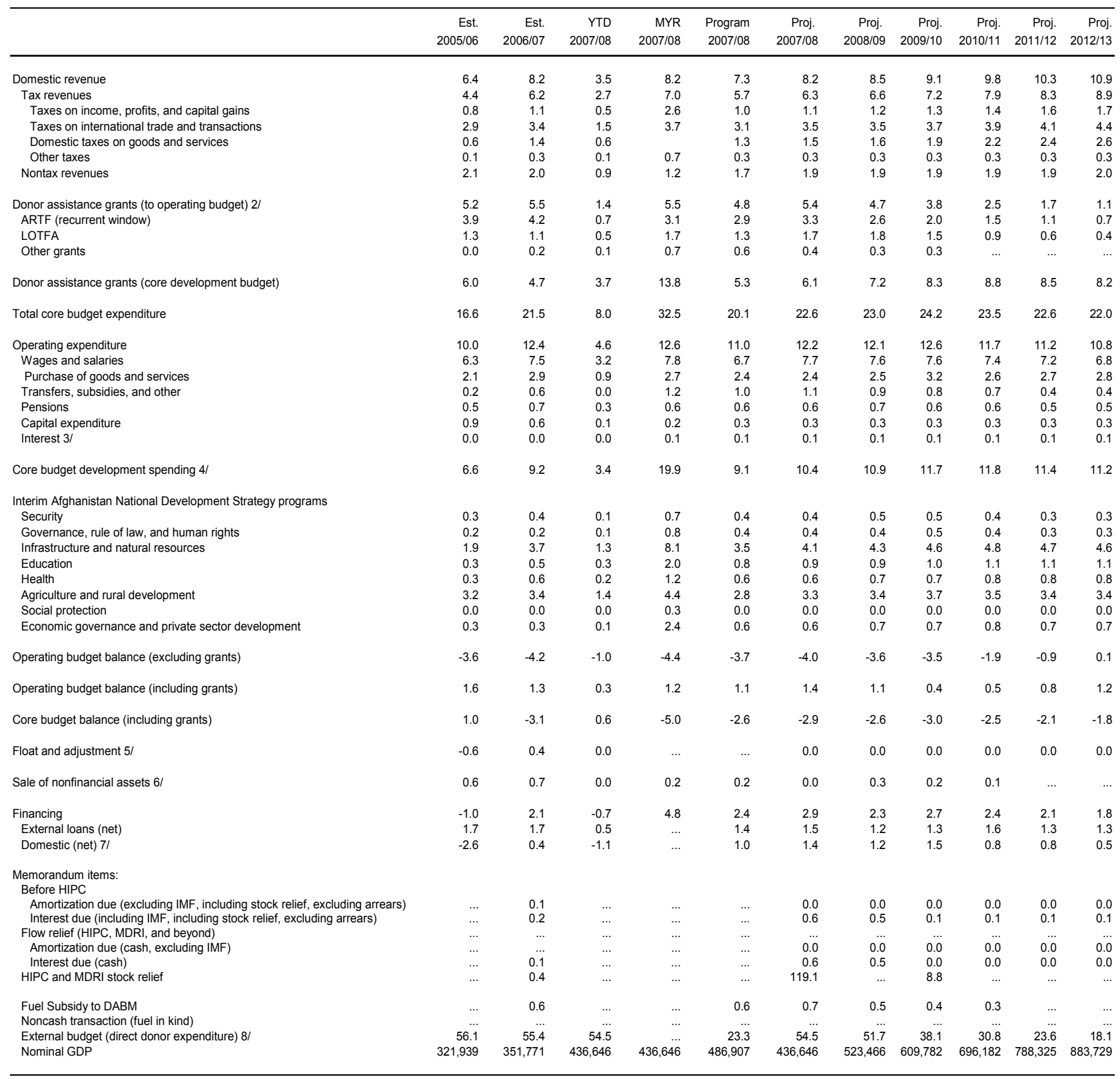

Sources: Ministry of Finance (MOF); Da Afghanistan Bank (DAB); and Fund staff estimates and projections.

1/ Core budget includes central government domestic revenues, grants, operating and development expenditure, and financing

2/ Funding for operating budget from the multi-donor trust funds: The Afghanistan Reconstruction Trust Fund (recurrent window) and the Law and Order Trust Fund (LOTFA).

3/ Interest due (cash only) reflects rescheduling under enhanced HIPC Initiative.

4/ Government's current program classification based on a simple aggregation of administrative units.

5/ Variation between the fiscal position recorded at MoF and DAB. This discrepancy is partially due to the difference ("float") between checks issued and checks cashed.

$6 /$ In 2005/06 and 2006/07 includes $\$ 40$ million receipt from sale of telecommunications spectrum bandwidth and late overflight payment. From 2007/08 includes sale of land and buildings and privatization receipts.

7/ Net change in government deposits with DAB (excluding provincial branch balances). A positive sign corresponds to a decline in balances.

8/ Estimates from MoF and donors. 
Table 3. Islamic Republic of Afghanistan: Balance of Payments, 2005/06-2012/13 (In millions of U.S. dollars; unless otherwise indicated)

\begin{tabular}{|c|c|c|c|c|c|c|c|c|}
\hline & & Est. & & & Projec & ons & & \\
\hline & $2005 / 06$ & $2006 / 07$ & $2007 / 08$ & $2008 / 09$ & $2009 / 10$ & $2010 / 11$ & $2011 / 12$ & $2012 / 13$ \\
\hline Current account (including grants) $1 /$ & -182.5 & -444.0 & -119.2 & -49.7 & -150.1 & -421.9 & -629.0 & -869.3 \\
\hline Current account (excluding grants) & $-4,880.3$ & $-5,435.5$ & $-6,329.9$ & $-7,209.5$ & $-6,843.9$ & $-6,898.1$ & $-6,632.7$ & $-6,429.2$ \\
\hline Trade balance & $-4,335.3$ & $-4,941.6$ & $-5,893.3$ & $-6,765.3$ & $-6,465.3$ & $-6,479.2$ & $-6,186.7$ & $-5,946.7$ \\
\hline Exports of goods (f.o.b.) 2/ & $1,794.8$ & $1,801.3$ & $1,861.2$ & $2,009.8$ & $2,185.0$ & $2,338.8$ & $2,535.6$ & $2,753.2$ \\
\hline Official exports & 385.9 & 416.5 & 474.0 & 596.7 & 728.0 & 874.8 & $1,047.4$ & $1,247.5$ \\
\hline Unofficial exports & $1,408.9$ & $1,384.8$ & $1,387.1$ & $1,413.0$ & $1,457.1$ & $1,464.0$ & $1,488.2$ & $1,505.7$ \\
\hline Smuggling & 173.7 & 149.9 & 136.5 & 137.5 & 134.2 & 129.0 & 123.6 & 117.7 \\
\hline Transit trade & $1,235.2$ & $1,234.9$ & $1,250.6$ & $1,275.5$ & $1,322.9$ & $1,335.0$ & $1,364.7$ & $1,388.0$ \\
\hline Imports of goods (f.o.b.) & $-6,130.1$ & $-6,742.9$ & $-7,754.5$ & $-8,775.0$ & $-8,650.3$ & $-8,818.0$ & $-8,722.4$ & $-8,699.9$ \\
\hline Official imports & $-5,481.7$ & $-6,049.2$ & $-7,140.7$ & $-8,212.0$ & $-8,132.4$ & $-8,348.9$ & $-8,300.3$ & $-8,317.9$ \\
\hline Of which: Duty free & $-3,258.3$ & $-3,579.4$ & $-4,460.8$ & $-5,191.0$ & $-4,730.7$ & $-4,594.1$ & $-4,206.3$ & $-3,856.6$ \\
\hline Smuggling & -648.4 & -693.7 & -613.8 & -563.1 & -517.9 & -469.1 & -422.1 & -382.0 \\
\hline Services and income, net & -545.0 & -493.9 & -436.6 & -444.3 & -378.7 & -418.9 & -446.0 & -482.6 \\
\hline Of which: Interest due 3/ 4/ & -21.2 & -38.8 & -58.3 & -59.8 & -11.8 & -13.9 & -15.5 & -18.6 \\
\hline Current transfers & $4,697.8$ & $4,991.4$ & $6,210.7$ & $7,159.8$ & $6,693.8$ & $6,476.2$ & $6,003.8$ & $5,560.0$ \\
\hline Public & $4,361.1$ & $4,625.4$ & $5,757.8$ & $6,639.6$ & $6,113.8$ & $5,843.0$ & $5,318.4$ & $4,826.0$ \\
\hline Private 5/ & 336.7 & 366.0 & 452.8 & 520.2 & 580.0 & 633.2 & 685.3 & 734.0 \\
\hline Capital and financial account & 356.8 & 194.1 & 22.7 & -109.9 & $-1,275.6$ & 15.1 & 234.7 & 465.4 \\
\hline Debt forgiveness $4 /$ & 0.0 & 0.0 & 0.0 & 0.0 & $-1,069.0$ & 0.0 & 0.0 & 0.0 \\
\hline Foreign direct investment & 271.4 & 237.6 & 289.7 & 346.6 & 417.7 & 540.6 & 627.8 & 726.4 \\
\hline Official loans (net) & 85.4 & 154.9 & 128.6 & 121.2 & 152.5 & 226.8 & 206.5 & 224.6 \\
\hline Disbursement & 101.7 & 163.8 & 132.5 & 125.2 & 156.2 & 230.2 & 210.0 & 230.0 \\
\hline Amortization due 3/ 4/ & -16.3 & -8.8 & -3.9 & -4.0 & -3.7 & -3.4 & -3.5 & -5.4 \\
\hline Commercial banks, net & $\cdots$ & -198.4 & -395.7 & -577.6 & -776.9 & -752.3 & -599.6 & -485.6 \\
\hline Errors and omissions (including short-term capital) & 176.0 & 595.9 & 264.9 & 262.3 & 259.6 & 257.0 & 254.5 & 259.9 \\
\hline Overall balance & 350.3 & 346.0 & 168.3 & 102.7 & $-1,166.1$ & -149.8 & -139.8 & -144.0 \\
\hline Financing & -350.3 & -346.0 & -185.6 & -137.3 & $1,148.7$ & 149.8 & 139.8 & 144.0 \\
\hline Changes in reserve assets of the $\mathrm{DAB}$ & -378.5 & -402.4 & -270.8 & -190.0 & 75.0 & 145.0 & 135.0 & 145.0 \\
\hline Use of Fund resources (net) & 0.0 & 19.8 & 34.4 & 0.0 & 0.0 & 0.0 & 0.0 & -7.9 \\
\hline Exceptional financing & 28.3 & 36.6 & 50.7 & 52.7 & $1,073.7$ & 4.8 & 4.8 & 6.9 \\
\hline Arrears 6/ & -1.1 & -110.1 & $-11,169.4$ & 0.0 & 0.0 & 0.0 & 0.0 & 0.0 \\
\hline Debt rescheduling $7 /$ & 0.0 & 117.2 & 836.5 & 52.7 & 4.8 & 4.8 & 4.8 & 6.9 \\
\hline Of which: Capitalization of interest & 0.0 & 3.6 & 47.4 & 48.0 & 0.0 & 0.0 & 0.0 & 0.0 \\
\hline Multilateral HIPC assistance & 0.0 & 0.0 & 3.3 & 4.7 & 4.8 & 4.8 & 4.8 & 6.9 \\
\hline Debt forgiveness 4/ & 29.4 & 29.5 & $10,383.6$ & 0.0 & $1,069.0$ & 0.0 & 0.0 & 0.0 \\
\hline Of which: HIPC & 0.0 & 0.0 & 0.0 & 0.0 & 447.5 & 0.0 & 0.0 & 0.0 \\
\hline MDRI & 0.0 & 0.0 & 0.0 & 0.0 & 34.7 & 0.0 & 0.0 & 0.0 \\
\hline Financing gap & 0.0 & 0.0 & -17.3 & -34.6 & -17.4 & 0.0 & 0.0 & 0.0 \\
\hline Identified financing (provisional) & 0.0 & 0.0 & 17.3 & 34.6 & 17.4 & 0.0 & 0.0 & 0.0 \\
\hline Of which: IMF PRGF & 0.0 & 0.0 & 17.3 & 34.6 & 17.4 & 0.0 & 0.0 & 0.0 \\
\hline Remaining gap & 0.0 & 0.0 & 0.0 & 0.0 & 0.0 & 0.0 & 0.0 & 0.0 \\
\hline Memorandum Items: & & & & & & & & \\
\hline Gross international reserves & $1,661.8$ & $2,064.2$ & $2,335.0$ & $2,525.0$ & $2,450.0$ & $2,305.0$ & $2,170.0$ & $2,025.0$ \\
\hline (In months of imports) $8 /$ & 7.7 & 9.3 & 9.4 & 9.2 & 8.0 & 6.9 & 5.9 & 5.1 \\
\hline (Relative to external debt service due) & 44.3 & 43.3 & 37.5 & 39.6 & 157.9 & 133.0 & 114.1 & 63.6 \\
\hline (Relative to commercial bank foreign currency liabilities) & 2.6 & 1.9 & 2.7 & 3.6 & 5.0 & 4.4 & 3.2 & 2.6 \\
\hline Trade balance (percent of GDP) & -66.9 & -70.1 & -67.6 & -64.7 & -53.1 & -46.6 & -39.3 & -33.7 \\
\hline Current account balance (percent of GDP) & & & & & & & & \\
\hline Including grants & -2.8 & -6.3 & -1.4 & -0.5 & -1.2 & -3.0 & -4.0 & -4.9 \\
\hline Excluding grants & -75.3 & -77.1 & -72.6 & -69.0 & -56.2 & -49.6 & -42.1 & -36.4 \\
\hline Private sector current account balance (percent of GDP) & & & & & & & & \\
\hline Including grants & -19.8 & -21.1 & -16.2 & -14.3 & -12.6 & -12.0 & -11.1 & -10.4 \\
\hline Excluding grants & -25.0 & -26.3 & -21.4 & -19.3 & -17.4 & -16.6 & -15.4 & -14.6 \\
\hline Total debt service (percent of exports) $9 / 10 /$ & 5.7 & 1.6 & 1.5 & 1.2 & 1.0 & 1.0 & 1.3 & 1.4 \\
\hline Total debt stock (percent of GDP) 9/ & 184.2 & 170.9 & 21.6 & 20.0 & 10.0 & 10.3 & 10.4 & 10.6 \\
\hline
\end{tabular}

Sources: Afghan authorities; and Fund staff estimates and projections.

$1 /$ Numbers have been revised as a result of more reliable data on public grants.

2/ Excludes opium exports and, due to limited data availability, flows associated with U.S. Army and most ISAF activities.

3/ Debt service projections are based on the total stock of external debt (including estimates of unverified arrears). Given lack of data on the rate of penalty interest and ongoing bilateral negotiations, interest on overdue obligations was estimated by Fund staff.

4/ Assumes that Afghanistan will reach the completion point under the enhanced HIPC initiative and receive MDRI relief from IDA in 2009/10. Paris Club creditors are assumed to go beyond HIPC and provide 100 percent stock reduction on eligible debts and capitalized interest at completion point.

$5 /$ Includes foreign transactions recently reported by licensed money changers.

6/ Arrears shown represent Fund staff estimates of debt service due, but not paid, on estimated overdue obligations. The 2006/07 and 2007/08 reduction in arrears corresponds principally to the July 2006 rescheduling of Paris Club debt on Naples terms, including the upfront cancellation of the majority of Russian claims consistent with Paris Club practice.

7/ Debt rescheduling includes the capitalization of interest falling due to Paris Club creditors until the completion point of the enhanced HIPC Initiative, interim assistance from multilateral creditors, and HIPC debt relief from multilateral creditors after the completion point.

$8 /$ In months of imports of goods and services, excluding imports for reexports and duty free imports by donors. The definition of imports used for the calculation of reserve coverage has been changed to exclude duty free imports by donors that are fully financed.

9/ After HIPC and MDRI relief as well as debt relief beyond HIPC from Paris Club creditors. Debt includes obligations to the IMF. The debt stock includes the capitalization of interest to Paris Club creditors until completion point of the enhanced HIPC initiative.

10/ Exports exclude reexports. 
Table 4. Islamic Republic of Afghanistan: Monetary Program (Da Afghanistan Bank), 2005/06-2008/09 1/

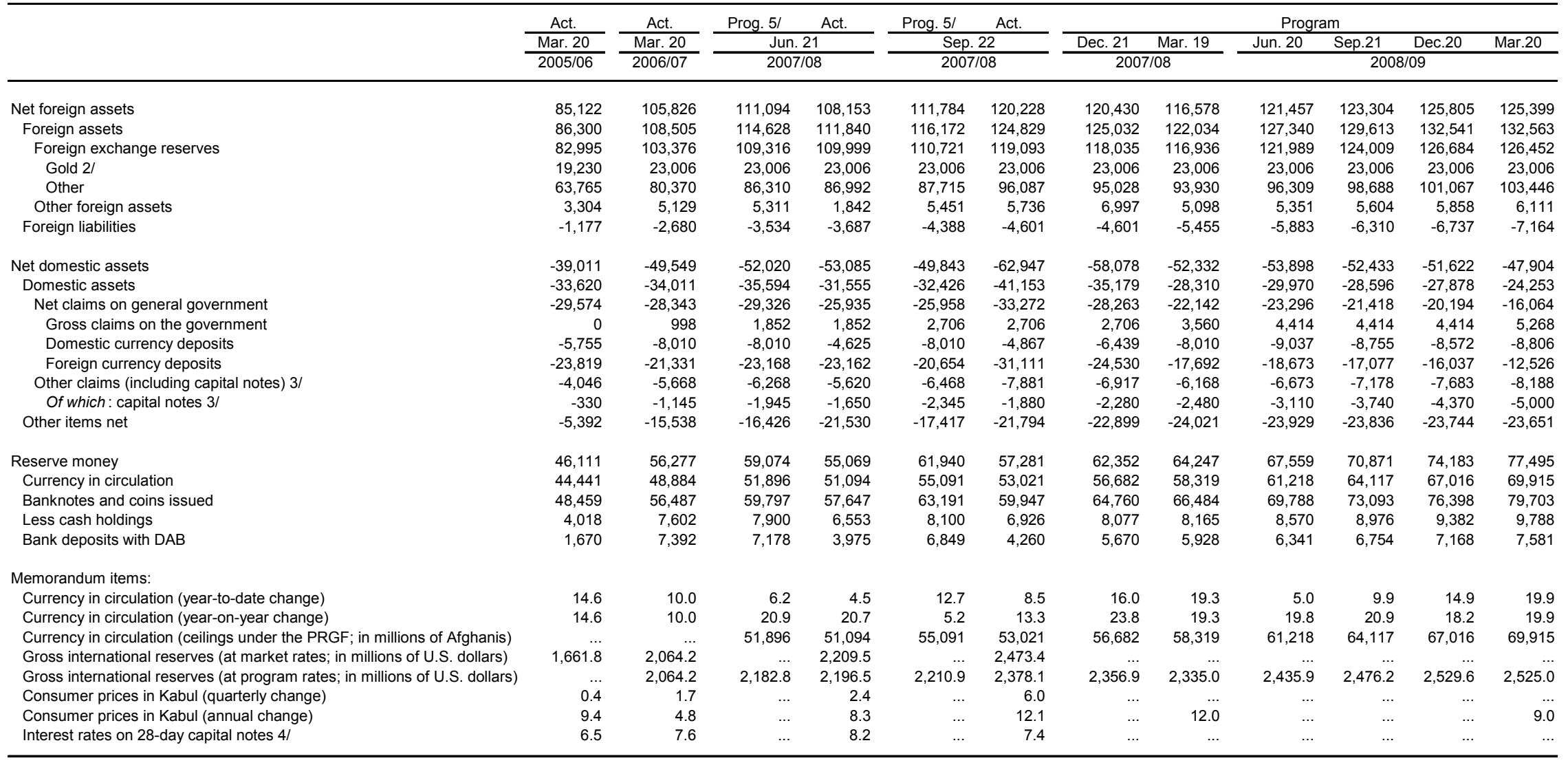

Sources: Da Afghanistan Bank (DAB) and Central Statistics Office; and Fund staff estimates and projections.

1/ 2004/05-2006/07 figures are estimated using market exchange rates. 2007/08 estimates and program projections are made on the basis of the program exchange rate. 2/ The gold does not include the gold held in the palace vaults.

3/ Until March 2006, capital notes and foreign currency deposits of commercial banks with DAB were included in Reserve money (as banks could use capital notes to meet their reserve requirements:

this possibility was removed in March 2006, at which time banks were also instructed to meet the reserve requirements in Afghanis only against both Afghani and foreign currency deposits).

2006.

$5 /$ The second PRGF review projection is re-based due to revised estimates of foreign reserves and currency in circulation data (no consequence for the assessment of program performance in 2006/07). 
Table 5. Islamic Republic of Afghanistan: External Financing Requirement and Sources, 2005/06-2012/13 (In millions of U.S. dollars)

\begin{tabular}{|c|c|c|c|c|c|c|c|c|}
\hline & \multirow{2}{*}{$\begin{array}{r}\text { Est. } \\
2005 / 06\end{array}$} & \multirow{2}{*}{$\begin{array}{r}\text { Prel. Est. } \\
2006 / 07\end{array}$} & \multicolumn{6}{|c|}{ Projections } \\
\hline & & & $2007 / 08$ & $2008 / 09$ & $2009 / 10$ & $2010 / 11$ & $2011 / 12$ & $2012 / 13$ \\
\hline I. Total financing requirement & $5,276.2$ & $5,956.8$ & $17,773.9$ & $7,403.6$ & $7,841.6$ & $6,756.5$ & $6,501.3$ & $6,297.5$ \\
\hline Current account (excluding grants) & $4,880.3$ & $5,435.5$ & $6,329.9$ & $7,209.5$ & $6,843.9$ & $6,898.1$ & $6,632.7$ & $6,429.2$ \\
\hline Amortization & 16.3 & 8.8 & 3.9 & 4.0 & 3.7 & 3.4 & 3.5 & 13.3 \\
\hline Of which: IMF & 0.0 & 0.0 & 0.0 & 0.0 & 0.0 & 0.0 & 0.0 & 7.9 \\
\hline Prepayment of debt & 0.0 & 0.0 & 0.0 & 0.0 & $1,069.0$ & 0.0 & 0.0 & 0.0 \\
\hline Change in reserves (increase $=+$ ) & 378.5 & 402.4 & 270.8 & 190.0 & -75.0 & -145.0 & -135.0 & -145.0 \\
\hline Reduction in arrears & 1.1 & 110.1 & $11,169.4$ & 0.0 & 0.0 & 0.0 & 0.0 & 0.0 \\
\hline II. Available financing & $5,276.2$ & $5,956.8$ & $17,756.7$ & $7,368.9$ & $7,824.2$ & $6,756.5$ & $6,501.3$ & $6,297.5$ \\
\hline Current transfers & $4,697.8$ & $4,991.4$ & $6,210.7$ & $7,159.8$ & $6,693.8$ & $6,476.2$ & $6,003.8$ & $5,560.0$ \\
\hline Foreign direct investment & 271.4 & 237.6 & 289.7 & 346.6 & 417.7 & 540.6 & 627.8 & 726.4 \\
\hline Short-term private financing flows & . & -198.4 & -395.7 & -577.6 & -776.9 & -752.3 & -599.6 & -485.6 \\
\hline Official medium- and long-term loans & 101.7 & 163.8 & 132.5 & 125.2 & 156.2 & 230.2 & 210.0 & 230.0 \\
\hline IMF disbursements & 0.0 & 19.8 & 34.4 & 0.0 & 0.0 & 0.0 & 0.0 & 0.0 \\
\hline Debt forgiveness & 29.4 & 29.5 & $10,383.6$ & 0.0 & $1,069.0$ & 0.0 & 0.0 & 0.0 \\
\hline Debt rescheduling & 0.0 & 117.2 & 836.5 & 52.7 & 4.8 & 4.8 & 4.8 & 6.9 \\
\hline Other & 176.0 & 595.9 & 264.9 & 262.3 & 259.6 & 257.0 & 254.5 & 259.9 \\
\hline Required financing $=|-| \mid$ & 0.0 & 0.0 & 17.3 & 34.6 & 17.4 & 0.0 & 0.0 & 0.0 \\
\hline Financing gap & 0.0 & 0.0 & 17.3 & 34.6 & 17.4 & 0.0 & 0.0 & 0.0 \\
\hline Identified financing (provisional) & 0.0 & 0.0 & 17.3 & 34.6 & 17.4 & 0.0 & 0.0 & 0.0 \\
\hline Of which: IMF PRGF & 0.0 & 0.0 & 17.3 & 34.6 & 17.4 & 0.0 & 0.0 & 0.0 \\
\hline Remaining gap & 0.0 & 0.0 & 0.0 & 0.0 & 0.0 & 0.0 & 0.0 & 0.0 \\
\hline
\end{tabular}

Sources: Data provided by the Afghan authorities; and Fund staff estimates and projections. 
Table 6. Islamic Republic of Afghanistan: Projected Payments to the Fund as of November 30, 2007 (In millions of SDRs)

\begin{tabular}{|c|c|c|c|c|c|c|c|c|c|c|}
\hline & $20071 /$ & 2008 & 2009 & 2010 & 2011 & 2012 & 2013 & 2014 & Beyond & Total \\
\hline \multicolumn{11}{|l|}{ Obligations from existing drawings } \\
\hline GRA repurchases & 0.0 & 0.0 & 0.0 & 0.0 & 0.0 & 0.0 & 0.0 & 0.0 & 0.0 & 0.0 \\
\hline PRGF repayments & 0.0 & 0.0 & 0.0 & 0.0 & 0.0 & 2.5 & 7.2 & 7.2 & 19.0 & 35.8 \\
\hline \multicolumn{11}{|l|}{ 2. Charges and interest $2 /$} \\
\hline SDR assesments & 0.0 & 0.0 & 0.0 & 0.0 & 0.0 & 0.0 & 0.0 & 0.0 & 0.0 & 0.0 \\
\hline SDR charges & 0.0 & 0.9 & 0.9 & 0.9 & 0.9 & 0.9 & 0.9 & 0.9 & 4.7 & 11.3 \\
\hline \multirow{2}{*}{$\begin{array}{l}\text { Total obligations } \\
\text { (percent of quota) }\end{array}$} & 0.1 & 1.1 & 1.1 & 1.1 & 1.1 & 3.6 & 8.2 & 8.2 & 23.9 & 48.5 \\
\hline & 0.1 & 0.7 & 0.7 & 0.7 & 0.7 & 2.2 & 5.1 & 5.1 & 14.7 & 29.9 \\
\hline \multicolumn{11}{|l|}{ Obligations from prospective drawings $3 /$} \\
\hline \multicolumn{11}{|l|}{ 1. Principal } \\
\hline \multicolumn{11}{|l|}{ 2. Charges and interest $2 /$} \\
\hline PRGF interest & 0.0 & 0.1 & 0.2 & 0.2 & 0.2 & 0.2 & 0.2 & 0.2 & 0.3 & 1.8 \\
\hline Total obligations & 0.0 & 0.1 & 0.2 & 0.2 & 0.2 & 0.2 & 2.5 & 7.0 & 36.5 & 47.0 \\
\hline (percent of quota) & 0.0 & 0.1 & 0.1 & 0.1 & 0.1 & 0.1 & 1.5 & 4.3 & 22.5 & 29.0 \\
\hline \multicolumn{11}{|l|}{$\begin{array}{l}\text { Cumulative obligations } \\
\text { (existing and prospective) }\end{array}$} \\
\hline \multicolumn{11}{|l|}{ 1. Principal } \\
\hline GRA repurchases & 0.0 & 0.0 & 0.0 & 0.0 & 0.0 & 0.0 & 0.0 & 0.0 & 0.0 & 0.0 \\
\hline PRGF repayments & 0.0 & 0.0 & 0.0 & 0.0 & 0.0 & 2.5 & 9.4 & 13.9 & 55.2 & 81.0 \\
\hline \multicolumn{11}{|l|}{ 2. Charges and interest $2 /$} \\
\hline PRGF interest & 0.1 & 0.3 & 0.4 & 0.4 & 0.4 & 0.4 & 0.4 & 0.3 & 0.4 & 3.1 \\
\hline SDR net charges & 0.0 & 0.9 & 0.9 & 0.9 & 0.9 & 0.9 & 0.9 & 0.9 & 4.7 & 11.3 \\
\hline Total obligations & 0.1 & 1.2 & 1.3 & 1.4 & 1.4 & 3.8 & 10.7 & 15.2 & 60.4 & 95.4 \\
\hline \multicolumn{11}{|l|}{ Memorandum items: } \\
\hline \multicolumn{11}{|l|}{$\begin{array}{l}\text { Outstanding Fund credit } \\
\text { In percent of: }\end{array}$} \\
\hline Exports of goods and services $4 /$ & 4 & 5 & 5 & 4 & 4 & 3 & 2 & 2 & $\ldots$ & $\ldots$ \\
\hline External public debt & 1 & 2 & 4 & 4 & 3 & 3 & 2 & 1 & $\ldots$ & $\ldots$ \\
\hline Gross official reserves & 1 & 1 & 2 & 2 & 2 & 2 & 2 & 1 & $\ldots$ & ... \\
\hline GDP & 0 & 0 & 0 & 0 & 0 & 0 & 0 & 0 & $\ldots$ & $\ldots$ \\
\hline Quota & 22 & 36 & 50 & 50 & 50 & 49 & 43 & 34 & $\ldots$ & $\cdots$ \\
\hline \multirow{2}{*}{\multicolumn{11}{|c|}{$\begin{array}{l}\text { Total Obligations } \\
\text { In percent of: }\end{array}$}} \\
\hline & & & & & & & & & & \\
\hline Exports of goods and services 4/ & 0.0 & 0.1 & 0.1 & 0.1 & 0.1 & 0.1 & 0.3 & 0.4 & $\ldots$ & $\ldots$ \\
\hline External public debt & 0.0 & 0.0 & 0.1 & 0.1 & 0.1 & 0.1 & 0.3 & 0.4 & $\ldots$ & $\ldots$ \\
\hline Gross official reserves & 0.0 & 0.0 & 0.0 & 0.0 & 0.0 & 0.1 & 0.3 & 0.4 & $\ldots$ & $\ldots$ \\
\hline GDP & 0.0 & 0.0 & 0.0 & 0.0 & 0.0 & 0.0 & 0.0 & 0.0 & $\ldots$ & $\ldots$ \\
\hline Quota & 0 & 1 & 1 & 1 & 1 & 2 & 7 & 9 & 37 & 59 \\
\hline
\end{tabular}

Source: Fund staff estimates and projections.

1/ December 1, 2007 to December 31, 2007.

2/ Projections are based on current interest rates for PRGF. The current SDR interest rate is assumed for net use of SDRs.

3/ Based on the proposed level and phasing of access, and subject to Executive Board approval.

4/ Excludes reexports. 
Table 7. Islamic Republic of Afghanistan: Proposed Schedule of Reviews and Disbursements

\begin{tabular}{|c|c|c|c|}
\hline \multirow[b]{2}{*}{ Date } & \multicolumn{2}{|c|}{ Amount of Disbursement } & \multirow[b]{2}{*}{ Conditions } \\
\hline & Millions of SDRs & Percent of Quota 1/ & \\
\hline June 2006 & 13.2 & 8.2 & Approval of arrangement $2 /$ \\
\hline March 2007 & 11.3 & 7.0 & $\begin{array}{l}\text { First review and September } 2006 \\
\text { performance criteria 3/ }\end{array}$ \\
\hline July 2007 & 11.3 & 7.0 & $\begin{array}{l}\text { Second review and March } 2007 \\
\text { performance criteria 4/ }\end{array}$ \\
\hline February 2008 & 11.3 & 7.0 & $\begin{array}{l}\text { Third review and September } 2007 \\
\text { performance criteria }\end{array}$ \\
\hline May 2008 & 11.3 & 7.0 & $\begin{array}{l}\text { Fourth review and March } 2008 \\
\text { performance criteria }\end{array}$ \\
\hline January 2009 & 11.3 & 7.0 & $\begin{array}{l}\text { Fifth review and September } 2008 \\
\text { performance criteria }\end{array}$ \\
\hline May 2009 & 11.3 & 7.0 & $\begin{array}{l}\text { Sixth review and March } 2009 \\
\text { performance criteria }\end{array}$ \\
\hline Total & 81.0 & 50.0 & \\
\hline
\end{tabular}

Source: Fund staff estimates and projections.

1/ Does not sum due to rounding.

2/ Due to domestic legal obstacles, the first disbursement was drawn with a delay, on January 19, 2007.

3/ The first review was concluded on March 7, 2007 and the second disbursement was drawn on March $29,2007$.

4/ The second review was concluded on July 9, 2007 and the third disbursement was drawn on July 23, 2007. 
Table 8. Islamic Republic of Afghanistan: Millennium Development Goals, 1990-2005 1/

\begin{tabular}{|c|c|c|c|c|}
\hline & 1990 & 1995 & 2000 & 2005 \\
\hline \multicolumn{5}{|l|}{ Goal 1: Eradicate extreme poverty and hunger } \\
\hline Income share held by lowest 20 percent & $\ldots$ & $\ldots$ & $\ldots$ & $\ldots$ \\
\hline Malnutrition prevalence, weight for age (percent of children under 5) & $\ldots$ & 49.3 & 41.2 & 39.3 \\
\hline Poverty gap at $\$ 1$ a day (PPP) (percent) & $\ldots$ & $\ldots$ & $\ldots$ & $\ldots$ \\
\hline Poverty headcount ratio at $\$ 1$ a day (PPP) (percent of population) & $\ldots$ & $\ldots$ & $\ldots$ & $\ldots$ \\
\hline Poverty headcount ratio at national poverty line (percent of population) & $\ldots$ & $\ldots$ & $\ldots$ & $\ldots$ \\
\hline Prevalence of undernourishment (percent of population) & $\ldots$ & $\ldots$ & $\ldots$ & $\ldots$ \\
\hline \multicolumn{5}{|l|}{ Goal 2: Achieve universal primary education } \\
\hline Literacy rate, youth total (percent of people ages 15-24) & $\ldots$ & $\ldots$ & $\ldots$ & 34.0 \\
\hline Persistence to grade 5, total (percent of cohort) & $\ldots$ & $\ldots$ & $\ldots$ & ... \\
\hline Primary completion rate, total (percent of relevant age group) & $\ldots$ & 25.0 & $\ldots$ & 32.0 \\
\hline School enrollment, primary (percent net) & $\ldots$ & $\cdots$ & $\ldots$ & $\ldots$ \\
\hline \multicolumn{5}{|l|}{ Goal 3: Promote gender equality and empower women } \\
\hline Proportion of seats held by women in national parliament (percent) & 4.0 & $\ldots$ & $\ldots$ & 27.0 \\
\hline Ratio of girls to boys in primary and secondary education (percent) & $\ldots$ & $\ldots$ & 44.0 & 55.0 \\
\hline Ratio of young literate females to males (percent ages 15-24) & $\ldots$ & $\ldots$ & $\ldots$ & 36.0 \\
\hline Share of women employed in the nonagricultural sector (percent of total nonagricultural employment) & 17.8 & $\ldots$ & $\ldots$ & $\ldots$ \\
\hline \multicolumn{5}{|l|}{ Goal 4: Reduce child mortality } \\
\hline Immunization, measles (percent of children ages $12-23$ months) & 20.0 & 41.0 & 35.0 & 64.0 \\
\hline Mortality rate, infant (per 1,000 live births) & $\ldots$ & $\ldots$ & $\ldots$ & $\ldots$ \\
\hline Mortality rate, under- 5 (per 1,000$)$ & $\ldots$ & $\ldots$ & $\ldots$ & $\ldots$ \\
\hline \multicolumn{5}{|l|}{ Goal 5: Improve maternal health } \\
\hline Births attended by skilled health staff (percent of total) & $\ldots$ & $\ldots$ & 12.0 & 14.0 \\
\hline Maternal mortality ratio (modeled estimate, per 100,000 live births) & $\ldots$ & $\ldots$ & 1900.0 & $\ldots$ \\
\hline \multicolumn{5}{|l|}{ Goal 6: Combat HIVIAIDS, malaria, and other diseases } \\
\hline Contraceptive prevalence (percent of women ages 15-49) & $\ldots$ & $\ldots$ & $\ldots$ & 10.0 \\
\hline Incidence of tuberculosis (per 100,000 people) & 244.0 & 242.0 & 209.0 & 168.0 \\
\hline Prevalence of HIV, female (percent ages 15-24) & $\ldots$ & $\ldots$ & $\ldots$ & $\ldots$ \\
\hline Prevalence of HIV, total (percent of population ages 15-49) & $\ldots$ & $\ldots$ & $\ldots$ & 0.1 \\
\hline Tuberculosis cases detected under DOTS (percent) & $\ldots$ & 3.0 & 13.0 & 44.0 \\
\hline \multicolumn{5}{|l|}{ Goal 7: Ensure environmental sustainability } \\
\hline CO2 emissions (metric tons per capita) & 0.2 & 0.1 & 0.0 & 0.0 \\
\hline Forest area (percent of land area) & 2.0 & $\ldots$ & 2.0 & 1.0 \\
\hline GDP per unit of energy use (constant 2000 PPP \$ per kg of oil equivalent) & $\ldots$ & $\ldots$ & $\ldots$ & $\ldots$ \\
\hline Improved sanitation facilities (percent of population with access) & 3.0 & $\ldots$ & $\ldots$ & 34.0 \\
\hline Improved water source (percent of population with access) & 4.0 & $\ldots$ & $\ldots$ & 39.0 \\
\hline Nationally protected areas (percent of total land area) & $\ldots$ & $\ldots$ & $\ldots$ & 0.3 \\
\hline \multicolumn{5}{|l|}{ Goal 8: Develop a global partnership for development } \\
\hline Aid per capita (current US\$) & 11.0 & $\ldots$ & $\ldots$ & $\ldots$ \\
\hline Debt service (PPG and IMF only, percent of exports of G\&S, excl. workers' remittances) & $\ldots$ & $\ldots$ & $\ldots$ & $\ldots$ \\
\hline Fixed line and mobile phone subscribers (per 1,000 people) & 2.0 & 1.0 & 1.0 & 44.0 \\
\hline Internet users (per 1,000 people) & 0.0 & $\ldots$ & 0.0 & 1.0 \\
\hline Personal computers (per 1,000 people) & $\ldots$ & $\ldots$ & $\ldots$ & $\ldots$ \\
\hline Total debt service (percent of exports of goods, services and income) & $\ldots$ & $\ldots$ & $\ldots$ & $\ldots$ \\
\hline Unemployment, youth female (percent of female labor force ages 15-24) & $\ldots$ & $\ldots$ & $\ldots$ & $\ldots$ \\
\hline Unemployment, youth male (percent of male labor force ages 15-24) & $\ldots$ & $\ldots$ & $\ldots$ & $\ldots$ \\
\hline Unemployment, youth total (percent of total labor force ages 15-24) & $\ldots$ & $\ldots$ & $\ldots$ & $\ldots$ \\
\hline \multicolumn{5}{|l|}{ Other } \\
\hline Fertility rate, total (births per woman) & $\ldots$ & $\ldots$ & $\ldots$ & $\ldots$ \\
\hline GNI per capita, Atlas method (current US\$) & $\ldots$ & $\ldots$ & $\ldots$ & $\ldots$ \\
\hline GNI, Atlas method (current US\$) (billions) & $\ldots$ & $\ldots$ & $\ldots$ & 7.0 \\
\hline Gross capital formation (percent of GDP) & $\ldots$ & $\ldots$ & 28.1 & 25.0 \\
\hline Life expectancy at birth, total (years) & $\ldots$ & $\ldots$ & $\ldots$ & $\ldots$ \\
\hline Literacy rate, adult total (percent of people ages 15 and above) & $\ldots$ & $\ldots$ & $\ldots$ & 28.0 \\
\hline Population, total (millions) & 14.0 & $\ldots$ & $\ldots$ & $\ldots$ \\
\hline Trade (percent of GDP) & $\ldots$ & $\ldots$ & 99.1 & 68.1 \\
\hline
\end{tabular}

Sources: Data provided by the Afghan authorities; World Development Indicators database (2007); and Fund staff estimates and projections.

1 / When data for a particular year is missing, the value reported corresponds to the closest year where data for that indicator is available. 


\section{ATTACHMENT I. LETTER OF INTENT}

Kabul, January 28, 2008

Mr. Dominique Strauss-Kahn

Managing Director

International Monetary Fund

Washington, D.C. 20431

Dear Mr. Strauss-Kahn,

The attached Memorandum of Economic and Financial Policies (MEFP) supplements and updates the understandings reached with IMF staff on our economic program supported by the Poverty Reduction and Growth Facility (PRGF) Arrangement. The new MEFP reports on quantitative performance through September 2007 and on progress in implementing Afghanistan's structural reform agenda. It sets quantitative targets through September 2008, including quantitative performance criteria for March 2008, and describes the government's policies for the remainder of fiscal year 2007/08 (ending on March 20, 2008) and, on a preliminary basis, for 2008/09.

We are pleased to inform you that we met all the September 2007 quantitative performance criteria, including the floor on fiscal revenue, which required redoubled efforts to strengthen revenue administration, and broaden the collection base. We also observed the continuous zero ceilings on contracting or guaranteeing of new medium- and long-term nonconcessional external debt, on short-term external debt, and on new lending from state-owned banks to, or government-guaranteed borrowing by, enterprises in need of restructuring; and the continuous performance criterion prohibiting accumulation of new external payments arrears. The program, centered on fiscal discipline and maintaining confidence in the Afghani, contributed to limiting inflationary pressures and strengthening our external position.

Regarding the structural conditionality for the third review, we have experienced some delays in implementing several measures. Some of the delays are not critical for the achievement of program objectives and call for corrective actions we are ready to implement. We request a waiver of nonobservance for the structural performance criterion on submitting to parliament the core budget's audited financial statement for 2006/07 by September 21, 2007. By making the submission one day later, on September 22, 2007 we have observed the Public Finance and Expenditure Management Law. We missed the structural benchmark requiring Cabinet's adoption of a comprehensive restructuring plan for the public entities and government agencies engaged in commercial activities, but not covered by the State Owned Enterprises law. We will make our best efforts to obtain Cabinet approval of this plan (currently under preparation) before end-March 2008. We also missed two structural benchmarks for end-November 2007 calling for the issuance of regulations on credit-granting standards and the credit-monitoring process, and setting limits on sector loan concentration.

As required by law, draft regulations have been issued to the public for comments. We intend to obtain DAB's Supreme Council final approval of both regulations and issue them in early 
February 2008. We have implemented partially the structural benchmark on submitting for Cabinet approval, by August 31, 2007, a restructuring plan for Bank Pashtany, based on the bank's audited financial statement. We made the submission before the required test date but, as the audit of the financial statements of the bank had not yet been finalized at that time, the restructuring plan did not fully benefit from its findings. Once the audit is finalized, the restructuring plan for Bank Pashtany will be amended to take the audit into account. All other structural benchmarks were met. We remain in consultation with IMF staff to ensure satisfactory implementation of the program.

The government and Da Afghanistan Bank (DAB) believe that the economic and financial policies set forth in the attached memorandum provide a sound basis for achieving the objectives and targets of the program. During the period of the arrangement, we will consult with the Fund on the adoption of any further measures that may be appropriate, at the initiative of the government or DAB, or whenever the Managing Director of the IMF requests such a consultation. In addition, we will provide the Fund in a timely manner with all information necessary to monitor implementation of the program. The government and DAB will conduct with the Fund the fourth review before end-July 2008.

On the basis of this performance, and on the strength of the policies set forth in the attached memorandum, we request that the IMF complete the third review under the PRGF arrangement and approve the fourth disbursement (in the amount of SDR 11.3 million). After the period of this arrangement and while Afghanistan has outstanding financial obligations to the IMF, we will periodically consult with the IMF, at the initiative of the government or DAB, or whenever the Managing Director of the IMF requests consultation on Afghanistan's economic and financial policies.

We remain committed to transparent policy-making and are keen on rendering the contents of this letter and those of the attached MEFP and technical memorandum of understanding, as well as the staff report for the 2007Article IV consultation and third review under the PRGF arrangement, available to the public and hereby authorize their posting on the Fund's website subsequent to Executive Board consideration of this request.

Sincerely yours,

Anwar Ul-Haq Ahady

Minister of Finance

Ministry of Finance

$/ \mathrm{s} /$
Abdul Qadeer Fitrat Governor

Da Afghanistan Bank

/s/ 


\section{Attachment II. Memorandum of Economic and Financial Policies}

FOR THE REMAINDER OF 2007/08 AND 2008/09

January 28, 2008

\section{INTRODUCTION}

1. The Government of the Islamic Republic of Afghanistan and Da Afghanistan Bank (DAB) remain committed to the program of economic reforms aimed at reducing poverty and moving Afghanistan to a sustainable growth path. This memorandum reviews quantitative performance through September 2007 and compliance with structural conditionality for the third review under the program supported by the Poverty Reduction and Growth Facility (PRGF) arrangement, sets out the revised economic and financial policies for the remainder of 2007/08, outlines the government's policy commitments for 2008/09, and updates Afghanistan's medium-term objectives and policy framework. Based on these policies, we request completion of the third review and approval of the fourth disbursement under the PRGF arrangement.

\section{A. Performance Under the Program}

2. Economic developments in $\mathbf{2 0 0 7 / 0 8}$ have been marked by high economic growth and a return of inflation to double-digit levels. A rebound in agricultural production from the drought-triggered decline in 2006/07 and strong growth in other sectors, particularly services, are expected to raise GDP by $13 \frac{1}{2}$ percent in 2007/08. Higher prices for imported fuel and foodstuffs caused the Kabul CPI to increase by 8 percent in the first seven months of 2007/08, with 12-month (end-of-period) inflation peaking above 12 percent in September 2007 before subsiding to $9 \frac{1}{2}$ percent in October 2007. Despite the increase in inflation, the exchange rate of the Afghani has remained stable against the U.S. dollar.

3. Performance under the financial program through September 2007 was strong. Despite a slow start in the early months of 2007/08, fiscal revenue exceeded the program floor for the first half of the year by 3.4 percent (about 0.1 percent of GDP). All other quantitative performance criteria and the indicative ceiling on the operating budget deficit (excluding grants) were observed with ample margins (Table 1). The observance of the fiscal policy targets reflected mainly the consolidation of administrative efforts to increase fiscal revenue and a prudent implementation of operating expenditure. The maintenance of an appropriate monetary policy stance was instrumental to meeting the performance criteria on net international reserves and currency in circulation.

4. We have also followed through on the structural conditionality for the third review but experienced delays in implementing several measures (Table 2). We submitted to parliament the core budget's audited financial statement for 2006/07 on September 22, 2007 - the last day of the sixth month of the Afghan solar year 1386 - and thus observed the 
Public Finance and Expenditure Management Law; however, we missed the September 21, 2007 test date for the related structural performance criterion. We missed the structural benchmark for end-September 2007 calling for the adoption by the Cabinet of a comprehensive restructuring plan for the public enterprises not covered by the law on state-owned enterprises (SOEs) - Tassady Law. The implementation of this measure has been delayed several times for technical reasons (lack of capacity) and the absence of broad support for the privatization of these enterprises, including among the members of the Cabinet. Nevertheless, the plan remains under preparation and we will make our best efforts to obtain Cabinet approval by March 31, 2008. We also missed two structural benchmarks for end-November 2007 calling for the issuance of regulations on credit-granting standards and the credit-monitoring process and setting limits on sector loan concentration. As required by law, draft regulations have been submitted to public for comments and we intend to obtain DAB's Supreme Council final approval of both regulations and issue them in early February 2008. We have implemented partially the structural benchmark on submitting, by August 31, 2007, for Cabinet approval a restructuring plan for Bank Pashtany, based on the bank's audited financial statement. We made the submission before the required test date, although the audit of the bank's financial statement has not yet been completed. We have met all other structural benchmarks. We have also made significant progress toward implementing, the understandings reached with Fund staff in July 2007 with regard to the elimination of the discretionary application of a 1 percent import tariff rate on raw materials and other intermediate inputs.

\section{B. Fiscal Sector}

\section{Fiscal performance during the first half of 2007/08 was stronger than}

programmed. The revenue target for the first half of 2007/08 (equivalent to 3.4 percent of revised annual GDP) was comfortably met, and operating expenditure was below the programmed level by 1.1 percent of GDP, in part due to the delayed approval of the budget. As a result, the operating budget deficit (excluding grants) for the first half of 2007/08 is estimated at 1.0 percent of GDP, compared to an indicative program target of 2.0 percent. Lower than expected external grants for the operating budget were largely offset by higher grants for the development budget. Core development budget expenditure, at 3.4 percent of GDP, was in line with the program

\section{Improvements in revenue collection allowed us to exceed the midyear revenue}

target. In particular, collections of the business receipts tax (BRT) improved significantly relative to last year as a result of vigorous compliance and enforcement campaigns on telecommunication services providers, hotels, and banks by the Large Taxpayers Office (LTO), and on restaurants and wedding halls by the interim Medium Taxpayers Office (MTO). Advance remittance of overflight revenues in the second quarter led to better than expected collection of administrative fees, although this revenue will not be available for collection in the fourth quarter. Customs duty receipts were lower than expected, probably reflecting ongoing changes to the tariff regime, but higher nonduty customs collections, including a 2 percent advance payment of income tax, compensated for the revenue shortfall. 
7. New information on the external budget, particularly on security outlays, indicates that direct donor-financed expenditures have been significantly higher than previously estimated. Our international security partners have shared new information with us on the magnitude of external security spending. Based on this information, our projection for external budget spending in 2007/08 has increased by Af 124 billion (about 29 percent of GDP). Much of the new data are presented on commitment basis, and we will seek to improve our estimate of the cash impact of this spending on the Afghan economy over the coming months.

8. Progress has continued on structural reforms in the public finances. We met the end-July 2007 structural benchmark on clarifying the tax policy framework and published the document to this effect. Nevertheless, we continue to hear about confusion among some tax payers and there have been some cases of misclassification of "traders" by our own officials. The Afghanistan Investment Support Agency (AISA) and the Revenue Department of the Ministry of Finance (MOF) intend to conduct a public information campaign to rectify this. We have also taken steps to address staff shortages in the revenue department, published a document that clarifies the roles and responsibilities of the various agencies operating at the border, and transferred accountability for all large- and medium-sized taxpayers in Kabul, on a pilot basis, to the revenue department. In addition, we have submitted to parliament legislation amending the income tax law and will soon submit a proposal to apply the BRT to imports - a key step in the gradual transition toward a broad-based consumption tax.

9. We continue to strengthen our Medium-Term Fiscal Framework (MTFF) in line with the commitments made at the time of the second program review. The MTFF is increasingly being used as a tool for engaging donors to discuss external support for the recurrent budget. We are also setting out the levels of public investment needed to create enabling conditions for the implementation of the Afghan National Development Strategy (ANDS). The latest version of the MTFF is consistent with the PRGF and is part of our baseline macro-framework for the ANDS.

\section{Monetary and Financial Sector}

10. Monetary policy has remained broadly consistent with the program, despite difficulties with liquidity management experienced during and after Ramadan. Growth of currency in circulation surged from 8.5 percent during the first half of 2007/08 to 18 percent in October (or nearly 24 percent year-on-year). Continued exchange rate stability throughout this episode suggests that the surge in the money supply-related to an acceleration of government expenditure - was met with increased demand, reflecting a combination of Ramadan-related seasonality and steep increases in the prices of imported fuel and essential foodstuffs. In mid-October, DAB stepped up its foreign exchange interventions with a view to reducing the growth of currency in circulation to about 15 percent by December 2007, consistent with the program ceiling for the third quarter of $2007 / 08$. 
11. We met the structural benchmarks in the areas of central bank accounting and reporting. We have developed a monthly monetary survey in line with international standards (structural benchmark for end-July 2007) and are submitting it on a monthly basis to the IMF. We also have introduced the new accounting system at DAB and six regional hubs (structural benchmark for end-September 2007). The system still remains in a trial phase and the operations of the regional hubs are not yet automatically monitorable from headquarters.

12. Rapid growth in commercial bank activity prompted us to take action to strengthen bank supervision and the regulatory framework for the banking sector. We have completed a summary report on banks' compliance with prudential regulations based on a full round of on-site inspections, which revealed several weaknesses. We are now in the process of implementing targeted supervisory actions. Among other measures, we have instructed all banks to publish their audited financial statements. We have also enforced all licensing requirements for Bank Pashtany and Bank Millie, with the exception of the appointment of qualified managers, which would require lifting the ceilings on salary levels for state sector employees.

\section{External Sector and Debt Issues}

13. Developments in the first quarter, notably strong growth of recorded exports, and early indicators of donor activity, suggest that the external position of Afghanistan will strengthen further in $\mathbf{2 0 0 7 / 0 8}$. First quarter data show that recorded exports grew by 14 percent (in U.S. dollar terms) relative to the same quarter of 2006/07. We expect this trend to continue throughout the remainder of 2007/08 and contribute to a drop in the trade deficit (by $2 \frac{1}{2}$ percent of GDP). The latter is expected despite a significant pick up in dutyfree imports related to the increased external budget outlays, which are mainly securityrelated and are fully-funded by donors. As a result, we expect the current account deficit (including grants) to drop from 6.3 percent of GDP in 2006/07 to 1.4 percent of GDP in 2007/08. Foreign direct investment, debt relief from bilateral creditors, and interim assistance under the Heavily Indebted Poor Countries (HIPC) Initiative will contribute to the strengthening of our external position.

14. We have improved the collection of balance of payments data, although important shortcomings still need to be addressed. We have made significant progress in identifying data sources and strengthening data reporting by enhancing cooperation between the relevant government agencies and DAB. Although we have strengthened our expertise in the compilation of the balance of payments, further efforts are needed, including with technical assistance from the IMF.

15. We have continued our efforts to regularize relations with our creditors, after having reached the decision point under the HIPC Initiative in July 2007. In August 2007, we signed a bilateral agreement with Russia, and thus finalized the process of regularizing our debts with Paris Club creditors under the July 2006 Paris Club agreement. The agreement with Russia provides for a reduction of Russia's claims on Afghanistan by more than 90 percent, amounting to a reduction of our external debt by nearly 90 percent. During the 
IMF and World Bank annual meetings in October 2007, we also approached representatives from Bulgaria and the Kuwait Fund for International Development in an attempt to regularize our debts to these creditors.

\section{E. Other Structural Reforms}

\section{We have made some progress in divesting SOEs and restructuring the} state-owned banks. Of the 24 SOEs that were scheduled to be auctioned, 11 have already been sold. We have also lowered the price of six SOEs in order to auction them successfully. In addition, the Cabinet has approved the privatization of 15 other SOEs. In the absence of a comprehensive restructuring/divestment plan for SOEs and other commercial activities of the state that are not covered by the Tassady Law, we have resisted pressures to provide budgetary support to these entities, particularly the national airline Ariana. In the financial sector, Bank Millie, following the completion of its external audit, has taken a number of steps to restructure and improve its financial status. Completion of the audit of Bank Pashtany has been delayed, but its restructuring plan was approved by the Cabinet in August 2007. The client accounts of the Export Promotion Bank have been transferred to Bank Pashtany and the merger of the two banks is expected to be completed by March 31, 2008. To preserve the value of state-owned banks, we continue to prohibit lending from these banks to enterprises in need of restructuring (continuous structural performance criterion).

\section{Progress in reforming the legislative framework for the business environment} has been slow, in part due to the lengthy review process at the Ministry of Justice. The submission to parliament of laws on partnership and corporations, secure transactions, and negotiable instruments is still pending. We are concerned that further delays in the introduction of these laws are likely to impact adversely on private sector investment and the orderly development of the financial sector.

\section{F. Preparations for the ANDS}

18. We have made substantial progress towards the preparation of the ANDS-our PRSP — with a view to submitting it to the Boards of the IMF and World Bank by end-March 2008. Consultations in all 34 provinces have been completed and have resulted in provincial development plans (PDPs) for each province. We have also completed a first draft of all the sectoral strategy papers, which have been circulated to civil society and our development partners for comments. The PDPs and the sectoral strategies will be used to ensure that the ANDS includes targeted policy measures that reflect the development needs of each province and each sector, and measures to not only increase investment and growth, but also to reduce poverty. With the completion of the update of the 2005 National Risk and Vulnerability Assessment (NRVA) earlier this year, and the ongoing work on the 2007 NRVA, we have also improved our capacity to track the impact of government expenditure on poverty reduction. We have consulted with donors on their likely contributions to the core and external budget over the next five years. We are in the process of preparing proposals on broad sectoral priorities, and will engage government entities and the international community to reach agreement on the ANDS sectoral expenditure envelopes. 


\section{The Program FOR THE REMAINDER OF 2007/08 AND FOR 2008/09}

\section{A. Macroeconomic Objectives}

19. The near-term macroeconomic outlook remains positive, but inflationary pressures are expected to subside only gradually. A record harvest and strong growth in construction and government and business services suggest that the expectation of double-digit GDP growth in 2007/08 will be fulfilled. In 2008/09, growth in agriculture is expected to return to the predrought trend, but overall GDP growth is projected at about $9 \frac{1}{2}$ percent owing to the strengthened fiscal impulse from donor contributions in support of the ANDS. Given the anticipated trends in international commodity prices, inflation is expected to drop below 10 percent in 2008/09, assuming that prudent fiscal and monetary policies will be successful in containing the second-order effects of the exogenous price increases.

20. Economic growth over the medium term will depend critically on curbing corruption, overcoming infrastructure bottlenecks, and deepening structural reforms in support of private entrepreneurship. The projected combined donor-financed investment and domestic investment will decrease from above 40 percent of GDP in 2007/08 to about 30 percent of GDP in 2011/12, assuming that private investment would replace a portion of the declining public investment component to the tune of 1-2 percent of GDP per year. Under conservative assumptions with regard to investment efficiency reflecting Afghanistan's difficult natural conditions, absorption capacity limits, and inevitably high security costs, these levels of investment would be consistent with annual GDP growth rates ranging from 9 percent in 2008/09 to 7 percent in 2012/13. Higher growth rates could be expected if structural reforms accelerate, the quality of public expenditure improves, and public investment enhances key infrastructure, notably transport and electricity.

\section{B. Fiscal Policy}

21. We have undertaken measures to ensure that the good revenue performance will continue throughout the remainder of 2007/08. Revenue is projected to reach Af 35.7 billion ( 8.2 percent of GDP) in 2007/08. This is in line with the original program and goes beyond our objective of collecting revenue equivalent to 8 percent of GDP by 2010/11, as set out in the Afghanistan Compact agreed between the government and donors in London in 2006. (The downward revision of the GDP estimates implies that we achieved that objective last year). During the remainder of this fiscal year, we will endeavor to foster greater responsibility for revenue collection at the top levels of government and strive to safeguard the tax collection system against political interference. We will reach an agreement within the government on the taxation of airlines, including Ariana. We will also work with parliament to obtain timely approval of the government's proposed amendments to the tax legislation. A steering committee for tax and customs modernization was created to address these challenges - we will use this committee as a forum for advancing sustainable revenue reforms.

22. In October 2007, we conducted a limited midyear review of the budget for $\mathbf{2 0 0 7 / 0 8}$, in line with the understandings reached at the time of the second program 
review. Both operating expenditure and grants to the operating budget (on a cash basis) have been reduced by Af 1.5 billion relative to the original program to account for the receipt of fuel-in-kind from our international partners (published documents show expenditure of Af 54.8 billion). As a result, operating expenditure through end-2007/08 is now projected at Af 53.3 billion (12.2 percent of GDP). Within this amount, we have increased security expenditure by 0.9 percent of GDP by identifying additional donor contributions, as provided for under the program adjustor, and by reallocating funds from other items, such as the wage bill increment related to the Pay and Grade reform (postponed until the next fiscal year). As an increased envelope for security spending has now been built into the revised program baseline, the program adjustor for additional security expenditure is no longer necessary. We deem the new agreed envelope for security spending sufficient, but will consult with IMF staff should unexpected security-related pressures arise. To reflect the carryover of approved projects from last year, we have revised the core development budget upward by about Af 10 billion, to Af 87 billion (19.9 percent of GDP). Nevertheless, in light of systematic underspending in previous years, for program purposes we are targeting an amount of Af 45.5 billion (10.4 percent of GDP), only Af 1.4 billion higher than in the original program for $2007 / 08$. We also used the midyear budget review to settle payment arrears (to private contractors) that had accrued owing to weak financial management in several line ministries.

Adjustments to the 2006/07 Core Operating Budget in the Midyear Review

\begin{tabular}{|c|c|c|}
\hline & $\begin{array}{c}\text { Af } \\
\text { billion }\end{array}$ & $\begin{array}{c}\text { Percent } \\
\text { GDP }\end{array}$ \\
\hline Approved budget (excluding security adjuster) & 49.8 & 11.4 \\
\hline Additions: & 5.1 & 1.2 \\
\hline Security & 3.7 & 0.9 \\
\hline Governance \& Rule of Law & 1.0 & 0.2 \\
\hline Other & 0.3 & 0.1 \\
\hline Savings: & -1.5 & -0.4 \\
\hline Pay and Grade Reform & -0.5 & -0.1 \\
\hline Education & -0.9 & -0.2 \\
\hline Other & -0.1 & -0.0 \\
\hline Budget after midyear review & 53.3 & 12.2 \\
\hline Difference & -3.5 & -0.8 \\
\hline Use of agreed security adjuster 1 / & -2.3 & -0.5 \\
\hline Cash additions to core operating budget & -1.2 & -0.3 \\
\hline
\end{tabular}

1/ Security adjuster of Af 3.8 billion less "in-kind" contribution of Af 1.5 billion. 
23. Expenditure management efforts during the remainder of $2007 / 08$ will focus on regularizing the relations between the budget and public enterprises. To that end, we will initiate a review of the fiscal relations between the government and key SOEs (e.g., Afghan Telecom, Ariana, DABM - the electricity provider, FLGE - the petroleum trading SOE, and mining SOEs), in advance of the 2008/09 budget. The review will cover the period from 2005/06 onward and will focus on: (i) payment of bills and service charges by the line ministries; (ii) payment of taxes by SOEs; (iii) transfers of SOEs' profits to the Treasury account; and (iv) closure of unauthorized bank accounts. These measures should reduce the pressure to subsidize SOEs. Nevertheless, to obtain settlement of unpaid government bills, SOEs will need to present audited financial statements for the period of claims. We will also conclude, with assistance from the World Bank, an analysis of fiscal sustainability in the security sector.

\section{We will seek to reduce our operating budget deficit excluding grants from} 4.0 percent of GDP in 2007/08 to 3.6 percent in 2008/09. This is consistent with our medium-term fiscal objective of covering operating expenses with domestic revenue-a target that we expect to achieve by 2012/13. We are targeting domestic revenues of Af 44.5 billion (8.5 percent of GDP) for 2008/09. At the same time, operating expenditure in 2008/09 will be capped at Af 63.4 billion (12.1 percent of GDP) - this will allow us to accommodate recent decisions to increase the size of both the army and the police, accompanied by a Pay and Rank Reform in these sectors, and will provide for Af 2.8 billion in fuel subsidies for Da Afghanistan Breshna Moassesa (DABM). The ceiling on operating expenditures reflects a prudent approach to the wage bill, which seeks to encourage faster progress in the civilian Pay and Grade Reform. To that end, pay increases outside the reform process will be contained below inflation. Consistent with the PRGF program and the baseline scenario in the ANDS, core budget development expenditure is projected at Af 56.9 billion (10.9 percent of GDP) in 2008/09, representing a 25 percent increase in nominal terms over the expected outturn this year.

25. Revenue policy in $\mathbf{2 0 0 8 / 0 9}$ will focus on implementing measures to secure the success of major tax reforms slated for 2009/10. In this two-step process, we target a revenue increase of only 0.3 percent of GDP in 2008/09, to be followed by a further increase of 0.6 percent of GDP in 2009/10, which would bring the revenue-to-GDP ratio to 9.1 percent. In 2008/09, while maintaining the necessary collection efforts to achieve the annual revenue target, we will place greater emphasis on (i) consolidating the pertinent legislation; (ii) capacity building; and (iii) expanding administrative reforms. The legislative agenda, part of which has already been submitted to parliament, includes: (i) the elimination of nuisance taxes; (ii) reforms to income taxation; and (iii) measures toward transforming the BRT into a broad-based consumption tax, such as the imposition of a BRT on imports (to become effective in 2009/10 — structural benchmark for March 2009) and exempting financial services from the BRT. Once approved by parliament, we will promptly announce these measures to the public. We will also conduct an information campaign within the trader community prior to withdrawing the concessions on filing and paying taxes (structural benchmark for March 2009) that had been granted to traders. In the meantime, we will focus on key administrative reforms to maximize the benefits of the planned tax policy measures. First and foremost, we will ensure adequate resourcing of the Revenue and Customs 
Departments, focusing on the retention of qualified staff and the needs of the major provincial tax offices. Based on this, we will roll out the operations of the LTO and MTO to five key provinces. We will also refine the crediting mechanism currently used for the income tax with a view to applying a similar mechanism to the BRT that will be collected on imports, thus alleviating partially the cascading of this tax. We will also continue to expand the collection net to capture high value tax payers, including airlines, security companies, and landlords.

26. On the expenditure side, we will focus on fiscal discipline, improving the quality of public expenditure, and aligning it with the ANDS' priorities. Several reforms are critical in this regard:

- On budget formulation, we will expand the program budget pilots to seven ministries and ensure that the program structure is aligned with the ANDS sector strategies. This reform will not only help integrate budget formulation in line ministries, but will also contribute to aggregate discipline as decision makers are presented with information that will facilitate prioritization (March 2008).

- We will work with our development partners to strengthen financial management in the line ministries. In particular, we will ensure that the government priorities, as defined in the budget, are implemented and will seek to eliminate the build up of arrears in line ministries (throughout 2008/09).

- $\quad$ The Treasury Department will restructure operations in three provincial Mustofiats by using the Afghanistan Financial Management Information System (AFMIS) to process transactions of these Mustofiats and by hiring the staff needed to execute treasury functions on a PRR (priority restructuring and reform) basis (March 2008).

- $\quad$ The MOF will implement a new procedure to integrate and restructure allotment management arrangements based on a commitment management system and financial plans from all budgetary units (March 2008).

- $\quad$ To improve payroll management, we will adopt, in consultation with line ministries and donors, an action plan for implementing a computerized payroll system that will allow the MOF to track payroll payments for all government employees (January 2008).

- We will take decisive actions to contain potential fiscal drains resulting from lack of financial discipline in the public enterprises, particularly, DABM. To this effect, we will follow through on our commitment to establish a comprehensive agreement with the DABM on a medium-term plan to reduce subsidies. For 2008/09 - as we do not envisage any additional sources of electricity coming on line-we will reach an interim agreement with DABM (structural benchmark for March 2008) on quarterly reform benchmarks to be met in exchange for subsidy disbursements (see Technical Memorandum of Understanding (TMU $\mid 2$ ). Key conditions will include submitting 
financial statements for 2006/07-2007/08 (by June 2008), achieving measurable improvements in collection performance, and cutting physical theft of electricity. By September 2008, in collaboration with DABM, we will prepare a draft medium-term plan to gradually reduce and eventually eliminate the energy subsidy. The viability of the plan will be predicated on: (i) DABM's restructuring; (ii) optimal use of existing and new electricity sources; (iii) tariff increases for premium power users; and (iv) scheduled load shedding for residential customers (as opposed to cutting supply to control costs, as is presently the case). Moreover, we will ensure that at no stage the increase in electricity supply leads to an increase in subsidies. We will finalize this plan and agree with DABM on the timetable for its implementation by December 2008 (structural benchmark).

- We will continue to monitor fiscal risks related to aid volatility and work with donors on refining our projections in this area.

- $\quad$ Implementation of the Pay and Grade reform will start before September 2008.

27. We will continue to strengthen the MTFF as a policy tool for the government. The MTFF will be the primary instrument for setting fiscal parameters for the annual budget process and the ANDS envelope, and for analyzing fiscal sustainability. To that end, we will determine, and subsequently update on an annual basis, the fiscal parameters for the ANDS macroframework. For the 2008/09 budget, the MTFF will: (i) set out our medium-term plan to eliminate the operating budget deficit before grants; establish indicative sectoral allocations for both the core and external budgets; and (ii) provide envelopes for key crosscutting areas, such as Pay and Grade Reform and maintenance costs associated with investment spending. The latter will build on our recent work with the World Bank and security partners to assess fiscal sustainability in the security sector. It will include concise descriptions of the policy actions necessary to meet fiscal objectives, on both the revenue and expenditure fronts. The improvements to the MTFF will be in line with the understandings underpinning the HIPC completion point triggers.

\section{Monetary and Exchange Rate Policies}

28. Monetary policy will seek to contain inflationary pressures. In this context, we consider the original currency in circulation ceiling for 2007/08 (consistent with a 19 percent growth in the demand for the Afghanis) appropriate, even though nominal GDP growth in $2007 / 08$ is likely to exceed this figure by about five percentage points. The major contribution to growth in 2007/08 comes from agriculture, which adds comparatively less than other sectors to the demand for domestic currency. The envisaged monetary tightening will limit the increase in the prices of nontradables, and will help contain inflation. In $2008 / 09$, we expect economic growth to be more broad-based and the demand for money to increase by about 20 percent, in line with the nominal GDP growth.

\section{Foreign exchange auctions will remain a primary instrument of monetary}

policy. DAB will make no commitment to purchase Afghanis at a pre-determined rate and thus uphold the managed float character of the exchange regime. Seasonally-adjusted quarterly currency-in-circulation targets (consistent with the program currency-in-circulation 
ceiling) will provide guidance for DAB's foreign exchange interventions, while the degree of flexibility will enable the DAB to smooth out short-term exchange rate fluctuations. DAB will ensure the observance of the " $T+2$ " rule for the settlement of the bids in foreign exchange auctions and impose adequate penalties on violators, including escalating fines and, ultimately, suspension of money changers licenses for multiple offenders.

30. DAB will improve the standing arrangements for the provision of cash (in Afghanis and in U.S. dollars). To this effect, DAB will satisfy the constitutional requirement of consulting with parliament on cash printing once a year when presenting its annual report, and will make advance arrangements for ensuring an adequate supply of Afghani notes during the year. The guidelines on importing and exporting U.S. currency will also be articulated clearly and incorporated in DAB's operating procedures. DAB will also improve liquidity forecasting - in cooperation with the MOF — in order to ensure a smooth implementation of monetary policy. In particular, DAB management will strengthen the internal consultation mechanism over liquidity forecasts and intervention policy by endowing the Monetary Policy Department with greater ownership and accountability for its policy advice.

31. DAB will be expanding the volume of capital notes auctions with a focus on managing bank liquidity and developing a yield curve. Preparations for launching the secondary market in capital notes (CNs) will be finalized in February 2008. Subsequently, $\mathrm{DAB}$ will articulate the steps leading to the opening of the secondary market for CNs and promulgate the rules guiding secondary market transactions among the commercial banks. Meanwhile, DAB will increase the volume of auctions and strengthen the procedure for determining ex ante the amounts to be auctioned.

32. We continue to develop controls against money laundering and financing of terrorism (AML/CFT) in the banking and other sectors. We intend to have all the appropriate controls in place prior to the first AML/CFT evaluation of Afghanistan by the Asia Pacific Group on Money Laundering, which is expected to take place in the third quarter of 2008.

\section{Strengthening of DAB's Accounting and Reporting Framework}

\section{The introduction of the new accounting system at DAB forms the basis for} strengthening internal control and improving the quality of data available to inform policy decisions. Nevertheless, further steps are needed to make the new system fully operational. With assistance from the Middle East Technical Assistance Center (METAC), we will work toward finalizing this task and ensure that the new accounting system at the six regional hubs is fully integrated with that at DAB's headquarters and satisfies the standards required for central bank operations (structural benchmark for end-March 2008).

34. We will also take steps to strengthen the quality of the monthly reporting of DAB's operations. To this effect: (i) by December 20, 2007, we will take stock of discrepancies between the monthly reports based on the accounting records and the reports produced by the Monetary Policy Department for program monitoring and reporting;

(ii) subsequently, we will eliminate these discrepancies by correcting the errors in the source 
data; (iii) by the beginning of fiscal year 2008/09, and only if satisfactory reconciliation is achieved, we will use the data based on the accounting records for program monitoring and reporting monetary operations to the IMF.

35. Since July 2007 DAB has been producing monetary surveys of a better quality. In the period ahead, DAB will reconcile central bank and commercial banks reporting (based on a consistent Gregorian or Solar Calendar time-frame) and publish integrated monetary surveys using a consistent time-frame.

\section{E. Safeguards Assessment Issues}

36. We have renewed our commitment to improving DAB's operations and control framework by implementing the IMF's updated safeguards recommendations. To provide assurances regarding the level of DAB's reserve assets, we have requested our external auditors to conduct an independent verification of these assets and their availability as of September 22, 2007 (prior action). In addition, we will take steps to complete the annual audit of financial year 1385 (2006/07) by end-December 2007, and appoint an external auditor for financial year 1386 (2007/08) by end-December 2007 (prior action). We will also continue with the process of implementing the new accounting system and addressing audit observations for the financial year 1385 concerning weaknesses in controls, with priority given to the accounting and foreign reserves management areas.

\section{F. Bank Supervision and Financial Sector Policies}

\section{To safeguard the soundness of the banking sector, we will continue to} strengthen bank supervision and address banks' noncompliance with prudential regulations. Effective immediately, we will stop awarding licenses for opening new branches to banks exhibiting "well-defined weakness" (i.e., banks with Capital adequacy, Asset quality, Management, Earnings, and Liquidity (CAMEL) ratings of 4 and 5). Also, given the absence of appropriate risk management skills and the limited effective collateral, we will limit the credit growth of such banks to 5 percent per quarter beginning end-December 2007. This limitation will remain in effect for those banks whose CAMEL ratings continue to be assessed as 4 or 5 by DAB's banking supervision department. We will notify the banks by end-November 2007 of our decision. We will also revise the enforcement regulations to ensure that corrective actions are taken promptly, and will follow up on the banks' failure to comply with these actions. To that end, we will put in place automatic measures, including fines for each day of failing to comply with DAB's orders. We are in the process of developing an off-site supervision form detailing sectoral loan classification. As of December 2007, banks will be required to report their loans to DAB based on these new forms. To increase the transparency of the legal framework for commercial bank operations, we intend to consolidate all pertinent regulations in a handbook. 
38. We will seek to enhance coherence in the regulatory framework for the banking sector in close consultation with IMF staff. DAB's Supreme Council will repeal the decisions instituting the requirement to invest 80 percent of bank deposits in the domestic economy and raising the minimum capital requirement from US\$5 million to US\$20 million. DAB will issue circulars informing banks that these decisions have been repealed (structural benchmarks for end-March 2008). After consultation with IMF staff, we believe that the minimum capital requirement for commercial banks should be raised to US\$10 million. The new requirement will be applicable immediately for new banks seeking licenses, while incumbent banks will be given 5 years to comply. In relaxing our position on minimum capital requirements, we are recognizing the need to ensure that small but well-run banks continue to operate.

39. We will also modify two tax policy provisions applicable to the banking sector. Taxation of income from bank deposits will be applied uniformly to all commercial banks, including state-owned and private banks, and the provisions calling for the withholding of taxes on interbank lending will be withdrawn. Both actions will be taken by end-2007/08.

\section{G. External Sector Policies}

40. We are committed to a trade regime that minimizes distortions and does not discriminate across importers. Consistent with this objective, the decree (No. 5016) allowing selected producers to import raw materials at a 1 percent tariff rate will be repealed by December 31, 2007 (prior action). The goods eligible for the 1 percent rate will be incorporated in the tariff schedule at rate(s) to be decided, with due consideration for government revenue. Moreover, we intend to repeal, by end-March 2009, the decree (No. 96) that raised the tariff rate on soft drinks from 20 to 40 percent, and reduce the applicable tariff rate to 20 percent. Fund staff and the authorities have reached an understanding that this measure will be a structural performance criterion for a later review. Furthermore, we will refrain from introducing any discriminatory trade policy measures and reclassifying goods into higher tariff bands, and will unwind previous tariff increases once the revenue situation permits. We also intend to limit changes to the tariff schedule by (i) acting in accordance with paragraph 23.2 of the customs law, which states that "the customs tariff shall be approved by the Minister of Finance upon the recommendation of the General Director of Customs;" and (ii) avoiding changes to the tariff schedule outside the annual budget process. Finally, we are committed to an even-handed application of the tariff schedule and will promptly redress any irregularities in this regard, including in the case of gasoline.

41. We are also committed to maintaining a foreign exchange system free of restrictions. In this regard, we look forward to receiving technical assistance from the Fund to assist us in assessing the adequacy of our legal framework and in formalizing a restrictions-free exchange system consistent with our aim of accepting the obligations under the Article VIII, Sections 2, 3, 4 of the Fund's Article's of Agreement.

42. We will continue to make efforts to regularize relations with all our creditors while pursuing a prudent debt management strategy consistent with achieving external debt sustainability. In this regard, we will work toward reaching agreements with our 
non-Paris Club bilateral and commercial creditors on terms at least comparable with those received from Paris Club creditors, and will redouble our efforts to complete a debt relief agreement with the OPEC Fund for International Development (OFID). Moreover, we will continue to rely primarily on grants and highly concessional loans to meet our financing needs. The government and DAB will not contract or guarantee any nonconcessional external debt (continuous performance criterion).

\section{H. Petroleum Sector}

43. We remain committed to a transparent and competitive petroleum sector, with the private sector playing the dominant role. The recent decision of the Fuel and Liquid Gas Enterprise (FLGE) to import fuel for state-owned retail pump stations was necessary because of temporary shortages, which led to sharp increases in retail prices. Nonetheless, the government's intention, as highlighted in the Afghanistan Compact, is to withdraw from the oil sector and privatize the FLGE by March 2009. To this end, we intend to reduce gradually the FLGE's imports of petroleum products and, ultimately, limit its role to providing services to the private sector. We will ensure that fees collected for the FLGE's services will not be used to subsidize the fuel sold by FLGE, including at state-owned retail pump stations. To improve transparency in the sector, we also plan to publish a schedule of fees for FLGE's services (end-February 2008 structural benchmark). We remain mindful of the need to protect the consumer by maintaining competitive market conditions, and are in the process of formulating an anti-trust law for that purpose. To improve transparency and prepare for the privatization of the FLGE, we have commissioned an external audit of its accounts for 2007/08, which would be completed by November 2008. Upon completion of the audit, we will promptly publish the audit report (structural benchmark).

\section{Other Structural Reforms}

44. We will redouble our efforts to finalize the strategic plan for the non-Tassady public enterprises and government entities engaged in commercial activities. We will prepare a strategic plan for non-Tassady enterprises for Cabinet adoption by March 31, 2008 (structural benchmark). Regarding Ariana, we will not: (i) assume payment obligations for liabilities contracted without government guarantee; (ii) provide government guarantees for new obligations; or (iii) approve lending to Ariana by state-owned banks.

45. We will follow through on our plans to restructure the state-owned banks (Pashtany and Millie) and will establish a timetable for finalizing the liquidation of delicensed state-owned banks. We are also committed to resolving the outstanding issues raised in the context of the external audit of Bank Pashtany, with a view to enabling the completion of the audit report by December 20, 2007.

\section{J. ANDS and HIPC-Related Issues}

46. Prioritization and realistic costing of sectoral strategies will be key to the quality of the ANDS. In order to complete the ANDS on schedule, we are initially costing three sectoral strategies (education, health and roads), which will be included in the 2008/09 budget. The remaining sectoral strategies will be costed in time for the first ANDS annual 
progress report, which we intend to submit to the Boards of the IMF and the World Bank in early- to mid-2009. As the financing needs implied by the sectoral strategies and PDPs are expected to exceed available resources, we will use the MTFF to balance the needs of different sectors and provinces with fiscal prudence, and to spread the implementation of the ANDS over a realistic timeline.

\section{Progress continues towards meeting our HIPC completion point triggers.}

Regarding the HIPC completion point triggers within the IMF's areas of responsibility, we aim to strengthen our debt management capacity by publishing quarterly external debt reports, starting with the report for the first quarter of 2008/09 within three months of the end of the quarter, and by implementing a database system on external debt by end-September 2008. The 2008/09 budget formulation process will seek to satisfy the trigger on alignment of public spending priorities, and the MTFF published alongside the budget will be in line with the criteria set out in the HIPC trigger. We are modifying the Treasury's Chart of Accounts to enable the tracking of poverty reducing expenditures during 2008/09. Annual audits of the core budget's financial statements will proceed in line with the requirements of the HIPC trigger.

\section{K. Statistical Issues}

48. Several initiatives are under way to improve Afghanistan's statistics in the key sectors for economic policy and the ANDS. In August 2007, we began the 2007 NRVA, which extends the consumption module of the 2005 NRVA to a larger number of nonfood items. We have also made preparations for launching the Integrated Business Enterprise Survey in February 2008. The findings of these surveys will help upgrade the social database and serve as a basis for strengthening the national accounts.

\section{We plan to intensify our efforts to build the capacity of the Central Statistics}

Office (CSO), including by appointing the head of CSO, increasing training, providing adequate resources through securing funding from donors, and restructuring its operations. In coordination with the donor community, CSO intends to develop a detailed blueprint to address the weaknesses in the national income accounts database. Finally, we plan to launch the national household census in August 2008.

50. We will continue to work toward compiling a balance of payments for $2007 / 08$. To that end, DAB and AISA, in consultation with the STA expert from the IMF will jointly launch by year's end a FDI survey for 2007/08 to a sample of companies, with a view to completing it before the end of the first quarter of 2008/09. Moreover, CSO will improve the quality of merchandise trade data, including duty-free imports, and the timeliness of their reporting. It will also coordinate with the MOF to improve the consistency between the CSO trade data and those reported by the Customs Department.

\section{Program Monitoring}

51. The program will be monitored through quantitative performance criteria for March 2008 and indicative targets for December 2007, June 2008, and September 2008. The fourth review under the arrangement is scheduled to be completed by June 2008 and will be 
conditional upon compliance with the quantitative performance criteria and structural conditionality through March 2008. The updated TMU (attached) specifies the details of program monitoring, including definitions of performance criteria and adjusters, and data provision requirements.

52. During the program period, Afghanistan will not impose or intensify restrictions on the making of payments and transfers for current international transactions, or introduce or modify multiple currency practices, or conclude bilateral payments agreements inconsistent with Article VIII, or impose or intensify import restrictions for balance of payments purposes. 
Table 1. Islamic Republic of Afghanistan: Performance Criteria and Indicative Targets for 2007/08-mid-2008/09 1

(For 2007/08, cumulative changes from March 20, 2007 and for 2008/09, cumulative changes from March 19, 2008; unless otherwise indicated)

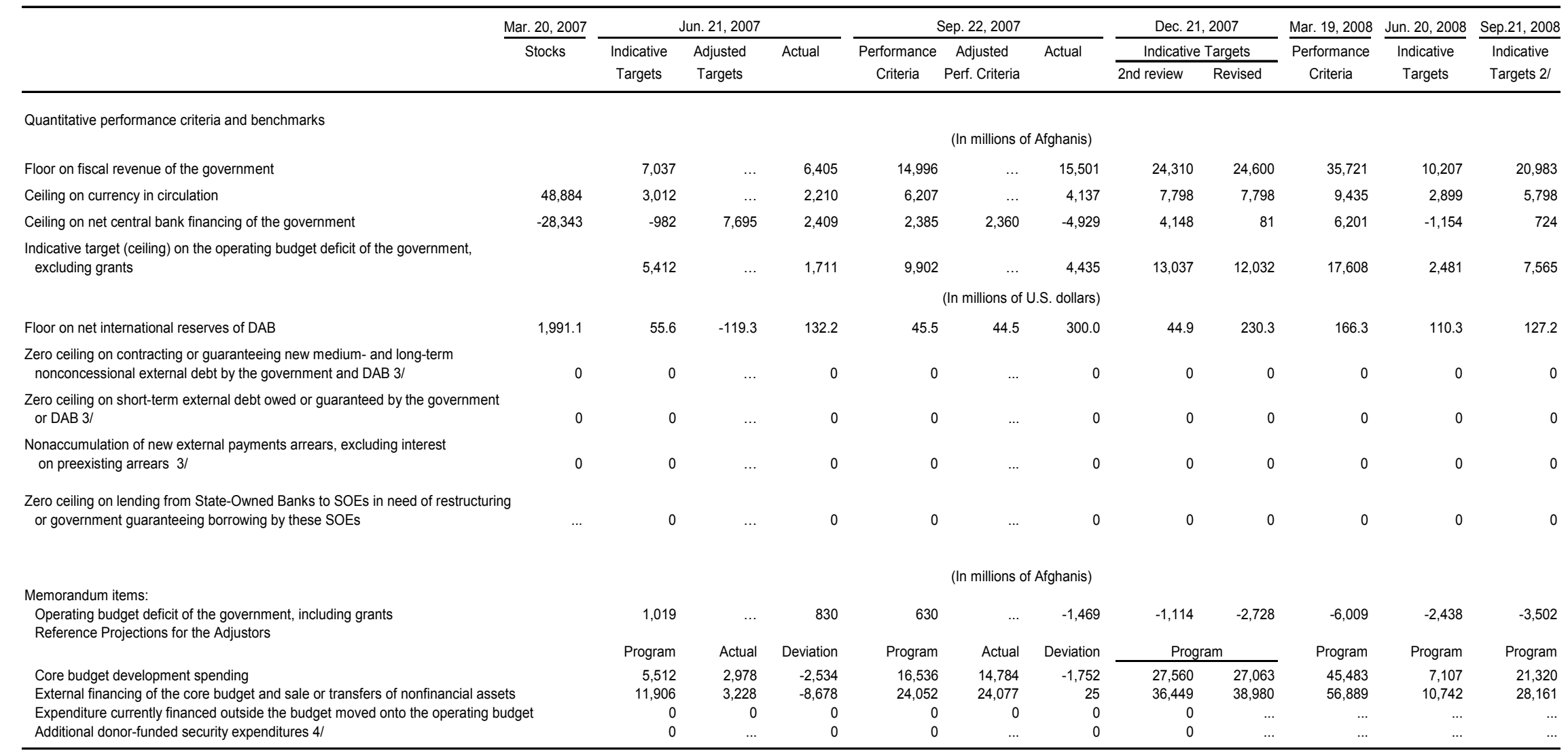

Sources: Afghan authorities; and Fund staff estimates and projections.

1/ The performance criteria and indicative targets envisaged under the program, and their adjustors, are defined in the Technical Memorandum of Understanding.

2/ Will be converted into performance criteria at the fourth PRGF review.

3/ These performance criteria apply on a continuous basis.

4/ The program provided for additional Af 3,800 million in the first half of $2007 / 08$ in donor-supported security spending. At the midyear review, the additional security spending was incorporated in the budget. 


\section{Table 2. Islamic Republic of Afghanistan: Structural Performance Criteria and Structural Benchmarks, July 2007-March 2009}

\section{Third Review Under the PRGF Arrangement}

\section{Prior Actions}

DAB's external auditor, KPMG Afghanistan, should complete a special audit of the central bank's reserve assets reported to the IMF as of September 22, 2007. The audit should be conducted in accordance with International Standards on Auditing. 1/

DAB should appoint a reputable international audit firm to audit the bank's annual financial statements for financial year 1386 (2007/2008) in accordance with International Standards on Auditing.

Eliminate the discriminatory application of the 1 percent tariff rate on imports of raw materials and intermediate goods by repealing the Decree Nr. 5016, effective December 31, 2007.

\section{Structural Performance Criteria}

Submit to parliament the core budget's audited financial statement for 2006/07.

\section{Structural Benchmarks}

Develop a monthly monetary survey in line with international standards.

Clarify the tax policy framework and system, including the difference between the BRT and income taxes.

Prepare (and submit to the Cabinet) a restructuring plan for Bank

Pashtany based on the bank's audited financial statement.

Adopt a comprehensive restructuring/divestment plan for the public entities and government agencies engaged in commercial activities but not covered by the SOEs law.

Expand the automated integrated accounting system to DAB's six regional hubs.

Issue regulations on credit-granting standards and credit monitoring process.

Issue regulations on setting limits on sectoral loan concentration.

\section{Fourth Review Under the PRGF Arrangement}

\section{Structural Benchmarks}

Submit core budget to parliament according to the PFEM Law and accompanied by a MTFF.

Publish a schedule of the fees charged by the FLGE for its services.

MOF will conclude an agreement with the DABM on quarterly reform benchmarks to be met by DABM throughout 2008/09 in exchange for the subsidy disbursements.

\section{Target Dates}

Five days before Board meeting

December 31, 2007

December 31, 2007

Target Dates

September 21, 2007

Target Dates

July 31,2007

July 31, 2007

August 31, 2007

September 30, 2007

September 30, 2007

November 30, 2007

November 30, 2007

Target Dates

February 3, 2008

February 29, 2008

March 21, 2008
Status

Implemented Staff received the audit report on January 9 , 2008

Implemented

Implemented

\section{Status}

Not implemented 2/

Status

Implemented

Implemented

Partially implemented 3/

Not implemented

Implemented

Not implemented

Not implemented 


\section{Table 2. Islamic Republic of Afghanistan: Structural Performance Criteria and Structural Benchmarks, July 2007-March 2009 (Concluded)}

\section{Structural Benchmarks}

Adopt a comprehensive restructuring/divestment plan for the public entities and government agencies engaged in commercial activities but not covered by the SOEs law.

DAB will issue a circular informing banks that the requirement to invest 80 percent of bank deposits in domestic economy has been repealed.

Ensure that the accounting system at DAB's six regional hubs is automatically monitorable from DAB's headquarters.

Reconcile DAB's accounting records and the monthly reports on DAB's operations for $2007 / 08$ prepared by DAB's Monetary Policy

Department.

\section{Future Reviews Under the PRGF Arrangement}

\section{Structural Benchmarks}

DAB will produce the Monetary Survey for $2007 / 08$ using a consistent time frame (Solar or Gregorian) for the entire banking system.

Submit to parliament the core budget's audited financial statement for 2007/08. 4/

Publish external audit report of FLGE.

MOF will conclude a comprehensive agreement with the DABM on a medium-term plan to reduce subsidies.

Withdraw trader concessions on filing and paying taxes.

Start collecting BRT on imports.

Reduce to 20 percent the 40 percent tariff rate on soft drinks established by Presidential Decree Nr. 96. 4/
Target Dates

Status

March 31, 2008

March 31, 2008

March 31, 2008

April 20, 2008

Target Dates

Status

June 30, 2008

September 21, 2008

November 30, 2008

December 31, 2008

March 21, 2009

March 21, 2009

March 31, 2009

1/ Terms of Reference for special audit have been provided by IMF staff to the authorities.

2/ The authorities made the submission on September 22, 2007 (the last day of the sixth month of the Afghan calendar), and, thus, complied with the PFEM Law. Staff supports the authorities request for a waiver of nonobservance.

3/ The restructuring plan for Pashtany bank has been sent to Cabinet, but it is not based on the audit report because the audit took longer than expected.

4/ Fund staff and the authorities have reached an understanding that this measure will be a structural performance criterion for a later review. 


\section{ATTACHMENT III: TeCHNICAL MEMORANDUM OF UNDERSTANDING}

1. This memorandum sets out the understandings between the Afghan authorities and Fund staff relating to the monitoring of the Poverty Reduction and Growth Facility (PRGF)-supported program approved by the IMF Executive Board on June 26, 2006. It defines the structural performance criterion and benchmarks (Section I), as well as the principal concepts and financial variables, including the quantitative performance criteria and indicators (Section II). It also sets out data reporting requirements (Section III).

\section{Structural Performance Criterion and Benchmarks}

2. Prior actions for the third review and structural performance criterion and benchmarks for the fourth, fifth, and sixth reviews are specified in Table 2 of the Memorandum of Economic and Financial Policies (MEFP) are defined as follows:

\section{A. Third Review Under the PRGF Arrangement}

\section{Prior actions}

- DAB's external auditor, KPMG Afghanistan, should complete a special audit of the central bank's reserve assets reported to the IMF as of September 22, 2007. The audit should be conducted in accordance with International Standards on Auditing and the terms of reference provided by IMF staff to the authorities.

- DAB should appoint a reputable international audit firm to audit the bank's annual financial statements for financial year $1386(2007 / 2008)$ in accordance with International Standards on Auditing.

- Eliminate the discriminatory application of the 1 percent tariff rate on imports on raw materials and intermediate goods by repealing the Decree Nr. 5016, effective December 31, 2007.

\section{B. Fourth Review Under the PRGF Arrangement}

\section{Structural benchmarks}

- Submit core budget to parliament according to the PFEM Law and accompanied by a MTFF.

- Publish a schedule of the fees charged by the FLGE for its services. This schedule shall be published on the external website of the Ministry of Commerce and Industry. It shall include details of the fees payable for the use of the FLGE's storage, laboratory and transport facilities, as well as any fees charged for installing and maintaining fuel pump station equipment. 
- MOF will conclude an agreement with the DABM on quarterly reform benchmarks to be met by DABM throughout 2008/09 in exchange for the subsidy disbursements. The benchmarks will include (i) submission by DABM of audited financial statements for 2006/07-2007/08 by June 2008; (ii) targets for improvements in tariff collection (including from government entities);

(iii) regularization of relationship with the budget (correct and transparent recording of tax payments and receipts of subsidies and tariffs); and (iv) targets for reducing physical theft of electricity.

- Adopt a comprehensive restructuring/divestment plan for public entities and government agencies engaged in commercial activities but not covered by the SOEs law. This restructuring/divestment plan will reflect the necessary steps and tasks entailed by the restructuring/divestment process and a schedule for their implementation. The plan shall be adopted by the Cabinet.

- DAB will issue a circular informing banks that the requirement to invest 80 percent of bank deposits in domestic economy has been repealed.

- Ensure that the accounting system at DAB's six regional hubs is automatically monitorable from DAB's headquarters.

- Reconcile DAB's accounting records and the monthly reports on DAB's operations for 2007/08 prepared by DAB's Monetary Policy Department. The reconciliation will be conducted in accordance with the procedures agreed upon with the IMF.

\section{Future Reviews Under the PRGF Arrangement}

\section{Structural performance criteria}

- Submit to parliament the core budget's audited financial statements for 2007/08. The PFEM law requires the government to submit and independent audit report of the core budget financial statements to parliament at least six months before the end of the fiscal year. the report will be prepared by the Control and Audit Office in accordance with international accounting practices.

- $\quad$ Reduce to 20 percent the 40 percent tariff rate on soft drinks established by Presidential Decree Nr. 96. 


\section{Structural benchmarks}

- $\quad$ DAB will produce and publish the Monetary Survey for 2007/08 using a consistent time frame (Solar or Gregorian calendar) for the entire banking system.

- Publish external audit report of FLGE. The audit shall cover FLGE's financial statements for 2007/08 and shall be conducted in accordance with international accounting principles. In addition, the audit shall cover FLGE's headcount and wage bill, and will include a review of FLGE's commercial dealings with the government and other state-owned enterprises. The audit report shall be published on the Ministry of Commerce and Industry's external website.

- $\quad$ MOF will conclude a comprehensive agreement with the DABM on a medium-term plan to reduce subsidies. The plan will be implemented by December 2008 and shall include steps to reduce and gradually eliminate the fuel subsidy. Key components of the plan would include: (i) measurable benchmarks on DABM's restructuring process.; (ii) an agreement on the optimal use of existing and new generation capacity; (iii) tariff increases for premium power users as the electricity supply improves; (iv) targets for improved collection from government ministries and agencies (could include centralized debits from ministry and agency budget allocations if arrears are built up); (v) a schedule of tax payments to the Ministry of Finance; and (vi) a plan for scheduled load shedding for residential customers.

- Withdraw trader concessions on filing and paying taxes. By March 21, 2009, the current agreement, whereby traders do not have to file any tax returns if they have paid the 2 percent fixed tax on imports in lieu of income tax, will cease. Registration with the tax authorities for BRT and income tax will be determined by the relevant thresholds as set out in legislation.

- $\quad$ Start collecting BRT on imports. By March 21, 2009, the Government will start collecting the BRT on imports, in addition to the existing 2 percent advance payment of income tax.

\section{Quantitative Performance Criteria And Indicative Targets}

3. The quantitative performance criteria and indicative targets specified in Table 1 of the MEFP are:

- a floor on fiscal revenue of the central government;

- a ceiling on currency in circulation;

- $\quad$ a ceiling on the net central bank financing (NCBF) of the central government; 
- $\quad$ a floor on net international reserves (NIR);

- $\quad$ a zero ceiling on contracting and/or guaranteeing new medium- and long-term nonconcessional external debt by the government and DAB (continuous);

- $\quad$ a zero ceiling on short-term external debt owed or guaranteed by the government or DAB (continuous);

- a zero ceiling on the accumulation of external payment arrears, excluding interest on preexisting arrears (continuous);

- $\quad$ a zero ceiling on lending from state-owned banks to, or government guaranteed borrowing by, state-owned enterprises in need of restructuring (continuous); and

- $\quad$ a ceiling for the operating budget deficit of the central government, excluding grants (indicative target).

\section{A. Program Exchange Rates and Gold Valuation}

4. Program exchange rates will be used for purposes of monitoring the quantitative targets under the program. All foreign assets and liabilities denominated in U.S. dollars will be converted into Afghanis using a program exchange rate of 50.08 Afghanis per U.S. dollar, which corresponds to the average of the Af/US\$ buy and sell cash rates, as reported by DAB as of March 19, 2007. For assets and liabilities denominated in SDRs and in foreign currencies other than the U.S. dollar, they will be converted into U.S. dollars at their respective exchange rates prevailing as of March 19, 2007, as reported in the following table. Gold holdings will be valued at US\$653.47 per ounce, the price as of March 19, 2007.

\begin{tabular}{|l|l|}
\hline Exchange Rate & Program Rate \\
\hline U.S. dollar/Canadian dollar & 0.850770 \\
\hline U.S. dollar/U.A.E. dirham & 0.272330 \\
\hline U.S. dollar/Egyptian pound & 0.175290 \\
\hline U.S. dollar/Euro & 1.330750 \\
\hline U.S. dollar/Hong Kong dollar & 0.128005 \\
\hline U.S. dollar/Indian rupee & 0.022721 \\
\hline U.S. dollar/Pakistani rupee & 0.016468 \\
\hline U.S. dollar/Polish zloty & 0.343796 \\
\hline U.S. dollar/Iranian rial & 0.000108 \\
\hline U.S. dollar/Saudi rial & 0.266670 \\
\hline U.S. dollar/Russian ruble & 0.038400 \\
\hline U.S. dollar/Swiss franc & 0.825490 \\
\hline U.S. dollar/United Kingdom pound & 1.944950 \\
\hline U.S. dollar/SDR & 1.509310 \\
\hline
\end{tabular}




\section{B. Currency in Circulation}

5. Currency in circulation is defined as total currency issued by DAB. It excludes currency held in the presidential palace vault, in DAB main vault, and in the vaults of all DAB's provincial and district branches.

\section{Net Central Bank Financing of the Government}

6. NCBF of the government is defined as the difference between the central bank's claims on the government and the deposits of the government with DAB. These deposits include the deposits held at DAB headquarters, but exclude the deposits held at DAB's branches. ${ }^{1}$

\section{Net International Reserves}

7. Net international reserves (NIR) are defined as reserve assets minus reserve liabilities of DAB.

8. Reserve assets of DAB, as defined in the fifth edition of the balance of payments manual (BPM5), are claims on nonresidents denominated in foreign convertible currencies, that are controlled by $\mathrm{DAB}$, and are readily and unconditionally available for $\mathrm{DAB}$ to meet balance of payments financing needs, intervention in exchange markets, and other purposes. They include DAB holdings of monetary gold, SDRs, Afghanistan's reserve position in the IMF, foreign currency cash (including foreign exchange banknotes in the vaults of DAB, but excluding cash held in DAB's branches), and deposits abroad (including balances on accounts maintained with overseas correspondent banks). Excluded from reserve assets are any assets that are pledged, collateralized, or otherwise encumbered; ${ }^{2}$ claims on residents; precious metals other than monetary gold; assets in nonconvertible currencies; illiquid assets; and claims on foreign exchange arising from derivatives in foreign currencies vis-à-vis domestic currency (such as futures, forwards, swaps, and options).

9. Reserve liabilities are defined as short-term (original maturity) foreign exchange liabilities of DAB to nonresidents (held at DAB headquarters); all credit outstanding from the IMF; foreign currency reserves of commercial banks held at DAB headquarters; commitments to sell foreign exchange arising from derivatives (such as futures, forwards,

\footnotetext{
${ }^{1}$ This definition differs slightly from international standards owing to the unavailability of reliable and timely government deposit data from DAB's branches.

${ }^{2}$ In particular, assets that are counterpart of the government's foreign currency deposits that back letters of credit are excluded from the reserve assets. However, assets that are counterpart of other government deposits are included in the reserve assets.
} 
swaps, and options); and all arrears on principal or interest payments to commercial banks, suppliers, or official export credit agencies.

10. Reserve assets and reserve liabilities will both be expressed in U.S. dollars.

\section{E. Revenues of the Central Government}

11. Revenues of the central government are defined in line with the Government Financial Statistics Manual (GFSM 2001) on a cash accounting basis, excluding foreign grants. Revenue is an increase in net worth of the central government (including its units in the provinces and agencies) resulting from a transaction. Revenues of the central government include taxes and other compulsory transfers imposed by central government units, property income derived from the ownership of assets, sales of goods and services, social contributions, interest, fines, penalties and forfeits and voluntary transfers received from nongovernment other than grants. The definition for program monitoring excludes grants and other noncompulsory contributions received from foreign governments and international organizations; such transfers between central government units would be eliminated in the consolidation of the fiscal reports and not recorded as revenue. Receipts collected by central government on behalf of noncentral government units should not be counted as revenue (e.g., Red Crescent fees). Receipts from the sale of nonfinancial assets, such as privatization, and transactions in financial assets and liabilities, such as borrowing but excepting interest payments, are also excluded from the definition of revenue.

12. Revenues should be recognized on a cash basis and flows should be recorded when cash is received. Exceptional advanced payments will be treated as if received on the normal due date. All revenue must be supported by the relevant documentation and revenue receivables, where a cash sum has been recorded but the revenue item has not yet been accounted for, and revenues payable, where the revenue has been reported but the cash has yet to be recorded should be separately reported on a gross basis.

\section{F. External Debt and Arrears}

13. As set forth in point No. 9 of the Guidelines on Performance Criteria with Respect to Foreign Debt (Decision No. 12274-00/85; August 24, 2000), the term "debt" will be understood to mean a current (i.e., not contingent) liability, created under a contractual arrangement through the provision of value in the form of assets (including currency) or services, and which requires the obligor to make one or more payments in the form of assets (including currency) or services, at some future point(s) in time; these payments will discharge the principal and/or interest liabilities incurred under the contract.

- $\quad$ Debts can take a number of forms, the primary ones being: (a) loans, (i.e., advances of money to obligor by the lender made on the basis of an undertaking that the obligor will repay the funds in the future-including deposits, bonds, debentures, 
commercial loans and buyers' credits - and temporary exchanges of assets that are equivalent to fully collateralized loans under which the obligor is required to repay the funds, and usually pay interest, by repurchasing the collateral from the buyer in the future (such as repurchase agreements and official swap arrangements);

(b) suppliers' credits (i.e., contracts where the supplier permits the obligor to defer payments until some time after the date on which the goods are delivered or services are provided); and (c) leases (i.e., arrangements under which property is provided that the lessee has the right to use for one or more specified period(s) of time that are usually shorter than the total expected service life of the property, while the lessor retains the title to the property). Excluded from this limit are leases of real property by Afghan embassies or other foreign representations of the government.

- $\quad$ For the purpose of the guideline, the debt is the present value (at the inception of the lease) of all lease payments expected to be made during the period of the agreement excluding those payments that cover the operation, repair, or maintenance of the property. Arrears, penalties, and judicially-awarded damages arising from the failure to make payment under a contractual obligation that constitutes debt are debt. Failure to make payment on an obligation that is not considered debt under this definition (e.g., payment on delivery) will not give rise to debt.

\section{The ceiling on medium- and long-term external debt applies on a continuous} basis to the contracting or guaranteeing by the government or DAB of new nonconcessional external debt with an original maturity of more than one year. For program purposes, "government" includes the central government (including government departments), as well as official agencies that do not seek profit and whose budgets are issued independent of the annual operational or development budgets. Consistent with the PFEM law, the Ministry of Finance (MOF) should have sole responsibility for the contracting and guaranteeing of external debt on behalf of the government.

- It applies to both debt as defined in paragraph 13 of this memorandum, and also to commitments contracted or guaranteed for which value has not been received. For the purposes of the program:

- external debt will be considered to have been contracted at the point the loan agreement or guarantee is signed by the MOF (on behalf of the government) or DAB Governor; and

- the guarantee of a debt arises from any explicit legal obligation of the government or $\mathrm{DAB}$, or any other agency acting on behalf of the government, to service such a debt in the event of nonpayment by the recipient (involving payments in cash or in kind), or indirectly through any other obligation of the government or DAB to cover a shortfall incurred by the loan recipient. 
- Excluded from the limits are refinancing credits and rescheduling operations, credits extended by the IMF, and credits on concessional terms defined as those with a grant element of at least 60 percent. The grant element is to be calculated using currencyspecific discount rates based on the Organization for Economic Cooperation and Development's Commercial Interest Reference Rates (CIRRs): for maturities of less than 15 years, the grant element will be calculated based on six-month averages of CIRRs; and for maturities longer than 15 years, the grant element will be calculated based on 10 year averages.

- Debt falling within the limit shall be valued in U.S. dollars at the exchange rate prevailing at the time the contract or guarantee becomes effective.

15. The zero ceiling on short-term external debt applies on a continuous basis to the stock of short-term external debt owed or guaranteed by the government (as defined in paragraph 14 of this memorandum) or $\mathrm{DAB}$, with an original maturity of up to and including one year.

- It applies to debt as defined in paragraph 13 of this memorandum.

- $\quad$ Excluded from the limit are rescheduling operations (including the deferral of interest on commercial debt) and normal import-related credits.

- Debt falling within the limit shall be valued in U.S. dollars at the exchange rate prevailing at the time the contract or guarantee becomes effective.

16. A continuous performance criterion applies to the nonaccumulation of new external payments arrears on external debt contracted or guaranteed by the central government or DAB. External payment arrears consist of external debt service obligations (principal and interest) falling due after March 20, 2006 and that have not been paid at the time they are due, as specified in the contractual agreements. Excluded from the prohibition on the accumulation of new arrears are: (a) arrears arising from interest on the stock of arrears outstanding as of March 20, 2006; and (b) external arrears that are subject to debt rescheduling agreements or negotiations.

G. Lending to, or Guaranteeing Borrowing by, State-Owned Enterprises

17. The zero ceiling on new lending from state-owned banks to, or government guaranteed borrowing by, enterprises in need of restructuring applies on a continuous basis.

- For the purposes of this performance criterion: 
- "state-owned banks" refers to those banks that are wholly or majority owned by the government (as defined in paragraph 14 of this memorandum); including Bank Millie, Bank Pashtany, and Export Promotion Bank;

- "enterprises in need of restructuring" refers to enterprises that meet any one of the following: (a) enterprises (public or private) that have not had an audited balance sheet in fiscal years 1384 and 1385; (b) public enterprises that have been identified by the MOF for liquidation; (c) public enterprises that do not have Cabinet-approved restructuring plans;

- "public enterprises" refers to enterprises wholly or majority owned by the government, including those covered by the State-Owned Enterprise (Tassady) Law, and 13 state-owned corporations ${ }^{3}$ and any other public entities and government agencies engaged in commercial activities but not covered by Tassady Law.

- It applies to any new loans (or financial contributions) extended directly from state-owned banks to enterprises in need of restructuring, and also to any new government guarantees (as defined in paragraph 14 of this memorandum) of borrowing undertaken by these enterprises. It applies to loan agreements and guarantees for which value has not been received.

\section{H. Adjustors}

18. The floor on NIR and the ceiling on the NCBF of the government are defined consistent with the assumption that core budget development spending in 2007/08 will amount, on a cumulative basis from March 20, 2007, to:

December 21, 2007 Af 27,063 million

March 19, 2008 Af 45,483 million

and in 2008/09 will amount on a cumulative basis from March 19, 2008, to:

June 20, 2008

September 21, 2008
Af 7,107 million

Af 21,320 million

\footnotetext{
${ }^{3}$ Afsotar, Afghan Teor, Aftento, Af-Turk, Afghan Cart, Afghan Naichi, Astrass, Afghan Telecom, Afghan Wireless, Afghan National Insurance Company, Afghan Textile, Ariana Afghan Airlines, and Hotel Intercontinental (Baghi Bala/Kabul).
} 
Should core budget development spending exceed these projections, the NIR floor will be adjusted downward and the NCBF ceiling will be adjusted upward by the difference between the actual level (up to the appropriated amount) and the projected level of development spending.

19. The NIR floor and NCBF ceiling are defined consistent with the assumption that the external financing of the core budget and the receipts from the sale or transfer of nonfinancial assets will amount, on a cumulative basis from March 20, 2007, to:

$$
\begin{array}{ll}
\text { December 21, } 2007 & \text { Af } 38,980 \text { million } \\
\text { March 19, 2008 } & \text { Af } 56,889 \text { million }
\end{array}
$$

and in 2008/09 will amount on a cumulative basis from March 19, 2008, to:

$$
\begin{array}{ll}
\text { June } 20,2007 & \text { Af } 10,742 \text { million } \\
\text { September 21, 2008 } & \text { Af } 28,161 \text { million }
\end{array}
$$

20. Should external financing of the core budget (including that associated with offbudgetary spending coming on budget) and the receipts from the sale or transfer of nonfinancial assets collectively exceed (fall short of) these projections, the NIR floor will be adjusted upward (downward) and the NCBF ceiling will be adjusted downward (upward) by the difference between their actual level and the projected level.

21. Should some expenditure currently financed directly by donors outside the budget be moved on to the operating budget, the NIR floor will be adjusted downward, and the NCBF ceiling and the indicative targets (ceilings) for the operating budget deficits of the central government, excluding grants, will be adjusted upward, by the actual amount of these expenditures on the conditions that (a) the moving on budget of these expenditures is justified by a statement from donors indicating their decision to stop financing them outside the budget and (b) they are subject to a supplementary appropriation approved by parliament.

The overall downward adjustment to the NIR floors will be capped at US\$300 million.

\section{Provision OF InFORMATION TO FUnd STAFF}

22. To facilitate the monitoring of program implementation, the government of Afghanistan and DAB will provide to Division A of the Middle East and Central Asia Department (MCD), through the office of the Resident Representative of the IMF in Afghanistan, the information specified below and summarized in the list of reporting tables provided by Fund staff to the Technical Committee. 
23. In order to facilitate regular monitoring of the PRGF-supported program, actual outcomes should be provided with the frequencies and lags indicated below.

- DAB net international reserves should be reported weekly, no later than two weeks after the end of the week.

- Monetary statistics, including exchange rates, government accounts with DAB, currency in circulation, and a monetary survey should be reported monthly and no later than three weeks after the end of the month. The monetary survey will include the balance sheet of DAB and a consolidated balance sheet of the commercial banking sector.

- Core budget operations and their financing should be reported monthly and no later than four weeks after the end of the month. The official reports for the purpose of program monitoring will be the monthly financial statements from the Afghanistan Financial Management Information System. The structure of financing (grants and loans should be separately identified) and expenditure data should be on a consistent cash basis. Core operating expenditures should be reported on a monthly basis using the budget appropriation economic (object) and administrative classification in addition to the program and functional classification as reported in the budget documents. Core development expenditures should also be reported separately on a monthly basis using the budget program classification in addition to the economic (object), administrative and functional classification consistent with the operating budget. All the data should also compare outturns against the approved budget

(or figures reported in the budget documents). Core operating and development revenues and expenditures should also be reported by province, separately on the same monthly basis.

- $\quad$ External budget operations and their financing (i.e., donor funded spending outside the core budget treasury systems) should be reported at least semi-annually (more frequently if possible) and no later than eight weeks after the end of the period. External development expenditures should be reported on a disbursement basis (as currently defined in budget documents) using the budget program classification (and an administrative, functional and provincial classification where possible).

- External debt data should be reported quarterly and no later than six weeks after the end of the quarter. They will include: (a) details of new loans contracted or guaranteed during the quarter, including the terms of each new loan; (b) the stock of debt at the end the quarter, including short-term debt, and medium- and long-term debt; (c) loan disbursements and debt service payments (interest and amortization) during the quarter; (d) debt relief received during the quarter; (e) information on all overdue payments on short-term debt, and on medium- and long-term debt, including new external arrears (if any); and (f) total outstanding amount of arrears. 
- National accounts data, with the exception of merchandise trade data, should be reported annually and no later than eight weeks after the end of the year. Merchandise trade data should be reported quarterly and no later than eight weeks after the end of the quarter.

- Consumer price indexes (CPIs) for the city of Kabul and for Kabul and five other major cities ("national" CPI) should be reported monthly and no later than four weeks after the end of the month.

24. The government of Afghanistan and DAB will prepare and send to the IMF reports explaining progress made in implementing structural reforms, in particular regarding those included as structural performance criteria and benchmarks in the program. These reports will include appropriate documentation to substantiate progress achieved, and will explain any deviations relative to the initial reform plans or timetable, specifying expected revised completion date.

25. Other details on major economic and social measures taken by the government that are expected to have an impact on program sequencing (such as changes in legislation, regulations, or any other pertinent document) will be sent in a timely manner to IMF staff, for consultation or information.

26. The Technical Committee of Coordination (TCC) will provide Division A of MCD with any other information that may be required by the staff of the IMF for the effective monitoring of the program. For program monitoring purposes, working meetings are planned, at least biweekly, with the participation of representatives of the designated members of the TCC, including any party that could facilitate monitoring implementation of the program. 


\title{
INTERNATIONAL MONETARY FUND
}

\author{
ISLAMIC REPUBLIC OF AFGHANISTAN
}

Staff Report for the 2007 Article IV Consultation and Third Review Under the Three-Year Arrangement Under the Poverty Reduction and Growth Facility, and Request for a Waiver of Performance Criterion

\section{Informational Annex}

Prepared by Middle East and Central Asia Department

(In consultation with other Departments)

January 28, 2008

Contents

Page

I. Relations with the Fund ................................................................................... $\underline{2}$

II. Relations with the World Bank ................................................................... 7

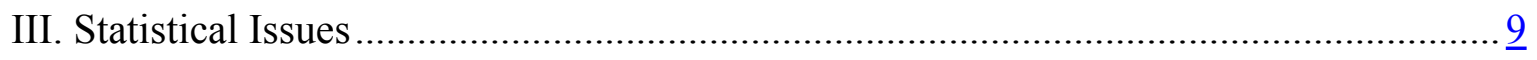


ANNEX I. ISLAMic Republic OF AfGHANistan-Relations With THE FUnd

(As of December 31, 2007)

I. Membership Status: Joined July 14, 1955; Article XIV.

II. General Resources Account

Quota

Fund holdings of currency

Reserve position in Fund

Holdings Exchange Rate

III. SDR Department

Net cumulative allocation

Holdings

IV. Outstanding Purchases and Loans

PRGF Arrangements

\begin{tabular}{rr} 
SDR Million & \% Quota \\
\hline 161.90 & 100.00 \\
161.92 & 100.01 \\
0.00 & 0.00
\end{tabular}

$\underline{\text { SDR Million }}$

26.70

$\%$ Allocation

100.00

0.20

0.77

$\underline{\text { SDR Million }}$

35.80

$\%$ Quota

22.11

V. Latest Financial Arrangements:

\begin{tabular}{|c|c|c|c|c|}
\hline Type & $\begin{array}{l}\text { Date of } \\
\text { Arrangement }\end{array}$ & $\begin{array}{l}\text { Expiration } \\
\text { Date }\end{array}$ & $\begin{array}{c}\text { Amount Approved } \\
\text { (SDR Million) }\end{array}$ & $\begin{array}{r}\text { Amount Drawn } \\
\text { (SDR Million) }\end{array}$ \\
\hline PRGF & June 26, 2006 & June 25, 2009 & 81.00 & 35.80 \\
\hline
\end{tabular}

VI. Projected Payments to Fund

(SDR million; based on existing use of resources and present holdings of SDRs)

\begin{tabular}{llllll} 
& \multicolumn{5}{c}{ Forthcoming } \\
\cline { 2 - 5 } & $\underline{2008}$ & $\underline{2009}$ & $\underline{2010}$ & $\underline{2011}$ & $\underline{2012}$ \\
Principal & $\underline{1.11}$ & $\underline{1.11}$ & $\underline{1.11}$ & $\underline{1.11}$ & $\underline{1.11}$ \\
Total & $\underline{1.11}$ & $\underline{1.11}$ & $\underline{1.11}$ & $\underline{1.11}$ & $\underline{3.56}$
\end{tabular}

VII. Implementation of HIPC Initiative:

Enhanced

Framework

Commitment of HIPC assistance

July 2007 
Assistance committed (NPV terms) ${ }^{1}$

by all creditors (US\$ million)

571.40

Of which: Fund assistance (US\$ million)

(SDR equivalent in million)

Completion point date

$--$

$--$

Floating

\section{Implementation of MDRI Assistance: Not Applicable}

\section{Nonfinancial Relations}

\section{Exchange Arrangement}

Afghanistan is an Article XIV member country. The authorities are implementing a liberal exchange system. Based on information currently available to the staff, no exchange restrictions and multiple currency practices are currently in place. The authorities have provided documents to IMF staff related to laws and regulations on the exchange regime and have requested technical assistance from the Fund to formalize the current liberal regime. They have been implementing a managed float system with no predetermined path for the exchange rate. On January 16, 2008, the average of the buying and selling exchange rates in cash transactions on the Kabul money exchange market was Af 49.47 per $\$ 1$.

To conduct monetary policy, the authorities rely on foreign exchange auctions since May 2002, and on short-term capital note auctions since September 2004. The foreign exchange auctions were initially open only to licensed money changers, but since June 2005 they are also open to commercial banks. The capital note auctions are open to commercial banks. Auctions are linked to the overall monetary program and are held on a regular basis (biweekly for foreign exchange auctions, daily for capital note auctions).

\section{Article IV Consultation}

The last Article IV consultation with Afghanistan was discussed by the Executive Board on March 6, 2006. Consultations with Afghanistan are on the standard 12-month cycle.

\section{Safeguards Assessment}

Under the Fund's safeguards assessment policy, Da Afghanistan Bank (DAB) is subject to a safeguards assessment with respect to PRGF arrangement approved on June 26, 2006. A safeguards assessment of DAB completed on June 12, 2006 revealed serious vulnerabilities in DAB's external and internal audit mechanisms, as well as in its financial

\footnotetext{
${ }^{1}$ Net Present Value (NPV) at the decision point under the enhanced framework.
} 
reporting framework and system of internal controls. Capacity constraints, however, hampered the effective implementation of measures recommended by the assessment, and a follow-up staff visit conducted in November 2007 found that while external audit arrangements have been strengthened, financial reporting and internal controls were insufficient to ensure the accuracy of monetary data, and the accounting system remained unreliable. To provide some assurances ahead of the next review of the PRGF arrangement, the mission recommended that a special audit of reserve assets be conducted as a prior action for the completion of the review.

XII. Technical Assistance, 2005-07

\begin{tabular}{|c|c|c|}
\hline Department & Date & Purpose \\
\hline \multirow[t]{9}{*}{ FAD } & March 2004-July 2006 & Resident treasury expert \\
\hline & May 19-25, 2005 & Seminar on reorganization of the MOF \\
\hline & October $18-25,2005$ & Tax policy \\
\hline & February 21-March 04, 2006 & Public financial management \\
\hline & April 30-May 09, 2006 & Tax policy \\
\hline & November 15-23, 2006 & Tax and customs administration \\
\hline & August $18-30,2007$ & Program budgeting \\
\hline & August 28-September 12, 2007 & GFS \\
\hline & October 2007-September 2008 & Resident Treasury Advisor \\
\hline \multirow[t]{2}{*}{ FIN } & April 2-11, 2006 & Safeguards assessment \\
\hline & November 9-12, 2007 & Safeguards assessment \\
\hline LEG & January 29-February 12, 2005 & Income tax law \\
\hline LEG/MCM & May 2-10, 2006 & $\begin{array}{l}\text { Legal framework of DAB's monetary and } \\
\text { payment system policies }\end{array}$ \\
\hline \multirow[t]{10}{*}{$\mathrm{MCM}$} & September 2004-April, 2006 & Training coordinator \\
\hline & April 2006-June 2007 & Training coordinator (peripatetic) \\
\hline & February $2-15,2005$ & $\begin{array}{l}\text { Implementation of DAB balance sheet } \\
\text { reconstruction and capital adequacy } \\
\text { recommendations }\end{array}$ \\
\hline & May $16-25,2005$ & Monetary policy and financial markets \\
\hline & October 11-20, 2005 & Monetary policy \\
\hline & November 20-29, 2005 & Financial markets \\
\hline & January 22-February 5, 2006 & Monetary policy \\
\hline & January 22-February 5, 2006 & Monetary policy \\
\hline & May $2-10,2006$ & $\begin{array}{l}\text { Monetary policy, foreign reserve } \\
\text { management, money markets and } \\
\text { insurance }\end{array}$ \\
\hline & November 28-December 10, 2006 & $\begin{array}{l}\text { Monetary policy formulation and } \\
\text { implementation }\end{array}$ \\
\hline
\end{tabular}




\begin{tabular}{|c|c|c|}
\hline Department & Date & Purpose \\
\hline \multirow[t]{3}{*}{$\mathrm{MCM}$} & March 19-April 16, 2007 & Central bank capacity building \\
\hline & March 24-29, 2007 & Banking supervision \\
\hline & April 17-30, 2007 & $\begin{array}{l}\text { Monetary policy formulation and } \\
\text { implementation }\end{array}$ \\
\hline \multirow[t]{16}{*}{ STA } & January $15-$ February 15,2005 & Multisector statistics \\
\hline & March 23-June 11, 2005 & Multisector statistics \\
\hline & July 20-August 31,2005 & Multisector statistics \\
\hline & October 31, 2005-January 12, 2006 & Multisector statistics \\
\hline & March 6-15, 2006 & Balance of payments statistics \\
\hline & March 8-May 2, 2006 & Multisector statistics \\
\hline & March13-April 1, 2006 & Monetary and financial statistics \\
\hline & May 24-July 18, 2006 & Multisector Statistics \\
\hline & August 2-16, 2006 & Balance of payments statistics \\
\hline & August 8-October 3, 2006 & Multisector statistics \\
\hline & September 22-October 4, 2006 & Government finance statistics \\
\hline & November 1-December 26, 2006 & Multisector statistics \\
\hline & November 5-19, 2006 & Monetary and financial statistics \\
\hline & April 22-May 4, 2007 & Monetary and financial statistics \\
\hline & July 7-30, 2007 & National accounts \\
\hline & August 29-September 25, 2007 & National accounts \\
\hline MCD & April 16-20, 2005 & $\begin{array}{l}\text { Basic macroeconomic accounting and } \\
\text { financial programming }\end{array}$ \\
\hline \multirow[t]{13}{*}{ METAC } & November $15-20,2005$ & Tax policy and administration \\
\hline & June 2006 & Budget integration \\
\hline & November-December 2006 & Budget integration \\
\hline & December 2006 & Cash management \\
\hline & March 2007 & Cash management \\
\hline & May 19-25, 2007 & Balance of payments statistics \\
\hline & June 6-19, 2007 & Accounting \\
\hline & July 1-10, 2007 & Banking supervision \\
\hline & August 2007 & $\begin{array}{l}\text { Cash management and program } \\
\text { budgeting }\end{array}$ \\
\hline & September 2-17, 2007 & Central bank accounting \\
\hline & November 13-December 4, 2007 & Central bank accounting \\
\hline & November 4-8, 2007 & Banking supervision \\
\hline & November 6-15, 2007 & Banking supervision \\
\hline
\end{tabular}

Afghanistan is a participant in the Middle East Technical Assistance Center.

With financial support from the Sweden Technical Assistance Subaccount, the Fund sponsored a number of training activities aimed at DAB officials. A long-term resident training advisor, Mr. Khan, was posted at DAB from September 2004-April 2006 and is 
now conducting peripatetic technical assistance missions. Finally, Sweden has financed a monetary policy peripatetic advisor (a position currently shared by Mr. Coats and Mr. Gray) to assist DAB in developing the strategy and instruments for improving the implementation of monetary policy.

\section{Resident Representatives}

During the first half of 2002, the Fund's resident representative in Pakistan, Mr. Ghesquière, assisted in maintaining relations with the Afghan authorities. A resident representative, Mr. de Schaetzen, took up his post in Kabul on August 24, 2002. Mr. Charap succeeded him on June 13, 2005. 


\title{
AnNex II. Islamic Republic of Afghanistan-Relations With the World Bank
}

\author{
(As of January 9, 2008)
}

1. The Interim Strategy Note (ISN) discussed by the IDA Board of Executive Directors on May 25, 2006 follows the two Transitional Support Strategies (TSS) that covered the 2002-06 periods. It is guiding IDA's engagement in Afghanistan over the period of 2006-08 and is expected to be followed by a full Country Assistance Strategy (CAS) once the Government has finalized its full PRSP-Afghanistan National Development Strategy which is expected to be completed in March 2008. The government promulgated its Interim Afghanistan National Development Strategy (I-ANDS) in January 2006. As the government had submitted the I-ANDS to the IMF and the World Bank as its Interim Poverty Reduction Strategy (I-PRSP), Bank and Fund staff prepared a Joint Staff Advisory Note (JSAN) which was also discussed by the Bank Board on May 25, 2006. The ISN focus shifts slightly from the previous TSS, notably to provide greater emphasis on the development of the rural economy. Its pillars are: (i) build the capacity of the state and its accountability to its citizens to ensure the provision of services that are accountable, accessible, and of adequate quality; (ii) promote growth of the rural economy and improve rural livelihoods; and (iii) support growth of a formal, modern, and competitive private sector.

2. As of January 9, 2008 the World Bank had committed an aggregate of US\$1.6 billion in IDA assistance to Afghanistan, financing more than 30 projects covering public administration, infrastructure, education, health, customs, transport, and rural development. Three IDA projects closed in FY 2007 (i.e. July 2006-June 2007) and two have closed thus far in FY08. Most recently, the Board approved, in January 2008, a US\$30 million IDA investment in microfinance. Together with the HIV/AIDS project and the National Rural Access Program this takes FY08's commitments to date to US\$152 million with three more planned for board approval, including projects for skills development, educational improvement and Kabul urban waste.

3. As of December 31, 2007, the IDA's active portfolio comprised 21 investment projects with combined net commitments of US $\$ 1,016$ million of which 48 percent had been disbursed. In terms of sectoral composition of the overall portfolio, rural and transport sectors continue to represent the two largest shares, with respect to both commitments and disbursements. This is largely due to the successful implementation of the two nation-wide programs: National Solidarity Program (NSP) that supports development of community demand-driven rural infrastructure and community level governance, and the National Emergency Employment Program (NEEP) that provides short-term employment opportunities to the vulnerable segments of rural population through rural roads rehabilitation and reconstruction.

4. The World Bank also administers the Afghanistan Reconstruction Trust Fund (ARTF), on behalf of 27 donors, which became effective in May 2002. The ARTF is the main mechanism for providing coordinated funding support to Afghanistan's recurrent 
budget, as well as investments through the Core Development Budget in line with agreed budget priorities of the Government. In the previous Solar Year 1386 (2005/06), the ARTF mobilized over US $\$ 450$ million, while cumulative disbursements reached US\$468 million. This Solar Year through November 2007, contributions have reached US\$455 million and disbursements US\$297 million.

5. As of 21 November, 2007, paid-in donor contributions to the ARTF reached US\$ 2.4 billion. As of 21 November, 2007 the ARTF investment window financing comprised 11 active projects with combined commitments of US\$394 million, of which US\$263 million had been disbursed. The National Solidarity Program II and the Microfinance are the two fast-disbursing programs in the ARTF current investment portfolio. The new Management Capacity Program was added to the ARTF active portfolio in FY 2007. The Bank also administers a special window for Afghanistan for the Japanese Social Development Fund of US\$50 million. ARTF is increasing its financing of investments and has the potential to support better donor coordination, simplified processes, and fast results.

6. The World Bank is also actively engaged in providing analytical and advisory services to the government. Current and recent analytical work has focused on civil service reform, urban development and land management, education policy reform, labor market and pensions, oil/gas infrastructure development, and the drug economy, as well as broader regional trade work encompassing issues with Afghanistan's neighbors. A Gender Assessment was released in January 2006. The World Bank completed a major Public Finance Management (PFM) review in 2006, which incorporates an assessment of civilian public expenditures and fiduciary aspects, including procurement and financial management, as well as revenue and security sector expenditures. Fund staff contributed to the PFM review, including by providing an analysis of domestic revenue prospects. Technical assistance on pensions and three major analytical tasks, on Public Administration Reform, on Fighting Corruption, and on Sub-National Administration are underway in response to government requests. Looking ahead, the pipeline for FY09 includes work on financial sector reform and rural enterprise development. 


\section{AnNeX III. Islamic RePUblic Of AfGHanistan: Statistical IsSUES}

\section{General}

1. Data are broadly adequate for surveillance and program monitoring, although statistical weaknesses remain. The statistical system has improved since 2002; nonetheless, organizational weaknesses, poor staffing, and lack of equipment continue to hamper the compilation process. Due to security reasons and limited central government influence outside Kabul, setting up a nationwide statistical system has been a difficult undertaking. While the Central Statistics Office (CSO) has regional offices, staffing and communication are poor. Staffing in most agencies is inadequate both in number and expertise, and salaries remain low. Strengthening statistical capacity is an ongoing process and greater efforts and significant institutional support will be required if further substantial improvements are to be made. STA continues to provide technical assistance through peripatetic statistical advisors as well as short-term topical missions.

2. The authorities have restructured the CSO, but many key donors involved in preparing the statistical master plan (SMP) have expressed concern over the independence of the CSO, which now reports to the Ministry of National Economy, and the integrity of the statistical system. Progress on the implementation of the SMP has been delayed, as the authorities have been slow in undertaking the required institutional changes and strengthening the management structure of the CSO.

3. The authorities have been participating in the General Data Dissemination System (GDDS) since June 2006.

\section{Real Sector}

4. The national accounts compilation process is hampered by the general lack of source data. The Asian Development Bank (AsDB) provided funding for two major surveys that could supply critical source data for the national accounts; however, the survey fieldwork has been delayed. The AsDB has suspended funding of TA projects in Afghanistan and the future of these surveys is uncertain.

5. The CSO now compiles a nationwide CPI covering Kabul and the five major cities. Nonetheless, the inexperience of price collectors has posed some early challenges to the compilation process. There is also the need to update the expenditure weights as the current CPI basket was derived from a 1987 household income and expenditure survey. In 2003, the CSO conducted a limited exercise to update the weights based on household expenditure in Kabul; however, a comprehensive exercise to obtain representative weights is required, and is predicated on the completion of an integrated living standard survey.

6. Customs coverage of overland foreign trade - which is most of foreign trade - is limited at best. The CSO currently records trade at only seven of the 14 customs posts. Monthly trade data are updated manually, thereby causing delays in dissemination. Accordingly, there is an urgent need for improved computer hardware. 


\section{Government Finance Statistics}

7. An STA expert has been assisting the Ministry of Finance (MOF) in compiling government finance statistics, achieving considerable progress. The tables reported for publication in the Government Finance Statistics Yearbook 2006 incorporate for the first time data on extra-budgetary agencies, donor expenditure made on behalf of the government, and the operations of municipalities. Nevertheless a number of weaknesses remain, including a very limited technical capacity of the MOF's staff, inadequate classification systems in use by municipalities, deficiencies in the functional classification of government expenditure, and a lack of consistency and comprehensiveness in the data compiled.

\section{Money and Banking Statistics}

8. The banking sector has developed steadily over the last several years. In addition to three state-owned banks in the process of restructuring, twelve commercial banks are now in operation. While there was some improvement in the scope and quality of data reporting by the central bank, there are still weaknesses in many areas. Da Afghanistan Bank (DAB) has installed a new accounting software, which allows DAB to produce its balance sheet at least on a monthly basis. The very limited accounting capacity of DAB, especially outside Kabul has hindered efforts to produce a complete and reliable balance sheet. Regarding the commercial banks, DAB has developed new reporting formats to provide data for bank supervision and monetary statistics compilation, and the banks are now reporting data to DAB regularly according to these formats. STA has assisted DAB (four expert visits took place between March 2006 and November 2007) in bringing the data reporting of DAB and the commercial banks in compliance with the methodology in the IMF's Monetary and Financial Statistics Manual.

9. The authorities have expressed interest in reintroducing a country page for Afghanistan in International Financial Statistics (IFS). A STA expert has assisted DAB in drafting a country note and initiating data reporting for publication in IFS. Provided that DAB is able to compile and report data (Standardized Report Forms 1SR, 2SR, and 5SR) to STA on a regular monthly basis, an IFS page for Afghanistan could be introduced in early 2008.

\section{Balance of Payments}

10. Like the national accounts, compilation of balance of payments statistics suffers from a paucity of source data. There are no estimates of unrecorded border trade, which constitutes a significant proportion of foreign trade. No reliable source data exist to estimate services, income, transfers, and foreign direct investment. A balance of payments statistics mission (May 19-25, 2007) found that source data are extremely weak and that survey initiatives have not materialized in any significant data output due to poor responses, sampling problems, and a lack of human, financial, and technological resources. The mission found that limited progress had been made on the work program initiated in August 2006. Outstanding issues include: 
- $\quad$ Adopt legal measures that give DAB the authority to collect data from other sectors, other than banks, and ensure the confidentiality of reported data.

- $\quad$ Estimate exports and imports based on CSO data with adjustment for illegal trade and duty free imports. The CSO should start including duty free imports according to international classifications.

- $\quad$ Adjust freight and insurance at 12 and 3 percent, respectively, of c.i.f. imports from overseas to calculate imports f.o.b.

- Introduce questionnaire to hotels and guesthouses to collect data on expenses of nonresidents to estimate travel receipts.

- $\quad$ Conduct sample surveys of residents returning from travel abroad and use immigration data to estimate travel expenses.

- Introduce a questionnaire for collecting data from foreign embassies and other foreign organizations to estimate government receipts and compensation of employees.

- Improve the questionnaire on foreign direct investment (FDI) to collect relevant data from major FDI enterprises.

- Introduce reporting forms for foreign exchange transactions between residents and nonresidents to commercial banks, following discussions with the Banking Supervision Department of the DAB.

- Introduce a questionnaire for money changers and money transfer service providers.

- Enhance the collection of quarterly data from the Ministry of Economy on NGOs' receipts of donations and grants.

- Compile preliminary balance of payments statistics on the basis of various estimation procedures discussed with and documented by the Balance of Payments Section.

A follow-up STA mission in October/November 2007 noted some improvements in the area of source data and in the cooperation between agencies. The mission's main recommendations were to: (1) review the reporting forms in the area of services as provided by the mission and implement these as needed; (2) compile the financial account related transactions for the commercial banks based on the forms as agreed with the Banking Supervision Department; (3) compile DAB related transactions using the reporting form provided by the mission; (4) continue compiling international reserves data consistent with the fifth edition of the Balance of Payments Manual (BPM5) as compiled during the mission and provide these to the IMF for publication in the International Financial Statistics (IFS); and (5) agree with Afghan Investment Support Agency to conduct an FDI survey. An action plan was agreed upon with the authorities, with targeted dates for implementation. Furthermore, DAB will report on a monthly basis to STA the progress regarding processing and compiling balance of payments statistics. The mission will continue to provide remote TA. Future TA missions will depend on DAB completing specified benchmarks three months after the end of the mission. 


\section{External Debt}

Many records were destroyed during the war and the authorities are slowly rebuilding their database. Nevertheless, significant progress in terms of reconciliation has been made in the context of the July 2006 Paris Club rescheduling. Progress is also being made in reconciling debts to non-Paris Club creditors. 
Islamic Republic of Afghanistan: Table of Common Indicators Required for Surveillance (As of January 16, 2008)

\begin{tabular}{|c|c|c|c|c|c|}
\hline & $\begin{array}{c}\text { Date of latest } \\
\text { observation }\end{array}$ & $\begin{array}{l}\text { Date } \\
\text { received }\end{array}$ & $\begin{array}{l}\text { Frequency } \\
\text { of } \\
\text { Data 6/ }\end{array}$ & $\begin{array}{l}\text { Frequency } \\
\text { of } \\
\text { Reporting 6/ }\end{array}$ & $\begin{array}{c}\text { Frequency } \\
\text { of } \\
\text { Publication 6/ }\end{array}$ \\
\hline Exchange Rates & $1 / 16 / 08$ & $1 / 16 / 08$ & $\mathrm{D}$ & $\mathrm{D}$ & $\mathrm{D}$ \\
\hline $\begin{array}{l}\text { International Reserve Assets and Reserve } \\
\text { Liabilities of the Monetary Authorities 1/ }\end{array}$ & $11 / 21 / 07$ & $12 / 20 / 07$ & M & M & M \\
\hline Reserve/Base Money & $9 / 22 / 07$ & $10 / 20 / 07$ & M & M & M \\
\hline Broad Money & $9 / 31 / 07$ & $11 / 1 / 07$ & M & M & M \\
\hline Central Bank Balance Sheet & $11 / 21 / 05$ & $12 / 20 / 07$ & M & M & M \\
\hline $\begin{array}{l}\text { Consolidated Balance Sheet of the Banking } \\
\text { System }\end{array}$ & $9 / 31 / 07$ & $11 / 1 / 07$ & Q & Q & Q \\
\hline Interest Rates 2/ & $1 / 01 / 07$ & $1 / 10 / 07$ & $\mathrm{D}$ & A & A \\
\hline Consumer Price Index & $12 / 07$ & $01 / 10 / 07$ & M & M & M \\
\hline $\begin{array}{l}\text { Revenue, Expenditure, Balance and } \\
\text { Composition of Financing } 3 / \text {-General } \\
\text { Government } 4 /\end{array}$ & -- & -- & -- & -- & -- \\
\hline $\begin{array}{l}\text { Revenue, Expenditure, Balance and } \\
\text { Composition of Financing } 3 /- \text { Central } \\
\text { Government }\end{array}$ & $11 / 07$ & $12 / 07$ & M & M & M \\
\hline $\begin{array}{l}\text { Stocks of Central Government and Central } \\
\text { Government-Guaranteed Debt 5/ }\end{array}$ & -- & -- & -- & -- & -- \\
\hline External Current Account Balance & 2007/08 Q2 & $11 / 01 / 08$ & Q & Q & Q \\
\hline Exports and Imports of Goods and Services & 2007/08 Q2 & $11 / 01 / 08$ & Q & Q & Q \\
\hline GDP/GNP & 2006/07 & $6 / 15 / 07$ & A & A & A \\
\hline Gross External Debt & 2007/08 Q2 & $11 / 01 / 08$ & Q & Q & Q \\
\hline
\end{tabular}

1/ Includes reserve assets pledged or otherwise encumbered as well as net derivative positions.

2/ Both market-based and officially-determined, including discount rates, money market rates, and rates on treasury bills, notes and bonds.

3/ Foreign, domestic bank, and domestic nonbank financing.

4/ The general government consist of the central government (budgetary funds, extra budgetary funds, and social security funds) and state and local governments.

$5 /$ Including currency and maturity composition.

6/ Daily (D); weekly (W); monthly (M); quarterly (Q); annually (A); irregular (I); and not available (NA). 


\section{Statement by the IMF Staff Representative on Islamic Republic of Afghanistan February 13, 2008}

1. This statement summarizes information that became available since the issuance of the staff report on January 29, 2008. Staff visited Kabul during January 26-February 5, 2008 to assess Afghanistan's performance with respect to the indicative quantitative targets under the PRGF-supported program through December 2007, and to reach understandings on corrective measures to address a revenue shortfall. The new information does not change the thrust of the staff appraisal.

2. The three prior actions for the completion of the third review under the PRGF arrangement have been implemented. President Karzai issued a decree approving the appointment of KPMG as Da Afghanistan Bank's (DAB) external auditor until 2010/11, and a special audit confirmed DAB's foreign exchange reserves, as reported to the Fund at the September 2007 test date. The authorities have also made the legislative changes necessary to eliminate the discriminatory application of the 1 percent tariff rate on imports of raw materials.

3. Performance under the program during the third quarter of $2007 / 08$ shows some slippages (see Table). Specifically, the indicative floor on fiscal revenue and the ceiling on currency in circulation $(\mathrm{CiC})$ were each missed by approximately Af 1 billion ( 0.2 percent of GDP). Prudent execution of the core operating budget permitted observance of the indicative targets on the operating budget deficit and net central bank financing of the government, but the revenue shortfall underscores the need to implement promptly measures to bolster revenue collection, as agreed with staff during the November 2007 mission.

4. Higher prices of imported fuel and foodstuffs led to a significant increase in consumer prices, with 12-month (end-of-period) inflation reaching 17 percent in December 2007. Following increased reliance on auctions of foreign exchange and capital notes (CNs) to absorb excess liquidity, the Afghani has appreciated by 1 percent against the U.S. dollar since end-December 2007.

5. In early February 2008, the authorities implemented the measures covered by the structural benchmarks for end-November 2007 that had been delayed, including the issuance of regulations on credit-granting standards and the credit-monitoring process, and on setting limits on sectoral loan concentration. DAB also proceeded expeditiously with the issuance of two circulars informing banks of changes to the minimum capital requirement and repealing the requirement to invest 80 percent of bank deposits domestically.

6. Regarding the draft 2008/09 operating budget, expenditure exceeds the level agreed with Fund staff in November 2007 by Af 2 billion ( 0.4 percent of GDP), on account of the contingency for accelerating recruitment by the Afghan National Army. The authorities also reallocated the cash fuel allowance of Af 1.5 billion for the Ministry 
of Interior to other expenditure items following commitments of offsetting in-kind donations. In addition, there has been a reallocation of expenditure from operation and maintenance to salaries. The operating budget envelope will be reevaluated at the time of the fourth review.

7. $\mathrm{DAB}$ recognizes the need to improve liquidity management to ensure that the March 2008 ceiling on $\mathrm{CiC}$ is observed. To that end, DAB is engaging the Ministry of Finance (MOF) in efforts to improve the projection of the government's cash-flow needs. As noted above, consistent with program understandings, DAB has already increased the issuance of CNs. It is also preparing the legal framework for the secondary market in these instruments, with Fund technical assistance.

8. The authorities and the World Food Program (WFP) have launched a joint appeal to distribute wheat to areas affected by shortages. Additional efforts to mitigate the effect of rising prices may, however, be necessary. Staff stressed the advantages of targeted cash transfers to vulnerable households. 
Islamic Republic of Afghanistan: Performance Criteria and Indicative Targets for 2007/08 1/ (Cumulative changes from March 20, 2007; unless otherwise indicated)

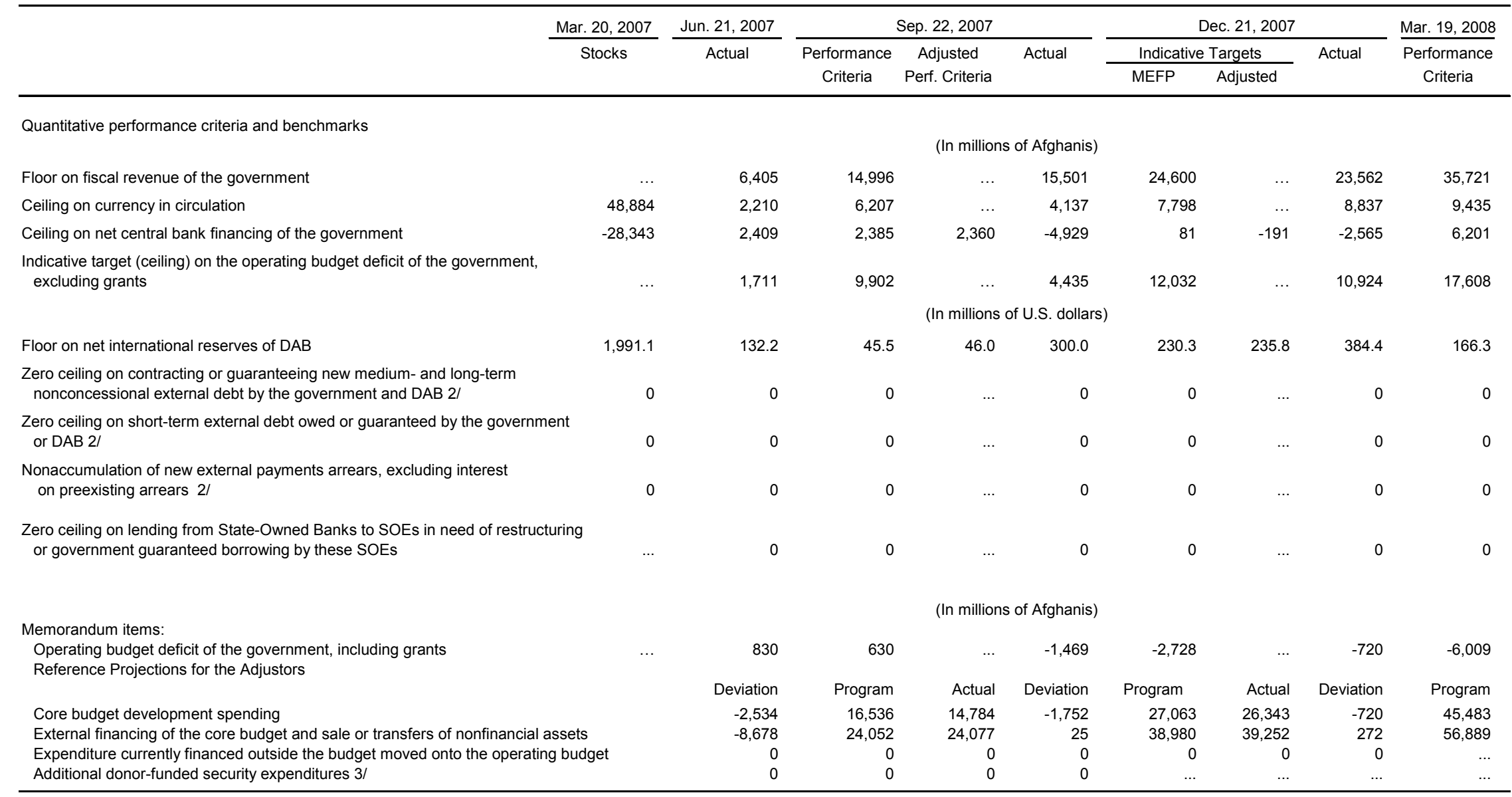

Sources: Afghan authorities; and Fund staff estimates and projections.

1/ The performance criteria and indicative targets envisaged under the program, and their adjustors, are defined in the Technical Memorandum of Understanding.

2/ These performance criteria apply on a continuous basis.

$3 /$ The program provided for additional Af 3,800 million in the first half of 2007/08 in donor-supported security spending. At the midyear review, the additional security spending was incorporated in the budget. 


\section{INTERNATIONAL MONETARY FUND}

EXTERNAL

Public Information Notice

RELATIONS

DEPARTMENT

Public Information Notice (PIN) No. 08/24

FOR IMMEDIATE RELEASE

February 20, 2008

International Monetary Fund

$70019^{\text {th }}$ Street, NW

Washington, D. C. 20431 USA

\section{IMF Executive Board Concludes 2007 Article IV Consultation with the Islamic Republic of Afghanistan}

On February 13, 2007, the Executive Board of the International Monetary Fund (IMF) concluded the Article IV consultation with the Islamic Republic of Afghanistan. ${ }^{1}$

\section{Background}

Since its approval by the Executive Board in June 2006 the three-year Poverty Reduction and Growth Facility (PRGF) arrangement (amounting to SDR 81 million) has helped maintain macroeconomic stability and has contributed to the implementation of the government's reform agenda. The arrangement supports the authorities' economic program through March 2009 and Afghanistan's participation in the enhanced Heavily Indebted Poor Countries (HIPC) Initiative.

The authorities have made good progress in the key policy areas covered by program conditionality. They have strengthened the Medium-Term Fiscal Framework, enhanced revenue efforts through tax reforms and capacity building, and improved implementation of the development budget. They also continue to strengthen the monetary policy framework and banking supervision. With regard to the broader reform agenda, however, performance has been mixed. There have been pressures for protectionist measures, while laws critical for private sector development have not yet been approved and the privatization of state-owned enterprises has proceeded at a slow pace. Moreover, the volatile security situation and the

\footnotetext{
${ }^{1}$ Under Article IV of the IMF's Articles of Agreement, the IMF holds bilateral discussions with members, usually every year. A staff team visits the country, collects economic and financial information, and discusses with officials the country's economic developments and policies. On return to headquarters, the staff prepares a report, which forms the basis for discussion by the Executive Board. At the conclusion of the discussion, the Managing Director, as Chairman of the Board, summarizes the views of Executive Directors, and this summary is transmitted to the country's authorities.
} 
increasing importance of the drug economy are weakening attempts at broadening economic development.

While the PRGF-supported program remains on track, it has been strengthened to address the risks emerging from: (i) government involvement in the domestic petroleum market; (ii) potential fiscal drains stemming mainly from the government's relations with public enterprises; and (iii) a weak supervisory and regulatory framework for the banking system.

Real GDP growth (excluding the drug economy) dropped to 6.1 percent in fiscal year 2006/07 owing to drought, but is expected to exceed 13 percent in 2007/08, reflecting a post-drought rebound in agricultural output and strong growth in other sectors, particularly construction. Inflation averaged 5.1 percent in 2006/07 but returned to double-digit levels in 2007/08 owing to sharp increases in the prices of imported fuel and foodstuffs. The Afghani has remained broadly stable against the U.S. dollar.

Revenue efforts have played a central role in improving the underlying fiscal position. Domestic revenues have increased markedly from an extremely low base of 4.7 percent of GDP in the fiscal year 2003/04, and are projected at 8.2 percent in 2007/08. This increase, combined with a prudent expenditure policy under the core budget (covering operating and development expenditures of the central government) have led to a gradual reduction in the core operating budget deficit (excluding grants) since 2004/05. The bulk of public expenditures, however, continue to be undertaken in the context of the external budget, which is executed and fully financed by donors.

Monetary policy has remained broadly consistent with the program and continues to be guided by indicative targets for currency in circulation, within the context of a managed float exchange system. With ample foreign exchange at its disposal, the Da Afghanistan Bank (DAB) relies primarily on foreign exchange auctions for managing liquidity. Limited use has been made of DAB's capital notes, which were introduced in mid-2004/05, as a liquidity absorption instrument. Foreign currencies and Afghanis continue to be used interchangeably in domestic transactions.

The external position remains dependant on large aid inflows. Official transfers were estimated at 66 percent of GDP in 2006/07, reflecting mainly higher security spending by donors. Afghanistan's debt sustainability has improved significantly as a result of debt relief from its bilateral creditors and interim debt relief under the HIPC Initiative. International reserves have increased steadily.

Banking sector activities have grown considerably over the last few years, mainly due to the expansion of private banking. This rapid growth has prompted DAB to strengthen its bank supervision capabilities. The bulk of activities of the banking sector are in foreign currencies. The preparation of the Afghanistan National Development Strategy (ANDS) has reached an advanced stage. The authorities intend to submit the full ANDS document to the Boards of the IMF and the World Bank by March 2008. 


\section{Executive Board Assessment}

Executive Directors commended the authorities for Afghanistan's continued satisfactory performance under the Poverty Reduction and Growth Facility (PRGF)-supported program, despite a difficult security environment. They emphasized that, to improve Afghanistan's sustainable growth and poverty alleviation prospects, the authorities need to accelerate structural reforms to enhance governance, overcome infrastructure bottlenecks, and promote private sector activities while reducing the government's involvement in the economy.

Directors noted the revenue shortfall that emerged in the third quarter of the current fiscal year, and stressed the need for revenue enhancing measures to move Afghanistan toward fiscal sustainability. They encouraged the authorities to muster political support to implement measures aimed at bolstering revenue collection, in particular by expanding the revenue base of medium and large tax payers.

Directors welcomed the progress made in strengthening expenditure control, and considered that continued efforts were needed to meet the government's medium-term objective of covering operating expenses from domestic revenue. Directors underscored the need to prioritize the use of scarce resources in line with Afghanistan's development objectives. They also highlighted the importance of clarifying the government's relations with state-owned enterprises with a view to stemming potential fiscal drains.

Directors welcomed the authorities' efforts to improve the effectiveness of monetary policy by broadening the central bank's policy instruments, especially in light of the recent rebound in inflation. In that context, they supported the increased reliance on capital notes and the development of a secondary market for these instruments. They recommended managing the volume of capital notes prudently in order to prevent unnecessary fluctuations in liquidity.

Directors commended the Da Afghanistan Bank (DAB) for the successful outcome of the special audit on the availability of foreign reserves. Looking forward, they encouraged the authorities to improve the DAB's accounting system.

Directors welcomed the measures recently taken by DAB to strengthen bank supervision and the regulatory framework for banks, as well as DAB's decision to proceed expeditiously on implementing changes to the minimum capital requirement and investment regulations for banks.

Directors noted that the current exchange rate regime had served Afghanistan well, and that the exchange rate level appeared to be broadly in line with fundamentals. They stressed the need to maintain a transparent and liberal trade regime to improve external competitiveness. In this regard, they welcomed the elimination of the discretionary preferential import tariff for selected businesses.

Directors welcomed the progress made toward completing Afghanistan's National Development Strategy. They noted that, to achieve maximum effectiveness of public investment, the 
authorities needed to align their sectoral strategies with the government's growth objectives, while taking proper account of the absorptive capacity of the economy. They also stressed the importance of securing debt relief agreements on comparable Paris Club-terms with all remaining creditors.

Directors noted the authorities' intention to link explicitly the disbursement of subsidies to the state-owned electricity company to progress in its restructuring. They indicated that addressing the shortage and high cost of electricity in Afghanistan will have a major positive impact on the business environment and the well-being of the population.

Directors stressed the need for improvements in Afghanistan's statistical database, in particular in the areas of the national accounts and the balance of payments. They encouraged the authorities to strengthen the Central Statistics Office in order to improve coordination among data providers.

Public Information Notices (PINs) form part of the IMF's efforts to promote transparency of the IMF's views and analysis of economic developments and policies. With the consent of the country (or countries) concerned, PINs are issued after Executive Board discussions of Article IV consultations with member countries, of its surveillance of developments at the regional level, of post-program monitoring, and of ex post assessments of member countries with longer-term program engagements. PINs are also issued after Executive Board discussions of general policy matters, unless otherwise decided by the Executive Board in a particular case. The staff report (use the free Adobe Acrobat Reader to view this pdf file) for the 2007 Article IV Consultation with the Islamic Republic of Afghanistan is also available. 
Islamic Republic of Afghanistan: Selected Economic Indicators, 2004/05-2007/08

(Quota: SDR 161.9 million)

(Population: 25.7 million; 2005/06)

(Per capita GDP: US\$250; 2005/06)

(Poverty rate: n.a.)

(Main export: carpets, US\$186 million; 2006/07)

\begin{tabular}{|c|c|c|c|c|}
\hline & $\frac{\text { Est. }}{2004 / 05}$ & $\frac{\text { Est. }}{2005 / 06}$ & $\begin{array}{r}\text { Est. } \\
2006 / 07\end{array}$ & $\begin{array}{r}\text { Projections } \\
2007 / 08 \\
\end{array}$ \\
\hline & \multicolumn{4}{|c|}{ (Annual percentage change; unless indicated) } \\
\hline \multicolumn{5}{|l|}{ Output and prices $1 /$} \\
\hline Real GDP & 9.4 & 16.4 & 6.1 & 13.5 \\
\hline Nominal GDP (in millions of Afghanis) & 258,468 & 321,939 & 351,771 & 436,646 \\
\hline Nominal GDP (in millions of U.S. dollars) & 5,402 & 6,483 & 7,048 & 8,719 \\
\hline Consumer prices (period average) $2 /$ & 13.2 & 12.3 & 5.1 & 9.8 \\
\hline Consumer prices (end of period) 2/ & 14.9 & 9.4 & 4.8 & 12.0 \\
\hline & \multicolumn{4}{|c|}{ (In percent of GDP) } \\
\hline \multicolumn{5}{|l|}{ Public finances } \\
\hline Operating revenue (including grants) & 10.7 & 11.6 & 13.6 & 13.6 \\
\hline Operating expenditure $3 /$ & 10.3 & 10.0 & 12.4 & 12.2 \\
\hline Operating budget balance (excluding grants) 3 / & -5.4 & -3.6 & -4.2 & -4.0 \\
\hline Operating budget balance (including grants) 3/ & 0.4 & 1.6 & 1.3 & 1.4 \\
\hline Core budget balance (including grants) & -1.4 & 1.0 & -3.1 & -2.9 \\
\hline & \multicolumn{4}{|c|}{ (Annual percentage change; unless otherwise indicated) } \\
\hline \multicolumn{5}{|l|}{ Monetary sector } \\
\hline Currency in circulation (year-to-date change) & 34.6 & 14.6 & 11.2 & 19.3 \\
\hline One-month capital note interest rate (end-period, in percent) 4/ & 5.0 & 6.5 & 7.6 & 10.5 \\
\hline & \multicolumn{4}{|c|}{ (In percent of GDP; unless otherwise indicated) } \\
\hline \multicolumn{5}{|l|}{ External sector $5 /$} \\
\hline Current account balance, excluding official transfers & -65.2 & -75.3 & -77.1 & -72.6 \\
\hline Current account balance, including official transfers & -4.4 & -2.8 & -6.3 & -1.4 \\
\hline Total external debt $6 /$ & 12.8 & 184.2 & 170.9 & 21.6 \\
\hline Gross reserves (in millions of U.S. dollars) & 1,283 & 1,662 & 2,064 & 2,335 \\
\hline In months of next year imports of goods and services $7 /$ & 6.7 & 7.7 & 9.3 & 9.4 \\
\hline \multicolumn{5}{|l|}{ Memorandum items: } \\
\hline Afghanis per U.S. dollar (period average) & 47.8 & 49.7 & 49.9 & $\cdots$ \\
\hline
\end{tabular}

Sources: Afghan authorities; and IMF staff estimates and projections.

$1 /$ National accounts numbers were revised to reflect the authorities' data, excluding the drug economy.

2/ For Kabul.

3/ Does not include core budget development spending and externally-financed development expenditures, which amounted to 9.2 percent of GDP and 55.4 percent of GDP, respectively, in 2006/07.

4/ The 2007/08 number is for January 1, 2008.

5 / Numbers have been revised as a result of more reliable data on public grants.

6/ After HIPC and MDRI relief as well as debt relief beyond HIPC relief from Paris Club creditors. Debt also includes obligations to the IMF. The debt stock includes the capitalization of interest to Paris Club creditors until completion point under the Enhanced HIPC Initiative. The large increase in the debt in 2005/06 reflects principally the recognition of Russia's claims (that were subsequently restructured), and the reconciliation of all March 2006 debt stocks for the HIPC Initiative.

7/ In months of imports of goods and services, excluding imports for reexports and duty free imports by donors. 
Press Release No. 08/25

International Monetary Fund

FOR IMMEDIATE RELEASE

Washington, D.C. 20431 USA

February 14, 2008

\section{IMF Executive Board Completes Third Review Under PRGF Arrangement with The Islamic Republic of Afghanistan and Approves US\$17.9 Million Disbursement}

The Executive Board of the International Monetary Fund (IMF) has completed the third review of The Islamic Republic of Afghanistan's performance under the economic program supported by the three-year Poverty Reduction and Growth Facility (PRGF) arrangement. The completion of the review allows for an immediate disbursement of SDR 11.3 million (about US\$17.9 million), which would bring total disbursements under the arrangement to SDR 47.1 million (about US\$74.5 million).

In completing the review, the Board also granted a waiver of non-observance of a structural performance criterion on submitting to parliament the core budget's audited financial statement for $2006 / 07$. The audited financial statement was submitted with a minor delay and no corrective action is required.

The PRGF arrangement for the Islamic Republic of Afghanistan was approved in June 2006 for a total of SDR 81.0 million (about US\$128 million) (see Press Release No. 06/144).

The PRGF is the IMF's concessional facility for low-income countries. PRGF-supported programs are based on country-owned poverty reduction strategies adopted in a participatory process involving civil society and development partners and articulated in a Poverty Reduction Strategy Paper (PRSP). This is intended to ensure that PRGF-supported programs are consistent with a comprehensive framework for macroeconomic, structural, and social policies to foster growth and reduce poverty. PRGF loans carry an annual interest rate of 0.5 percent and are repayable over 10 years with a 51/2-year grace period on principal payments.

Following the Executive Board's discussion, Mr. Murilo Portugal, Deputy Managing Director and Acting Chair, said:

"Despite a difficult security environment, Afghanistan continues to have a satisfactory performance under the Poverty Reduction and Growth Facility-supported program. Nevertheless, structural reforms need to be accelerated to support high growth and reduce poverty. 
"Real GDP growth is estimated to have moderated to 6 percent in 2006/07, but is projected to increase sharply in 2007/08, owing primarily to a rebound in agriculture. Year-on-year inflation was 17 percent in December 2007 on account of higher prices of imported fuel and foodstuffs. The revenue performance during the first half of 2007/08 was satisfactory, but revenue collection in the third quarter fell somewhat short of the indicative target for December 2007. However, prudent execution of the core operating budget permitted meeting the December 2007 indicative target on the operating budget deficit. The Afghani has appreciated by 1 percent against the U.S. dollar since end-December 2007, on account of increased sales of foreign exchange by Da Afghanistan Bank (DAB).

"Looking forward, the continued success of the program hinges on mustering political support for the revenue enhancing measures that are necessary to move Afghanistan toward fiscal sustainability. There is also a need to allocate adequate resources for infrastructure maintenance, and to clarify the government's relations with state-owned enterprises with a view to stem potential fiscal drains.

"As regards monetary policy, increased reliance on capital notes should enhance effectiveness. Managing the volume of capital notes prudently would be important in order to prevent unnecessary fluctuations in liquidity. It is also important to follow-up on Fund staff's recommendations to improve the accounting system of DAB. With regard to the banking sector, measures taken recently by DAB to strengthen bank supervision and the regulatory framework should help stem risks in this sector.

"The managed float regime in place has served Afghanistan well and the level of the exchange rate appears appropriate. In the future, improving competitiveness will require acceleration of structural reforms and further efforts at promoting a transparent and liberal trade regime. The authorities should also avoid further ad hoc changes to the tariff schedule. The authorities have made satisfactory progress toward completing their PRSP — the Afghanistan National Development Strategy. In the period ahead, they should align sector strategies with the growth objectives, while taking into account the economy's absorptive capacity.

"The intention to link explicitly the disbursement of subsidies to the state-owned electricity company to progress in its restructuring should provide momentum for much-needed reforms in this area. Redressing the shortage and high cost of electricity in Afghanistan would have a major, positive impact on the business environment and the well-being of the population. The authorities have launched a joint appeal with the World Food Program to distribute wheat to areas affected by shortages. Cash-transfers should be targeted to vulnerable households - sourced from the existing budget envelope - to mitigate the effect on the poor of rising wheat prices," Mr. Portugal said. 
Statement by Mr. Mohammed Daïri, Alternate Director for Islamic Republic of Afghanistan February 13, 2008

The authorities are grateful to the staff of the IMF and World Bank for their support of the ongoing comprehensive restructuring and stabilization efforts in Afghanistan. They wish, in particular, to thank Mr. Elhage and his team for the very useful dialogue and the excellent set of papers. The decision to go forward with debt relief under the HIPC-Initiative reflects the international community's strengthened commitment to supporting Afghanistan and has also boosted domestic support for meeting the challenges that lie ahead. My authorities are fully committed to achieving the MDGs and laying the foundations of sustainable high growth, and express their deep appreciation to the international community for its generous financial and technical support.

Despite the exceptionally difficult circumstances, the authorities have made significant progress under the economic program supported by the PRGF arrangement. Economic performance has been strong despite the heightened security concerns. Average real GDP growth has been around 15 percent per year in the last five years, with various sectors exhibiting good performance, notwithstanding the adverse effects of the 2006/07 drought on agricultural production. Inflation has been moderate, with the recent increase in 2007/08 largely attributable to the sharp increases in imported fuel and foodstuff. While growth in opium production continues to have a deleterious impact by constraining the expansion of the licit economy and access to formal tax bases, the impact on competitiveness of traditional exports may have been contained, as suggested by the performance of traditional exports. With sustained donor support, the official reserve position has strengthened to a level equivalent to more than 9 months of imports. The fiscal position has improved with strong revenue efforts and prudent expenditure policy, contributing to a reduction in the core operating budget deficit (excluding grants) since 2004/05. The budgetary process and revenue efforts have been strengthened significantly through increasingly incorporating a medium-term outlook to budget preparation, administrative capacity building, and tax reforms. All quantitative performance criteria for the Third Review have been met, prior actions have been carried out, and structural conditionality has been by and large fulfilled. The small deviations from the indicative floor for revenue and the ceiling for currency in circulation for the third quarter were due in part to exogenous or temporary factors, and remedial measures are being implemented as indicated in the staff's supplement.

The monetary policy framework has been strengthened and the market-determined exchange rate is in line with fundamentals. As noted in the Special Issues paper, some deficiencies in the main instrument of market intervention (open-market operations) have been addressed through improvement in the auction procedures. The volume of capital notes and their maturity structure has been increased, including the introduction of 182-day notes in 2007. The authorities recognize the need to deepen further the market for capital notes by increasing systematically the volume of primary auctions and further developing the secondary market for these instruments. Coordination between the Central Bank and the 
Ministry of Finance is also in need of improvement to allow for more informed and accurate liquidity forecasts.

Notwithstanding the capacity constraints, banking supervision and regulation, including on $\mathrm{AML} / \mathrm{CFT}$, is improving at an impressive rate, which is important given the size of the informal markets. Significant progress has been made in putting the supervisory mechanisms in place, including compliance with many Basel Core Principles. As noted in the Special Issues paper, the welcome rapid expansion in the private banking sector has resulted in some supervisory and regulatory challenges, including ensuring capital adequacy and sound risk management practices in some cases. In order to address these challenges, the authorities have stopped licensing new branches for those banks with an unfavorable (CAMEL) rating and have restricted credit growth by such banks to 5 percent per quarter. Efforts are being made to improve risk-based supervision and banking supervision enforcement. The authorities have already strengthened the legal framework by issuing regulations on credit standards and credit monitoring process, as well as by setting limits on loan concentration. Progress has been made in the restructuring of the two state-owned banks (Bank Pashtany and Bank Millie), and the authorities have prohibited lending by those banks to state-owned enterprises that do not have audited balance sheets and Cabinet-approved restructuring plans.

As reiterated in their LOI and MEFP, the authorities are committed to important reforms in many areas, including increasing transparency and reducing government involvement in the petroleum sector. Implementation of some of the more complex and multifaceted structural reforms has run into delays due to the need to engender the necessary political consensus and ensure adequate coordination with the Afghan National Development Strategy (ANDS), which is under preparation. The authorities have implemented, although with some delay, the measures covered by the structural benchmarks for end-November 2007 and, as indicated in the staff's statement, are diligently working to implement the remaining reforms. In particular, they have made the legislative changes to eliminate the discretionary application of the 1 percent import tariff rate on raw materials and other intermediate inputs, and are working to complete the preparation of the comprehensive restructuring and privatization of government enterprises that are not covered by the SOE law. In this latter regard, they are actively examining options on how to deal with the national airline Ariana in a way that would safeguard public finances as well as state-owned banks against drains or contingent liabilities that could result from Ariana's dire financial condition. The authorities aim at obtaining Cabinet approval of this package by end-March 2008, as indicated in the MEFP.

With continued donor support and debt relief and, in the absence of further deterioration in the security situation, the medium-term prospects appear favorable. The authorities are fully aware that the ultimate success of the ongoing program and the restructuring and poverty reduction efforts depend on their continued commitment to timely implementation of their reforms. As detailed in the MEFP and delineated in the structural benchmarks under the Fourth and subsequent PRGF reviews, the authorities remain committed to continued fiscal discipline toward supporting the ANDS priorities and gradually reducing reliance on donor support. Toward these ends, the reform effort will focus on better defining the role of government in the economy, fighting corruption, improving the legal infrastructure to foster private sector development, strengthening administrative capacity, and liberalizing trade. The 
authorities recognize that there will be considerable challenges in meeting upcoming revenue targets, and are committed to taking extra steps to continue to improve revenue collection.

As the PRSP emphasizes, development of human capital remains a challenge, even though the return of many skilled expatriates has already boosted entrepreneurship. While the authorities are firmly determined to deliver on their commitments to achieve their objectives, further technical assistance by the IMF and other donors will continue to be critically important in the period ahead, in particular in view of the limited administrative capacity and security challenges. The authorities are striving to meet the completion point triggers for the HIPC-Initiative, which, along with MDRI and continued donor support, is critical to reducing the debt burden to sustainable levels. In this regard, as underlined in the PRSP, the ANDS document preparation is at an advanced stage, targeted for submission to the Board of the IMF and the World Bank by end-March 2008.

Against this background, the authorities believe that there is considerable reform momentum and that the program is on track. They thank the Executive Board, management, and staff for their invaluable support and look forward to the completion of the Third Review under the PRGF-supported program. 